


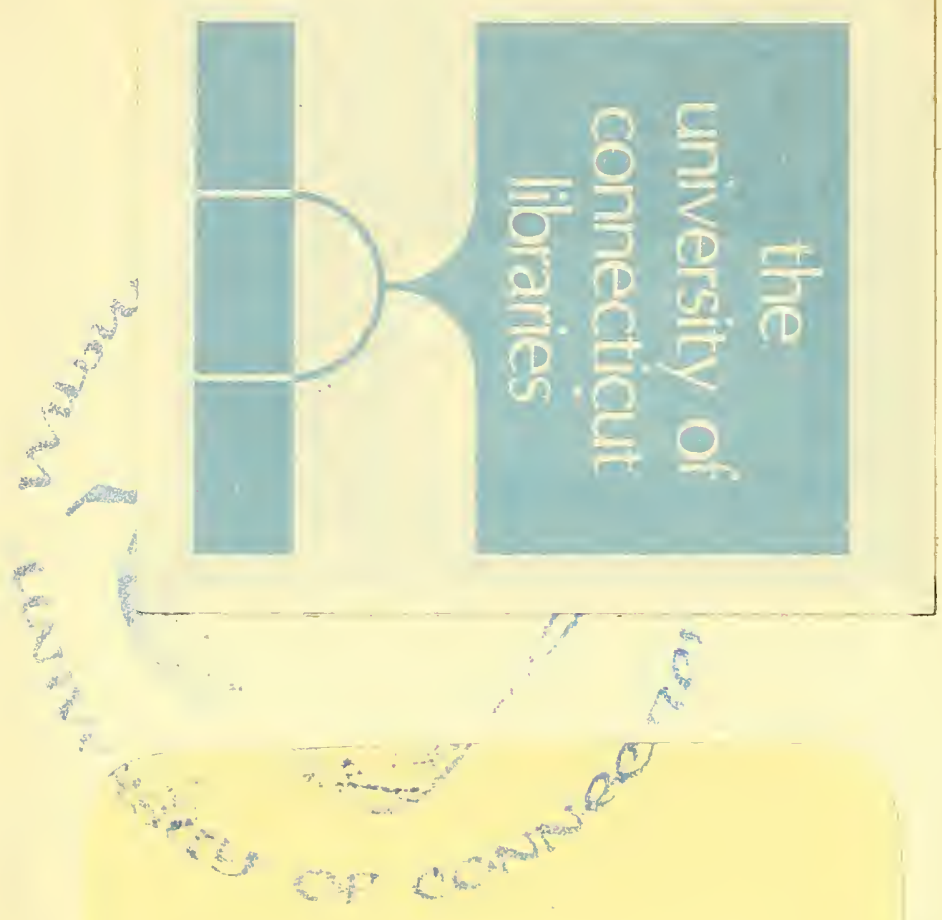

hbl, stx

SD144A12L8

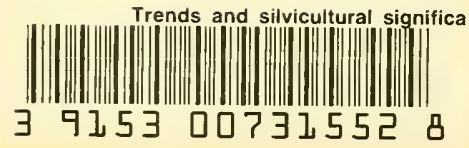


Digitized by the Internet Archive in 2011 with funding from

Boston Library Consortium Member Libraries 





\title{
TRENDS AND SILVICULTURAL SIGNIFICANCE \\ OF UPLAND FOREST SUCCESSIONS IN SOUTHERN NEW ENGLAND
}

\author{
BY \\ HAROLD J. LUTZ \\ Research Fellow, Yale University
}

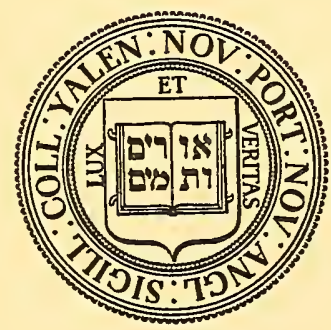

NEW HAVEN

Yale University

I 928 


$$
\begin{aligned}
& \text { SD } \\
& 144 \\
& A 12 \\
& \angle 8
\end{aligned}
$$




\section{CONTENTS}

Page

FOREWORD

INTRODUCTION 9

DEFINITIONS OF ECOLOGICAL TERMS IO

THE UPLAND FOREST ASSOCIATIONS II

METHODS USED IN THE INVESTIGATION I2

THE RED CEDAR-GRAY BIRCH ASSOCIATION I4

General characteristics $\quad$ I4

Taxonomic features $\quad$ I4

Distribution $\quad$ I5

Successional relations $\quad$ I6

Anthropeic influences $\quad$ I6

Illustrative examples $\quad$ I8

THE HARDWOOD ASSOCIATION 19

General characteristics $\quad$ I9

Taxonomic features $\quad$ I9

Distribution $\quad 20$

Successional relations $\quad 2$ I

Anthropeic influences $\quad 2 \mathrm{I}$

Illustrative examples $\quad 22$

THE HEMLOCK-HARDWOOD ASSOCIATION 25

$\begin{array}{ll}\text { General characteristics } & 25\end{array}$

Taxonomic features $\quad: 26$

Distribution $\quad 26$

Ecological relations in hemlock reproduction $\quad 26$

Successional relations $\quad 30$

The climatic climax association $\quad 30$

Anthropeic influences $\quad 32$

Illustrative examples $\quad 33$

Retrogressive succession $\quad 33$

The climatic climax $\quad 34$ 


\section{CONTENTS}

SUMMARY OF STRUCTURAL AND SUCCESSIONAL RELATIONS

General structure of the upland forest associations

Basal area in relation to successional development

Successional relations of upland forest associations

SILVICULTURAL SIGNIFICANCE OF THE UPLAND FOREST ASSOCIATIONS

Red cedar-gray birch association

Hardwood association

Hemlock-hardwood association

The "ideal" forest association

SILVICULTURAL POLICY AND PRACTICE

Red cedar-gray birch association

Hardwood association

Hemlock-hardwood association

LIST OF SPECIES WITH THEIR FREQUENCY OF OCCURRENCE

TABLES

REFERENCES 


\section{ILLUSTRATIONS}

I. Red cedar coming in on meadow

2. Red cedar coming in on pasture

3. Typical red cedar-gray birch association

4. Pure stand of gray birch

5. A red cedar stand

6. Transition from red cedar-gray birch to hardwood association

7. Replacement of red cedar by hardwoods

8. Dominant hardwoods over dead red cedar

9. Hardwood stand that initiated forest succession on abandoned field

Io. An even aged stand of young hardwoods

Ir. A mature hardwood association

I2. Typical hardwood association

“ $\quad$ I 5

" 16

" 17

" 20

" $2 \mathrm{I}$

" 24

" 25

I3. Chart quadrat showing relation of shade to hemlock reproduction

I4. Chart quadrat showing relation of shade to hemlock reproduction

I 5. Hardwood stand with hemlock under story

I6. Reproduction of hemlock under oak crowns

facing 30

" 3 I

I7. Location of shaded and exposed strips examined in hemlock reproduction studies

I 8. Virgin forest at Colebrook, Connecticut

I9. Group of hemlock reproduction

“ 3 I

" 32

“ 33

20. Inferior hardwood stand following clear cutting in climax forest

2 г. Hardwood stand resulting from clear cutting a hemlockhardwood stand

22. Graphic characterization of the forest associations

23. Development of secondary forest associations

24. Effect of disturbances on forest succession

25. Hemlock-hardwood stand

26. Typical hemlock-hardwood stand

27. A stand in which hemlock predominates 



\section{FOREWORD}

$7 \mathrm{HE}$ field studies on which this bulletin is based were made during

1 1926 and 1927 while the writer was a Research Fellow in the School of Forestry, Yale University.

The author wishes to acknowledge his indebtedness to Ralph C. Hawley, Professor of Forestry, Yale University, and to Dr. George E. Nichols, Professor of Botany, Yale University, under whose joint direction this work was carried out, for their many helpful suggestions and aid, both in the field work and in the preparation of the manuscript.

Most of the field work was done on lands owned by the New Haven Water Company, which are used by the Yale School of Forestry for investigative purposes. 



\section{TRENDS AND SILVICULTURAL SIGNIFICANCE OF UPLAND FOREST SUCCESSIONS IN SOUTHERN NEW ENGLAND}

\section{INTRODUCTION}

$7 \mathrm{HE}$ problems encountered in the silvicultural treatment of southern 1 New England forests are many. They result largely from the extremely diverse and complex conditions under which the forest is developed. Due to the glaciated nature of the region the soil character changes radically within relatively short distances. With changes in soil from place to place come minor changes of forest composition. One of the chief reasons for the problems which the silviculturalist encounters in this region is the large number of species which make up the stands. There are approximately thirty commercially important forest trees in southern New England.

The complicated character of the stands makes a knowledge of their development indispensable to silvicultural practice. It is well known that forest vegetation is continually undergoing change; it is unstable. This means that it must be studied not as a static but as a dynamic entity; in other words, it must be considered from the point of view of its successional development.

The importance of a knowledge of forest succession is readily apparent when it is considered that all silvicultural practice, including forest protection, induces successional change. The amount of change produced is dependent, of course, on the magnitude of the disturbance brought about by the silvicultural operations. Experience has demonstrated that, after all, silviculture which recognizes the tendencies of nature is the best silviculture. The farther the silviculturalist departs from natural tendencies the greater the chance of producing conditions which will eventually prove inimical, if not disastrous, to successful crop production. On the other hand, the application in practice of the facts and principles of forest succession may often be made with little or no extra initial cost and with considerable ultimate gain. 


\section{UPLAND FOREST SUCCESSIONS}

The object of the present study is to determine the trends and silvicultural significance of the upland forest successions in southern New England.

\section{DEFINITIONS OF ECOLOGICAL TERMS}

GINCE there is some diversity in usage of ecological terms by various $\mathcal{N}$ authors, it may be desirable to define those used in this report. The terminology adopted is that of Nichols (1923).

Association - a plant community characterized by its essentially homogeneous physiognomy, ecological structure, and floristic composition, at least in regard to dominant species.

Stand-used in the same sense as the term association, with reference to a particular piece of vegetation. Christopherson (1925).

Plant community-any group of plants growing together.

Succession-the replacement, in the course of time, of one plant community by another. Successions may be progressive (toward a climax) or retrogressive (toward a lower developmental stage). Successions may be primary (starting on bare soil or rock) or secondary (starting on soil or rock which has previously supported plant growth).

Climax-a stage in vegetational development beyond which, practically speaking, there is no further developmental (or successional) change. Two types of climax are distinguished:

(a) climatic climax-the most advanced type of vegetation that is capable of development under the climatic conditions which characterize a climatic region.

(b) physiographic climax-the most advanced type of vegetation capable of development in any physiographically uniform area. In physiographically favorable areas the physiographic climax corresponds with the climatic climax of the region; in physiographically unfavorable areas it represents a lower stage of development than the climatic climax.

Abundance-a term used to designate the relative numbers of plants or species which enter into the stand.

Frequency - the degree of uniformity with which the plants of individual species are distributed throughout the stand. 


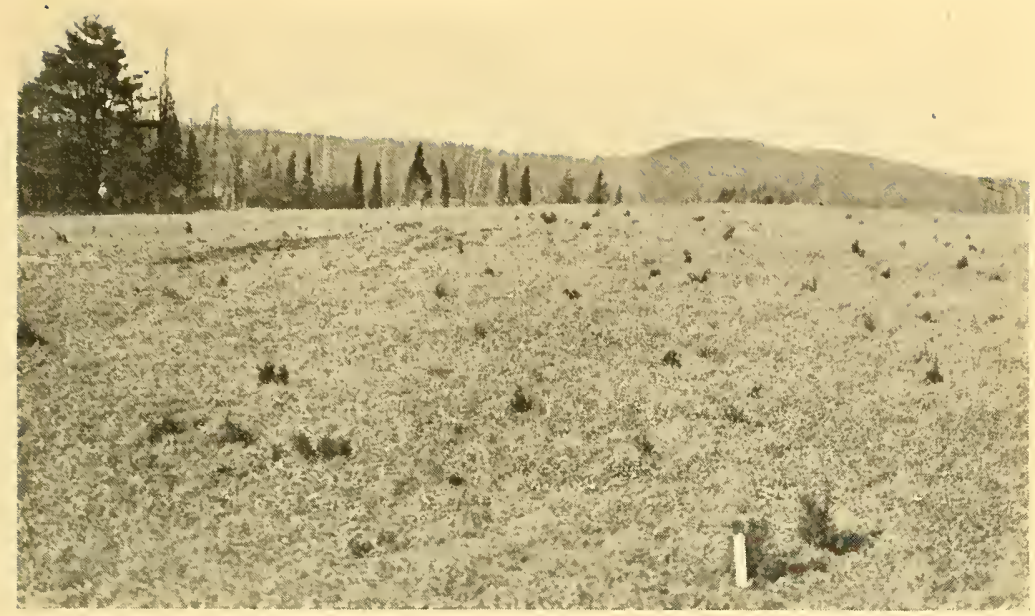

Fig. I. Red cedar coming in on an abandoned meadow.

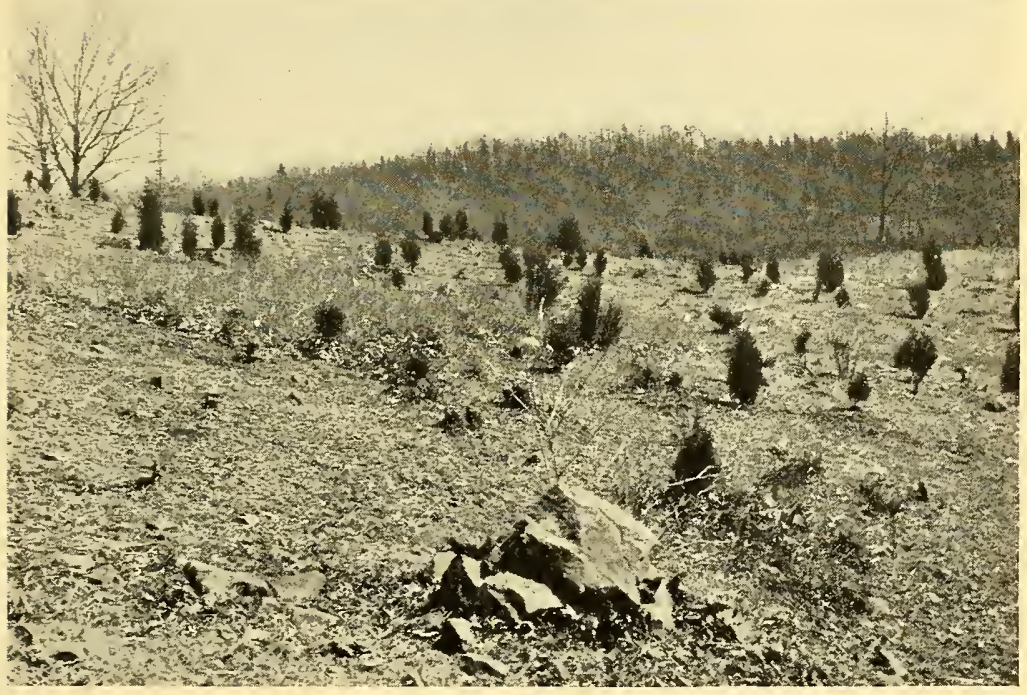

Fig. 2. Red cedar coming in on an old pasture. Browsing by grazing animals restricts the establishment of hardwoods. 


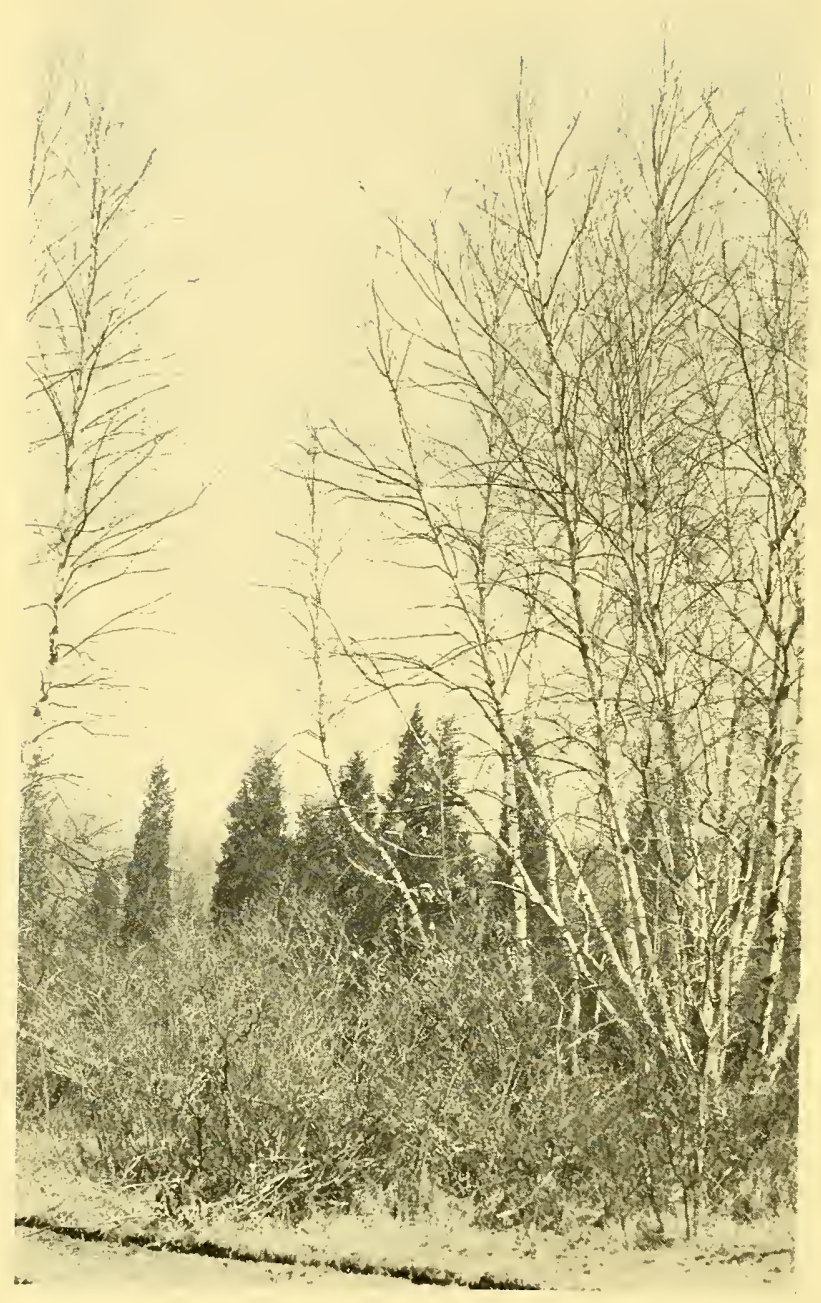

Fig. 3. A typical red cedar-gray birch association which originated on an old field. The dense shrubby growth is principally Rhus copallina and Myrica carolinensis. 


\section{THE UPLAND FOREST ASSOCIATIONS}

$7 \mathrm{HE}$ amount of new land in the process of formation in southern New 1 England is negligible. Areas of this description are confined largely to talus slopes and alluvial and marine deposits. The primary successions of these areas are of so little importance in forestry that they were not studied.

All the successions studied were of a secondary character; they originated on land which formerly supported tree growth, in most cases the climatic climax of the region. The upland areas which formerly supported a physiographic climax are of small importance in present day forestry. The white pine association, which may have been a physiographic climax, occurred principally on the sandy soils along some of the large rivers. Bidwell and Falconer (1925) indicate that the favorable situation of many such areas along the larger rivers, together with absence of large amounts of rock in the sandy soil, led to their early use for agriculture. For the most part they are in agricultural use to-day. Xerophytic areas which supported physiographic climaxes were not studied since they are of little importance from the standpoint of forestry. The swamp association, which is a physiographic climax, has only a limited distribution in southern New England. Areas occupied by this association, in contrast to uplands, are for the most part classed as lowlands and accordingly are not included in the present study of upland successions. The planted white pine and red pine associations established in southern New England, chiefly within the last twenty years, were not studied in the present work.

The successions with which this study is concerned occur on three broad classes of land, distinguished by the magnitude of the disturbance to which the areas have been subjected. The classes are: (a) "old field" areas from which the former forest stand at one time or another has been wholly excluded by agricultural use; (b) areas which have been burned, cut over, grazed, or otherwise severely disturbed, but not to the exclusion of all former forest growth; and (c) areas which have been only slightly disturbed.

The following three upland forest associations have been distinguished: (a) the red cedar-gray birch association; (b) the hardwood association; and (c) the hemlock-hardwood association. These associations are arranged in their successional order, from the more primitive to the more advanced stages. 


\section{UPLAND FOREST SUCCESSIONS}

The relative amount of area occupied in this region by forest associations is estimated to be as follows (in per cent of the total forested area of southern New England) : red cedar-gray birch association, 20; hardwood association, 70; hemlock-hardwood association, 5; and swamp association, 5 .

While practically all the forest vegetation can be quite definitely assigned to one of these associations, it should be kept in mind that all degrees of blending are found in nature. In progressive succession the changes which are brought about by the vegetation are usually slow. Consequently, almost imperceptible transitions are met with from the more primitive to the more advanced stages. Retrogressive successions, on the other hand, tend to be very distinct and rapid, especially if they owe their origin to severe disturbances.

\section{METHODS USED IN THE INVESTIGATION}

$7 \mathrm{HE}$ principal method used was the so-called method of alternating 1 areas. In applying this method the progress of succession, as developed on different areas, is largely deduced from the comparative study of different stages from the earliest forest association to the climatic climax of the region. These various individual views of the vegetation are then fitted together to form as complete a developmental picture as possible. Clements (1916).

This method was reinforced by both qualitative and quantitative measurements of the composition and structure of the various associations. In these measurements both quadrats and transects were used. The size of most of the quadrats was about one-tenth of an acre. This size was not adhered to strictly, but was varied as necessity demanded. Likewise, no set rules were followed in the matter of shape of quadrats. In all cases the quadrats were laid out with a standard compass and a steel tape. It was found that stringing the quadrats greatly facilitated accurate counting of the plants present. Quadrats were charted only when necessary to depict the structure of the vegetation or to illustrate certain conditions or tendencies which could not be shown otherwise.

This investigation was concerned primarily with determining the broad successional tendencies manifest in the forest, so it was not considered necessary to analyze the edaphic factors of site on the various quadrats through the use of instruments. Such edaphic factors as are amenable to 


\section{METHODS}

ocular observation were noted and their effect on the vegetation arrived at by inference.

In the analysis of the various associations three vegetational layers were arbitrarily recognized:

(a) vegetation up to six feet in height;

(b) vegetation six to fifteen feet in height;

(c) vegetation over fifteen feet in height.

Diameter breast high and crown classification was secured for all trees over fifteen feet in height. The crown classification used was the one favored by the Society of American Foresters (1917). Average ages and heights were secured either by actually felling individual trees or by the use of an increment borer and hypsometer.

The criterion of actual dominance used was the total basal area per acre of the trees over fifteen feet in height and the criterion of potential dominance or successional tendency was the numerical strength of the tree species in the two lower layers of vegetation. For example, hardwood species may make up practically the entire basal area of a stand in which the young growth less than fifteen feet in height is essentially pure hemlock. In such a stand the hardwoods are dominant and the hemlock is said to possess potential dominance since it indicates the successional trend. Height growth and persistence in its relation to dominance were also taken into account.

The frequency or degree of uniformity with which individual species are distributed throughout a stand (Gleason, 1920) was expressed in five degrees :

\begin{tabular}{|cc|}
\hline Frequency index & Per cent frequency \\
$\mathbf{I}$ & 0 to 20 \\
$\mathbf{2}$ & 20 to 40 \\
3 & 40 to 60 \\
4 & 60 to 80 \\
5 & 80 to 100 \\
\hline
\end{tabular}

This method of expressing frequency is simple and easy to apply. The differences indicated by the various indices are readily recognizable in the field. The frequency criterion was applied only to the lowest forest layer. 


\section{UPLAND FOREST SUCCESSIONS}

For the purpose of classifying sites in terms of forest growth a system was used based on the actual or estimated height of the dominant trees at eighty years of age. For the sake of convenience numerals have been used. to designate these site classes as follows:

\begin{tabular}{|cc|}
\hline Height in feet at 80 years & Site class \\
90 & I \\
80 & II \\
70 & III \\
60 & IV \\
50 & V \\
\hline
\end{tabular}

Photography was used to supplement charts and quadrat studies in portraying certain features of the associations.

\section{THE RED CEDAR-GRAY BIRCH ASSOCIATION}

\section{General Characteristics}

7 HIS association is xerophytic in character, as indicated by the deep1 rooted habit of the dominant tree species and the presence of species which are generally recognized as xerophytes. The appearance of this association is that of low, open, scrubby woodland. It is commonly designated "old field" type, since it usually originates on abandoned agricultural land.

\section{TAXoNomic Features}

There is considerable variation as regards composition. While the typical red cedar-gray birch association comprises a mixture of the two species, either of these may occur in pure stands. The latter condition often exists during the early periods of development.

The composition of the association is dependent to a large extent on the character of the seed bed prevailing at the time the association originates. Hawes and Hawley (I909) have pointed out that gray birch is a species which requires bare soil for a seed bed, while red cedar can start well under more adverse conditions, even under thick sod. This difference in the habits of the two species may explain their occurrence in pure stands such 


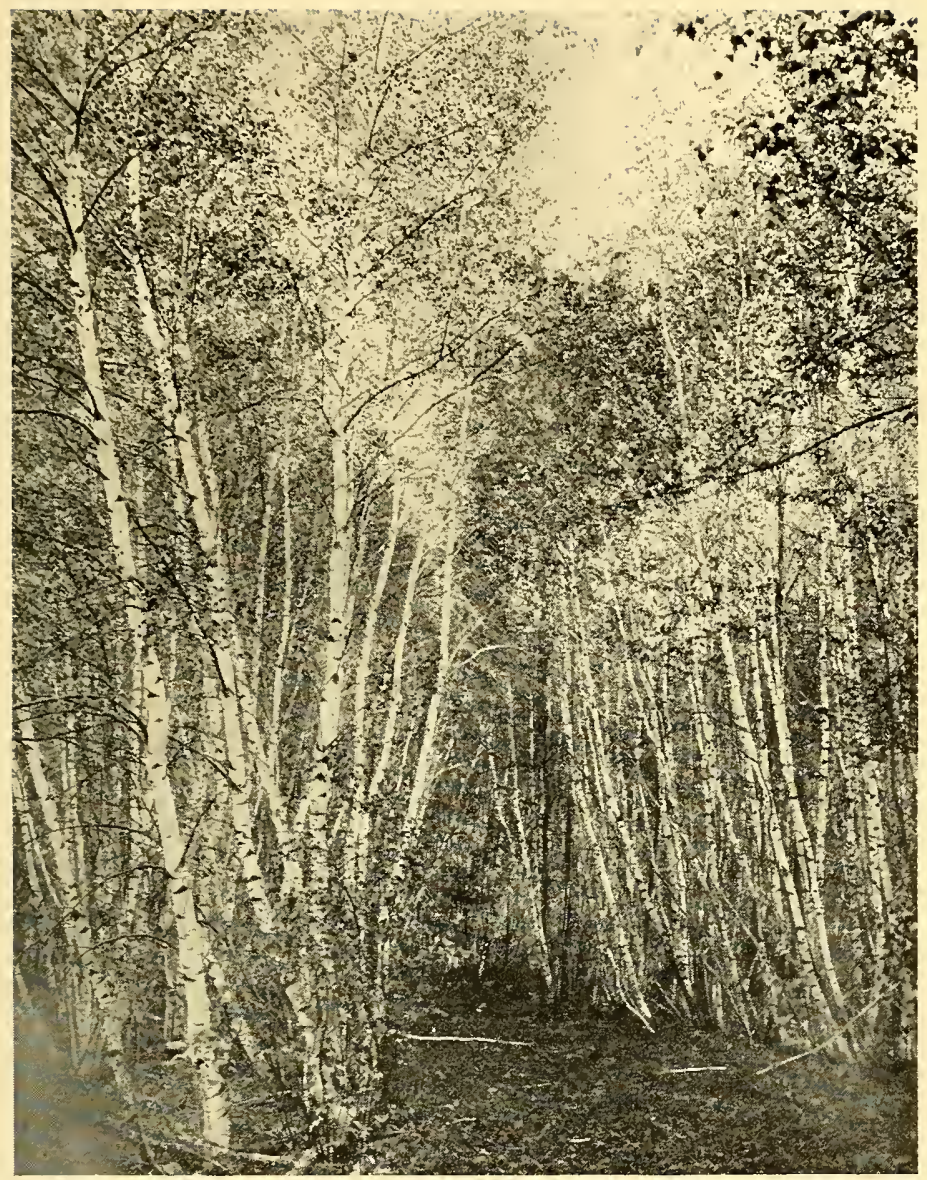

Photo by Dr. G. E. Nichols.

Fig. 4. A pure stand of gray birch which originated on an old field that was cultivated prior to abandonment. 


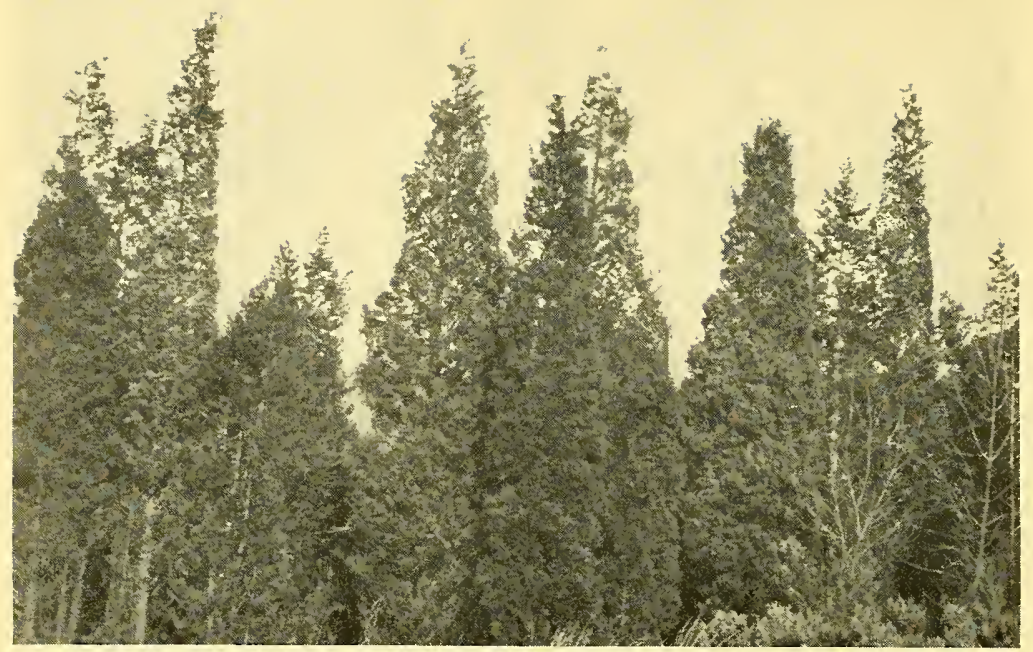

Fig. 5. A red cedar stand which originated on an abandoned pasture. Hardwoods are rapidly becoming established in this stand.

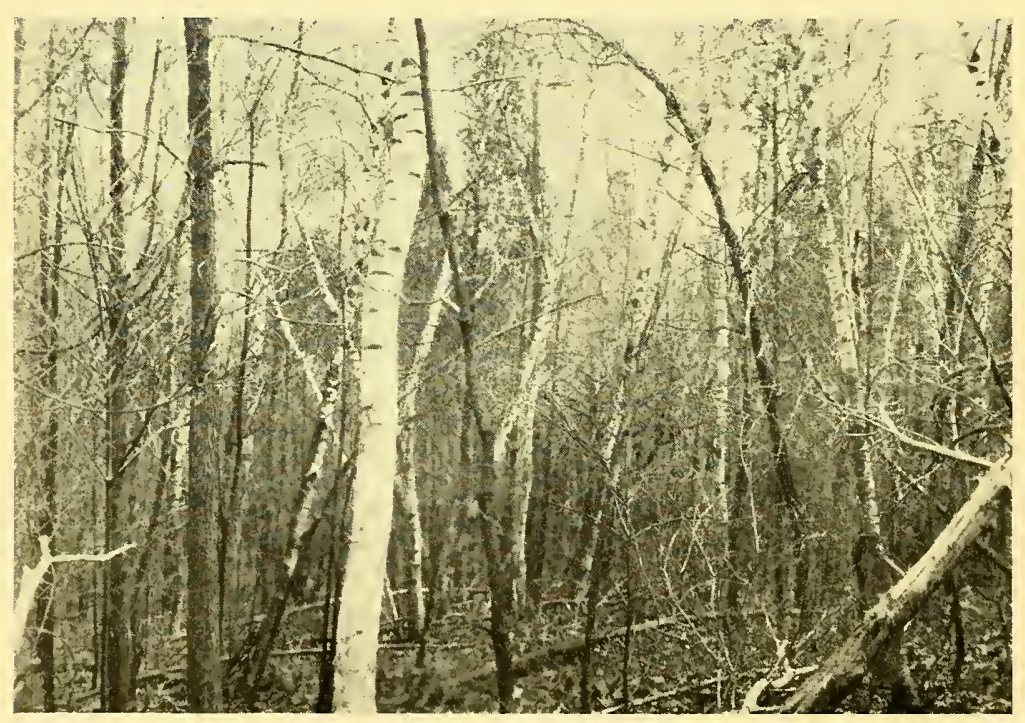

Fig. 6. A stand which illustrates the successional development from the red cedar-gray birch stage to the hardwood stage. Naltby Tract. New Haven Water Company. 
as those shown in Figures 4 and 5 . Fields which are abandoned as cultivated or plowed land come into gray birch, and abandoned pastures or meadows are more likely to become stocked with red cedar.

In addition to the character species, red cedar and gray birch, other species such as red maple, black birch, and dogwood may occur as scattered individuals. The number of individuals of these latter species depends on the age of the stand and the quality of the site. During early periods of development, hardwoods other than gray birch are scarce. As the association becomes older, hardwoods increase in numbers, at first light-seeded and later heavy-seeded species. Due to the less favorable soil conditions, the stands on poor sites have fewer hardwoods at a given age than the stands on better sites. The hardwoods usually assume the limby form of open grown trees, since they have almost unrestricted lateral development. A dense growth of shrubs such as Juniperus communis, Myrica carolinensis, Rhus copallina, Rhus glabra, and Rosa humilis often occurs in the open spaces between the trees. Such characteristic species as Andropogon scoparius, Rumex acetosella, Hieracium spp., Verbascum thapsus, and Solidago $s p p$. are usually found forming a part of the ground cover. Figures $I$ to 5 illustrate the various developmental stages in this association.

\section{DisTribution}

At present this association is widely distributed in southern New England, being found on all upland sites.

The bulk of the abandoned farm land falls into site classes somewhat better than the average for all forest land in the region. However, selection of land for agricultural use was based more on its accessibility and freedom from rock than on its potential productivity. Thus, much exceedingly poor land was taken up because it happened to lie adjacent to an owner's holdings or because it was easily tilled, due to the absence of large boulders. Exceedingly rocky, inaccessible land was more often left in forest, even if it had a richer soil.

In general, the red cedar-gray birch association occurs on land which is relatively low in organic matter and more or less exposed to the action of sun and wind. There is practically no humus layer in young stands. As the stands become older, the soil organic matter increases. With this increase comes greater microbiological activity and greater water-holding capacity. Earthworms and higher forms of animal life work the soil over, carrying organic matter down into the ground and bringing mineral soil up to the 


\section{UPLAND FOREST SUCCESSIONS}

surface. The roots of the vegetation also have an important influence. They penetrate the soil in all directions and after death the canals left by their decay assist aëration and serve as channels to conduct water into the ground. Through these processes the soil gradually improves in tilth, waterholding capacity, and available plant food. Indirect effects of trees, such as shade, also have a beneficial influence. As the stand closes, shade conditions become favorable enough so that mesophytic hardwoods creep in under the protection offered from excessive heat and transpiration. Thus, the association serves as a nurse crop for the seedlings of the more advanced hardwood stage.

\section{Successional Relations}

As already noted, the first tree growth to come in on abandoned fields in southern New England is usually the red cedar-gray birch association. In exceptional cases, however, this stage may be omitted entirely, and an association of hardwoods may initiate the succession. Such a situation sometimes results when favorable soil conditions are coupled with an abundant seed supply of hardwood species other than gray birch (Fig. 9).

The normal destiny of the red cedar-gray birch association is succession toward the hardwood association (Fig. 23). The rate of successional change is largely dependent on soil conditions, progressive succession being more rapid on good sites than on poor ones. It appears that the higher the percentage of gray birch in the association, the faster the succession will move. Gray birch stands usually deteriorate between thirty to sixty years old. On the better sites red cedar is usually overtopped and dies when it is sixty to eighty years old. Both the red cedar and gray birch are unable to endure suppression for any considerable length of time. If not suppressed by hardwoods, red cedar may live to be much older than eighty years, since it is inherently a fairly long-lived species. Gray birch, on the other hand, is inherently short-lived and dies between thirty to sixty years old even if it is not suppressed.

\section{Anthropeic Influences}

The influence of man is strongly manifested in this association. Not only is its origin directly or indirectly traceable to human influence, but the disturbances within the association after its establishment are due to cutting, fire, or grazing. The results of cutting depend on the severity of the operation and on the composition of the stand at the time of cutting. Clear 


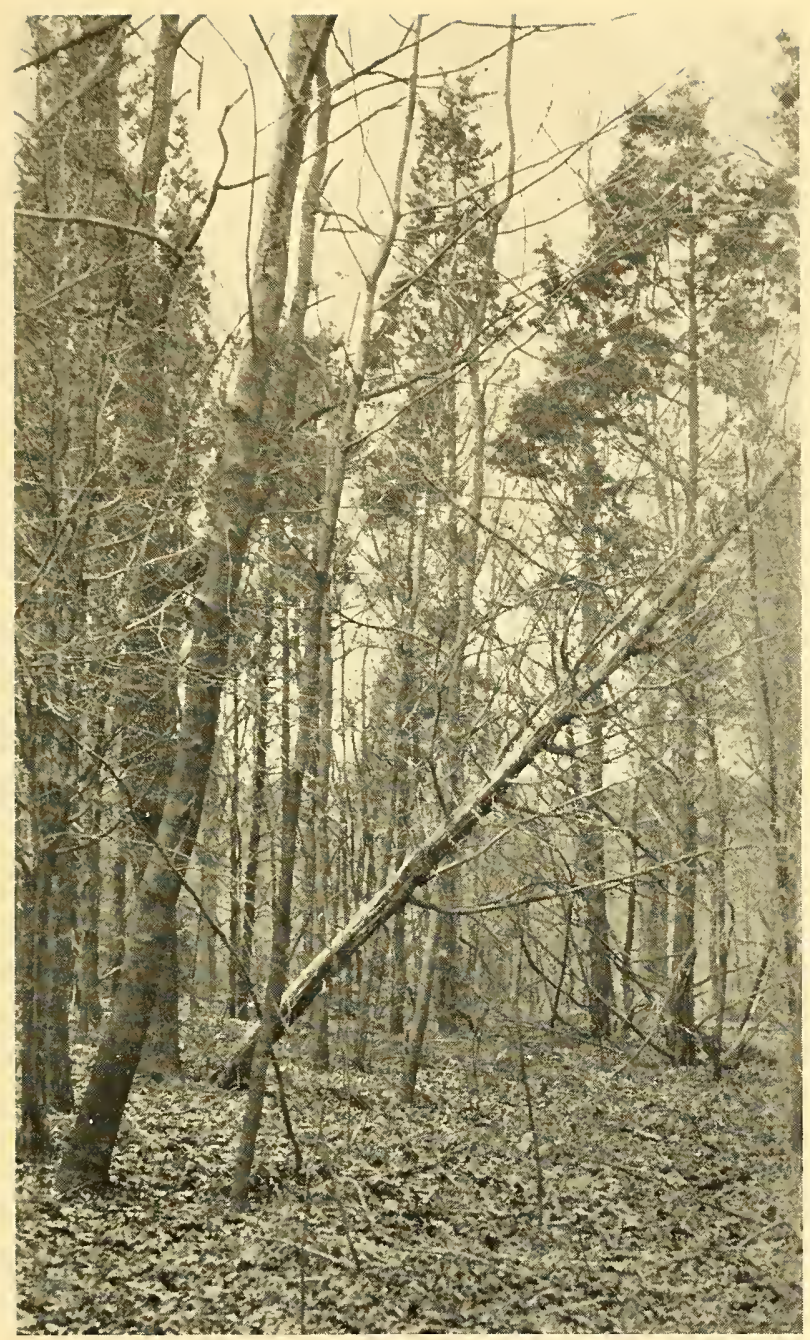

Fig. 7. A transitional stage in which the red cedar is dying and being replaced by hardwoods. 


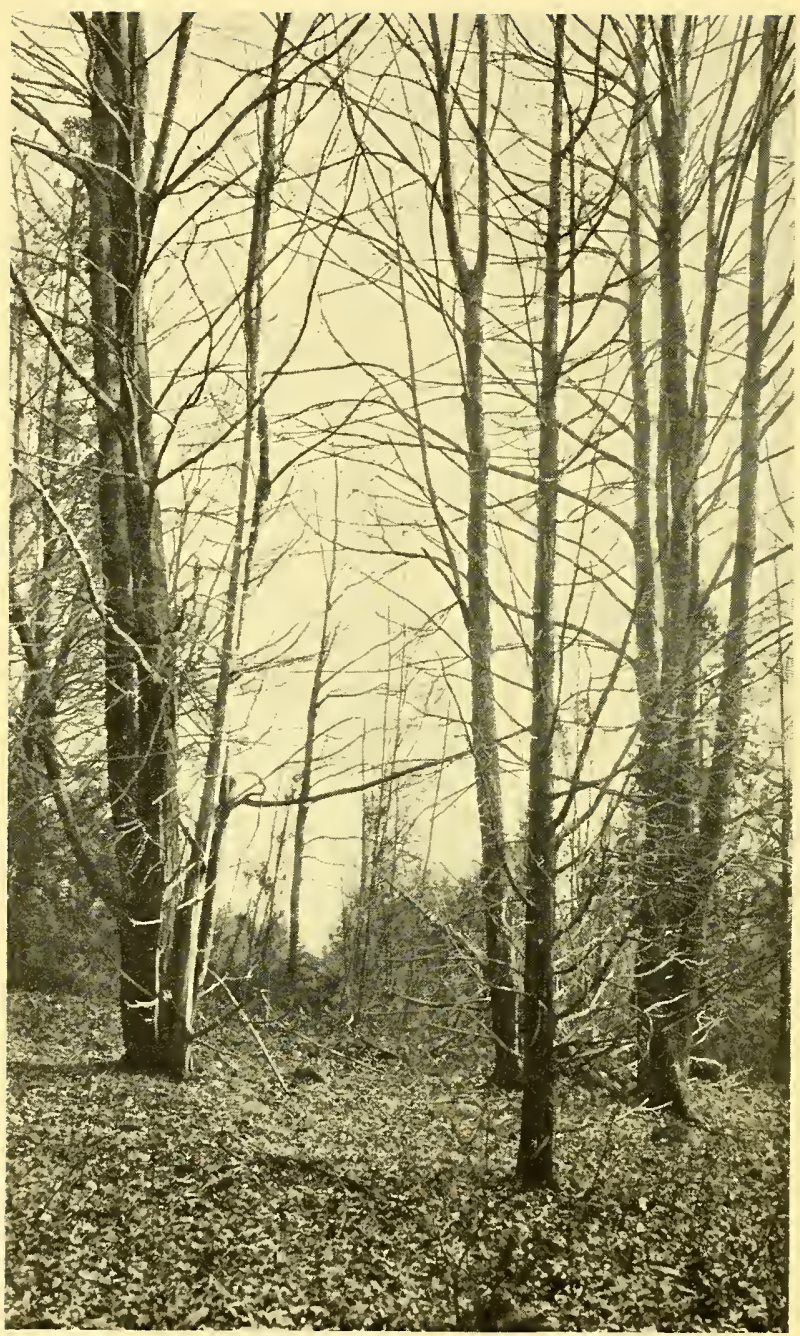

Fig. 8. A stand in which the hardwoods have gained almost complete dominance. Dead red cedar trees may be seen standing and down. 
cutting in a stand predominantly red cedar will result in serious deterioration of site, since grass and undesirable shrubs quickly become established. In a stand predominantly gray birch the result of the same operation will be quite different. The great sprouting ability of the birch insures the quick reëstablishment of a stand similar to the one removed. In this case little or no deterioration will result. The effect of light cuttings is not wholly clear, but indications are that they often result in retrogressive tendencies. In any case, deterioration is most marked on the poor sites and least marked on the better ones. This circumstance, which is observed in all associations, may be explained by the fact that on poor sites conditions for the growth of forest vegetation are precarious. The ecological margin of safety, so to speak, is narrow. Disturbances, even if slight, result in the introduction of so many limiting factors that a marked change in vegetation takes place. A good site, on the other hand, can suffer the same disturbance and show far less change, since its ecological margin of safety is much wider.

Fires are highly destructive to red cedar, as was pointed out by Harper (I9I2). Its thin, shredded bark, highly inflammable wood and foliage, and low branching habit all conspire to make it extremely susceptible. The damage to gray birch is not so severe or lasting, since its sprouting ability enables it to recover quickly. Fires in this association, as in others, are injurious not only to the tree growth itself but also to the soil. The soil organic matter is burned and the flora and fauna of the soil consequently change. Some of the species are driven out and others are greatly reduced in numbers. The soil becomes compacted and its water-holding capacity diminishes. Fires arrest the progressive development of the stand and cause postponement of the establishment of the more advanced hardwood stage.

Excessive grazing leads to pure red cedar stands and arrested development of the association. This result is accomplished by the selective grazing of stock, which browse on the young hardwoods but do not injure the red cedar. A dense growth of undesirable shrubs often follows heavy grazing. These shrubs may occupy the area so completely that hardwood seedlings are very slow in becoming established. While the question is still an open one, there is some evidence to indicate that the shrubby growth comes in while grazing is still in progress and not after it has been stopped. Indications are that the trampling of stock results in exposure of mineral soil which forms a favorable seed bed for the shrubs. With the increase of shrubby growth, grazing becomes progressively poorer to a point where it 
is no longer profitable and may be abandoned. A further undesirable effect of heavy grazing is the compacted condition of the soil which often results. Light grazing has no marked injurious effect, yet it undoubtedly has an influence in prolonging the life of the association.

\section{ILLUSTRATIVE EXAMPLES}

In order to present a more complete picture of the development of the red cedar-gray birch association the following examples are given:

Table $\mathrm{I}^{1}$ illustrates the nature of the growth coming in on an old field which has been abandoned for about eight years. In addition to the red cedar, there is a scattered growth of Berberis vulgaris, Rubus cuneifolius, Myrica carolinensis, and Vaccinium corymbosum. The herbaceous growth consists principally of grass, Verbascum thapsus, and Hieracium spp. Conditions on this area are shown in Fig. 2. Successional development is only slightly farther along here than on the area shown in Fig. I. This area illustrates the fact that the early tree growth on pastured old fields is usually a scattered stand of red cedar.

Table II illustrates the composition and structure of a typical red cedargray birch association which originated on an old field. The dominant trees are thirty-five years old. This stand occurs on gravelly soil, site quality II. There is a dense shrubby growth of Rhus copallina, Myrica carolinensis, Juniperus communis, Rosa sp., and Rubus villosus. A dense growth of grass and Solidago spp. covers most of the area. The Rhus copallina and Juniperus communis are rapidly dying out as forest conditions become established. The early appearance of such species as sugar maple and scarlet oak indicates that successional development toward the hardwood stage will be rapid on this site. The character of the stand is shown in Fig. 3 .

Table III illustrates the composition and structure of a red cedar-gray birch stand growing on an old pasture (Fig. 5). This stand is somewhat more advanced than the one illustrated in Table II. The dominant trees are fifty years old and thirty feet high. The soil is a sandy loam, site quality II. The association is very open, with a ground cover of Andropogon scoparius, Rumex acetosella, and Solidago spp. Scattered individuals or groups of Celastrus scandens, Myrica carolinensis, and Viburnum acerifolium also occur. The Juniperus communis is dying out, due to lack of ability to endure suppression. The red cedar also shows signs of deterioration. With the appearance of such species as black birch, white ash, red maple, white oak,

1 Tables are found on pages 45 to 67. 


\section{RED CEDAR-GRAY BIRCH ASSOCIATION}

and pignut hickory, the red cedar will soon be crowded out. The successional trend toward the hardwood stage is clear.

Table IV illustrates conditions in a stand somewhat farther advanced than the one illustrated in Table III. The dominant trees are sixty years old and forty feet high. The stand occurs on a moderately deep sandy loam, site quality II, near the stand illustrated in Table III. It came in on an abandoned field which was bordered on three sides by agricultural land, the fourth side being adjacent to a hardwood stand. It is significant that the occurrence of heavy-seeded species, such as the oaks and hickories, is confined to the borders of this stand. The lighter-seeded species, such as the maples and ash, are about the only hardwoods found near the center of the area. This points to the fact that heavy-seeded species are slower to populate isolated old fields than light-seeded species. Diameter growth of the red cedar has dropped off greatly in the past twenty years, and in the past ten years many trees have died, apparently because of their inability to endure suppression. About thirty per cent of the red cedar trees are dead and about sixty per cent of the basal area of the living red cedar is represented by trees in the two lower crown classes. The presence of abundant hardwood reproduction in the two lower forest layers, together with the lack of red cedar and gray birch, indicates the temporary character of the two latter species. The ground cover is sparse, consisting of occasional individuals of Mitchella repens, Lycopodium complanatum, Vaccinium corymbosum and Viburnum acerifotium. The character of this stand is shown in Fig. 7 .

\section{THE HARDWOOD ASSOCIATION}

\section{General Characteristics}

$7 \mathrm{HE}$ hardwood association is mesophytic in character. Its mesophytism

1 is indicated by the presence of various tree species which are recognized as mesophytes and also by the abundant lesser vegetation. See Table $\mathrm{XX}$. Its appearance is that of a mesophytic deciduous hardwood forest, as shown in Fig. I I and Fig. I2.

\section{TAXONOMIC FEATURES}

In the hardwood association there is great variation in composition, due to the large number of tree species in the region. An "inferior hardwood" and a "better hardwood" phase may be recognized; but these two phases are 


\section{UPLAND FOREST SUCCESSIONS}

merely developmental stages within the larger association. Very often during the early development of a hardwood association the inferior hardwoods predominate; dogwood, hop hornbeam, blue beech, red maple, shad bush, choke cherry, sassafras, butternut, pignut hickory, bitternut hickory, and large-toothed aspen. In the early developmental stages of this association, red cedar and gray birch individuals are often present with the inferior hardwoods, representing relics from a preceding red cedar-gray birch association. As the hardwood association approaches maturity, the inferior hardwood species become subordinate and the better hardwoods attain dominance. Such species as the following are considered better hardwoods: red oak, scarlet oak, white oak, chestnut oak, black oak, white ash, shagbark hickory, mockernut hickory, black birch, paper birch, yellow birch, beech, yellow poplar, black cherry, white elm, sugar maple, and basswood. With the establishment of the better hardwoods, hemlock may begin to appear. This species presages the successional development of the association toward the hemlock-hardwood stage. The hardwood species usually found in a typical hardwood stand are listed in Table XX. Over small areas pure stands of certain hardwood species may occur, but as a rule the forest is a mixture. With the loss of chestnut, due to chestnut blight disease (Endothia parasitica [Murr.] Ander. and Ander.), the oaks have gained greatly in dominance as compared with the other hardwood species. In fact, at the present time the oaks as a group make up a predominant part of the southern New England hardwood association. There is a scattered undergrowth of shrubs in this association as is indicated in Table XX. The density of the undergrowth, and also the composition, depends largely on the past treatment of the area and to a less extent, on the character of the soil. The herbaceous vegetation is rich, both in number of species and of individuals. The frequency of occurrence of the herbaceous species is indicated in Table XX.

\section{Distribution}

The hardwood association is found growing on all sites. The physical condition of the soil supporting hardwood growth is better than that of soil supporting the earlier red cedar-gray birch stage. Associated with successional development, the soil has come to have better tilth, a higher content of organic matter, and a more active soil flora and fauna. In hardwood soils the average thickness of the " $F$ " (duff) layer is $1 / 4$ to $1 / 2$ inch and of the " $\mathrm{H}$ " (humus) layer is $1 / 2$ to $\mathrm{I} / 2$ inches. The influence of the 


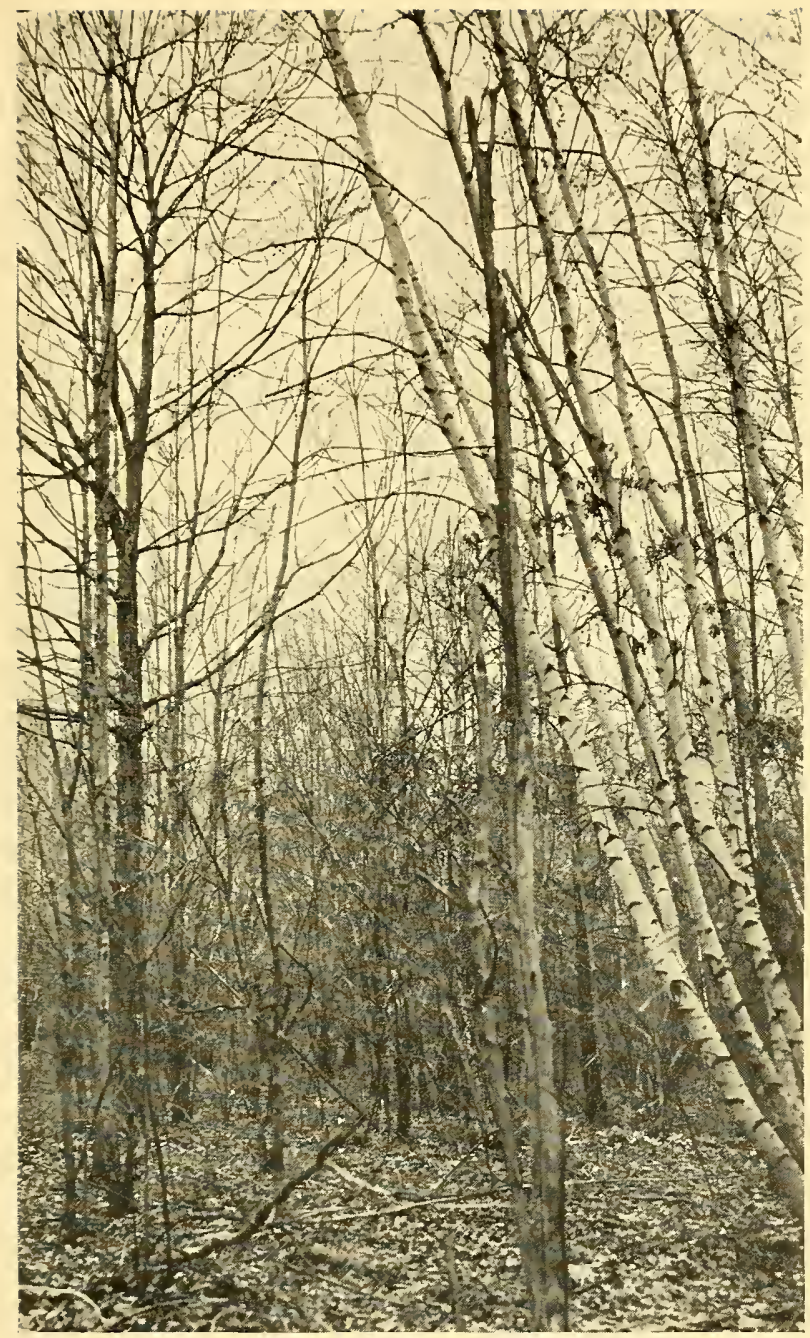

Fig. 9. A hardwood stand that initiated the forest succession on an old field which had been cultivated prior to its abandonment. 


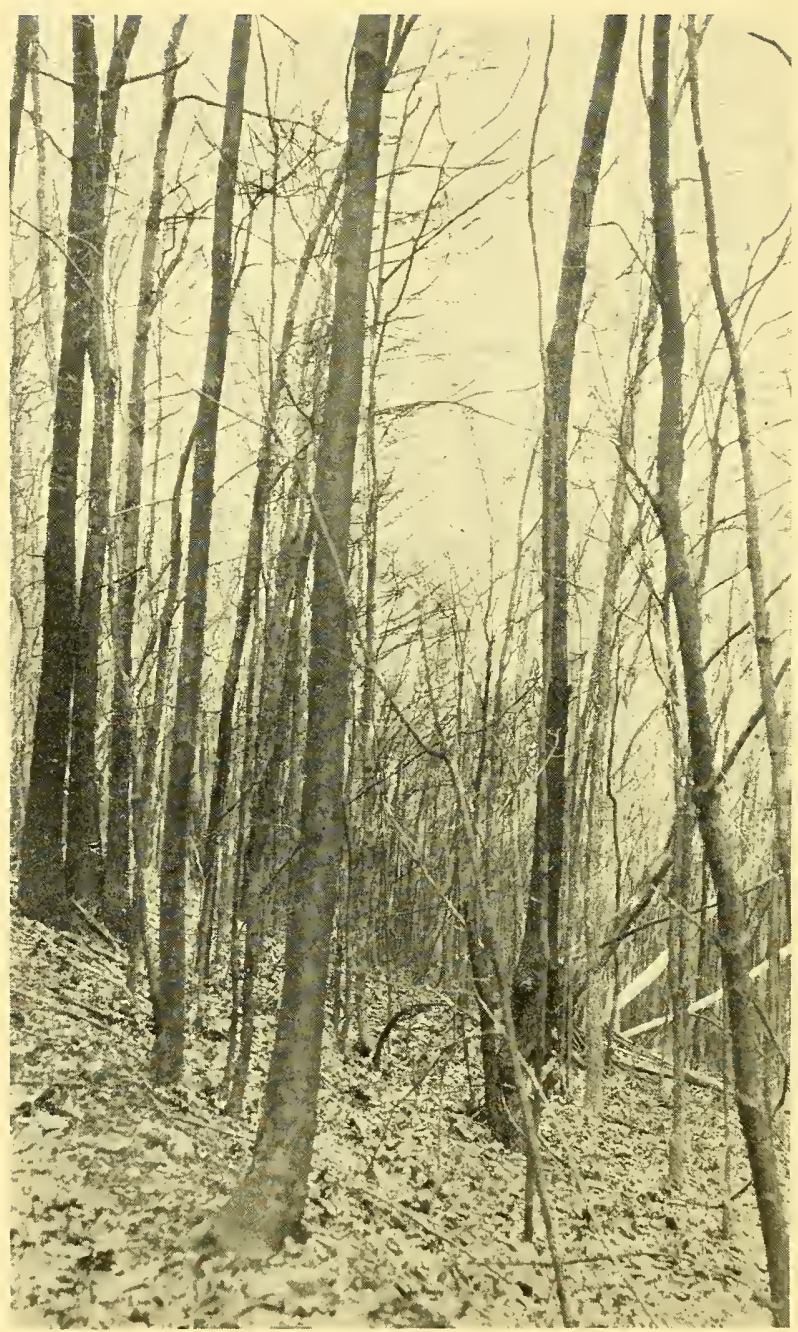

Fig. I o. An even aged stand of hardwoods that originated after clear cutting a hardwood stand in which chestnut predominated. 


\section{HARDWOOD ASSOCIATION}

stand in shading the soil is an important one. Shade lowers the soil temperature during the hottest part of the day and lowers evaporation from the surface soil. Shade also lessens transpiration from the young plants.

\section{SuCCESSional Relations}

The hardwood association normally follows the red cedar-gray birch stage. Scattered hardwoods become established in a red cedar-gray birch stand and gradually crowd out these pioneer species. As soon as red cedar is overtopped by hardwoods it rapidly loses vigor and dies. No instances were found where mature red cedar trees were able to stand suppression for more than a few years. In the seedling stage red cedar seems to be somewhat more tolerant of shade than in later life. Many places were seen where the only live mature red cedar trees in the stand were those which still maintained their crowns in full or nearly full sunlight. On the other hand, the shade of red cedar and gray birch is so slight that it has little if any detrimental influence on the growth of the young hardwoods; in fact it may be beneficial to them during juvenile growth, since it lowers soil temperature and evaporation.

The normal destiny of the hardwood association is succession toward the hemlock-hardwood stage. The rate of change depends on the character of the soil and the proximity of seed-bearing hemlock trees. Where the soil conditions are good, as on the better sites, succession moves more rapidly than where they are unfavorable, as on poor sites. Much depends on the presence of seed-bearing hemlock trees. With hemlock wholly excluded from large areas at the present time, this factor is often a limiting one in determining the rate of succession in the hardwood association.

\section{ANTHRopeic INFLUENCES}

Directly or indirectly the influence of man is responsible for the present widespread distribution of hardwood stands in southern New England. Since nearly all hardwoods are prolific sprouters, especially when young, they have been favored by the practice of clear cutting on short rotations, in contrast to the conifers. Furthermore, the uarrage wrought by frequently recurring surface fires has not been so severe in its effect on succession in the hardwood association as in other associations, particularly the hemlock-hardwood association. This is explained by the lesser severity of fires in the hardwood stands, due to somewhat lower inflammability of the débris, and to the greater capacity of the hardwoods for recovery. Unless 


\section{UPLAND FOREST SUCCESSIONS}

fires are very severe they do not induce much of a change in forest composition. They do, however, impoverish the soil and scar the trees. These fire scars later serve as points of entry for various insects and fungi. Heavy grazing may result in retrogression, which is manifest in the dense shrubby growth that often follows. This shrubby growth in turn offers severe competition to hardwood seedlings and may prevent their establishment for many years. Red cedar may also come in as a result of grazing. This species, like other conifers, is favored by the selective browsing of stock.

Regulated grazing may be used as an instrument in bringing about more rapid succession to the hemlock-hardwood stage. By removing herbaceous growth and trampling the forest litter, stock may bring about more favorable seed bed conditions for the establishment of hemlock. The stock browse the young hardwood growth but do not touch the hemlock. Thus, hemlock is freed from competition of hardwood reproduction. Pure hemlock stands may originate in this way (Fig. 15), as pointed out by Merrill and Hawley (1924).

\section{ILLUSTRATIVE Examples}

The following examples will illustrate successional development:

Table $\mathrm{V}$ illustrates the successional development from the red cedargray birch stage toward the hardwood stage. It illustrates conditions in a stand somewhat more advanced than the one depicted in Table IV. The dominant hardwoods are thirty-five years old and thirty-five feet in height. This association occurs on site quality $\mathrm{V}$. The stand is rather open with a ground cover of Andropogon scoparius, Carex spp., Aster sp., and Solidago $s p p$. The red cedar is rapidly dying out. The inability of mature red cedar to endure shading is shown by the fact that the only trees of this species over fifteen feet in height are dominant or codominant trees. The large amount of hemlock reproduction which has become established illustrates well the ability of this species to come in, even on the driest of sites. The early appearance of hemlock is unusual on so poor a site and very significant from the standpoint of succession. The average age of the hemlock is ten years. All of it has come in sin is the area has been protected from fire. The hardwood reproduction is of poor quality and chiefly of sprout origin.

Table VI illustrates the transition from the red cedar-gray birch stage to the hardwood stage, somewhat farther advanced than in the stand illustrated in Table V. The dominant hardwoods are forty years old and forty feet in height, and the dominant red cedar is sixty years old. This 


\section{HARDWOOD ASSOCIATION}

stand occurs on an old field, the soil of which is a sandy loam, site quality III. There is practically no herbaceous growth. The red cedar is rapidly dying out, about 85 per cent of the trees being dead, and the gray birch and Jumiperus communis are also disappearing. It is clear that the hardwoods are gaining dominance. Fig. 6 shows the character of this stand.

Table VII illustrates the composition and structure of a stand which is in transition from the red cedar-gray birch stage to the hardwood stage. This stage is somewhat more advanced than that illustrated in Table VI. The dominant hardwoods are forty-five years old and sixty feet in height; the red cedar is about fifty years old. The stand occurs on site quality II. Indications are that the red cedar came in on an old field which had been used as a pasture. The tract is surrounded by open fields on three sides. The stand is not dense, yet the only ground cover is a sparse growth of Mitchella repens and Veronica officinalis. Occasional individuals of Vaccinium corymbosum and Myrica carolinensis also occur. The red cedar is rapidly dying out, as shown by the fact that 50 per cent of the trees are dead. In general, the hardwoods on this area are of the light-seeded type. This is explained by the somewhat isolated character of the area, which has prevented most of the heavy-seeded species from reaching it as yet. The few oaks and hickories which do occur are found near the borders of the stand. On this particular area there has been a more or less complete telescoping of the red cedar-gray birch association and the hardwood association, the hardwoods having started soon after the red cedar became established. Fig. 8 shows the character of this stand.

Table VIII illustrates the character of a hardwood stand that started on a field which had been cultivated a short time prior to abandonment. The trees are forty-five years old and forty-five feet in height. The stand occurs on a fine sandy loam, site quality IV. There is a sparse ground cover consisting of Lycopodium complanatum, Chimaphila maculata, Epipactis pubescens, and Carex sp. This stand illustrates the fact that hardwoods may sometimes initiate the forest succession on abandoned fields which have been cultivated a short time prior to abandonment. Fig. 9 shows the general character of this stand.

Table IX illustrates the character of a hardwood association which originated after a previously existing hardwood stand had been clear cut. The dominant trees are forty years old and forty-five feet in height. The soil is a sandy loam on a gentle east slope, site quality V. Ground cover is lacking. The former hardwood stand contained a large amount of chestnut, as evidenced by the old stumps and dead sprouts. In the present stand, 


\section{UPLAND FOREST SUCCESSIONS}

black oak is rapidly gaining in dominance, while black birch and dogwood are falling into a subordinate position. The openings caused by the loss of the chestnut are rapidly becoming occupied by black oak. The stand is fairly characteristic of young, even-aged hardwood stands which follow clear cutting of hardwood associations (Fig. Io).

Table $\mathrm{X}$ illustrates the composition and structure of a typical hardwood association on site quality $\mathrm{V}$. This stand is ninety-five years old and the dominant trees are sixty-five to seventy feet in height. The stand occurs near the one illustrated in Table IX and represents conditions in a mature association. Viburnum acerifolium is common and scattered individuals of Vaccinium vacillans occur. There is practically no herbaceous growth, only occasional individuals of Chimaphila maculata, Polystichum acrostichoides, and Chimaphila umbellata being found. The pignut hickory is beginning to die, together with the black oak. The absence of hemlock in a stand of this age may be explained by failure of hemlock seed to reach the area or by repeated surface fires which have killed the hemlock growth. Of the two possibilities, the former seems the most probable. If undisturbed, this association, which is essentially even aged, will be replaced by an uneven-aged hardwood stand in which the proportion of beech and sugar maple will be greater. With fire protection it will be replaced, in time, by the climatic climax of hemlock-hardwood. Fig. I I shows the nature of this stand. Fig. I 2 shows the summer aspect of another typical hardwood association.

Table XI illustrates the trend of succession from a hardwood association to a hemlock-hardwood association. The age of the dominant hardwoods is seventy-five years and the average height sixty feet. The stand occurs on a loam soil which contains much broken rock, site quality IV. Herbaceous growth is lacking. Scattered dead red cedar trees are still standing, indicating that a red cedar-gray birch stand preceded the hardwoods. The red cedar was overtopped by the hardwoods and died when about sixty years old. The presence of the dead red cedar indicates that there has been a rapid successional development on this area. The absence of reproduction of hardwoods, such as the oaks, and the presence of a large amount of hemlock in both of the lower forest layers indicate a successional development toward the hemlock-hardwood association (Fig. I 5). While there is a large amount of white ash reproduction in the stand, it is significant that none of the trees have reached a height of over six feet.

Table XII also illustrates the transition from a hardwood association to a hemlock-hardwood association. This stand is somewhat more advanced than the one illustrated in Table XI. The hardwoods are about I 20 years 


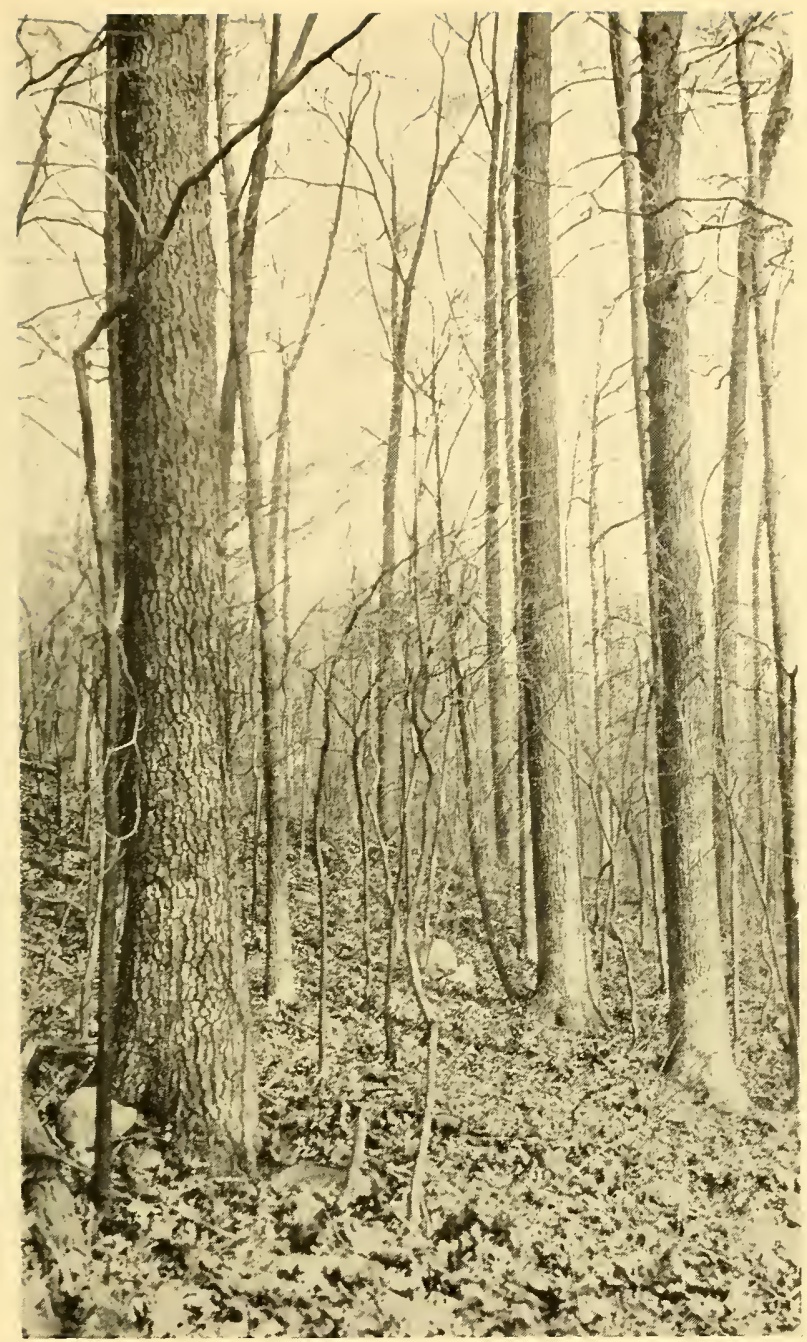

Fig. I I, A mature hardwood association in which black oak predominates. 


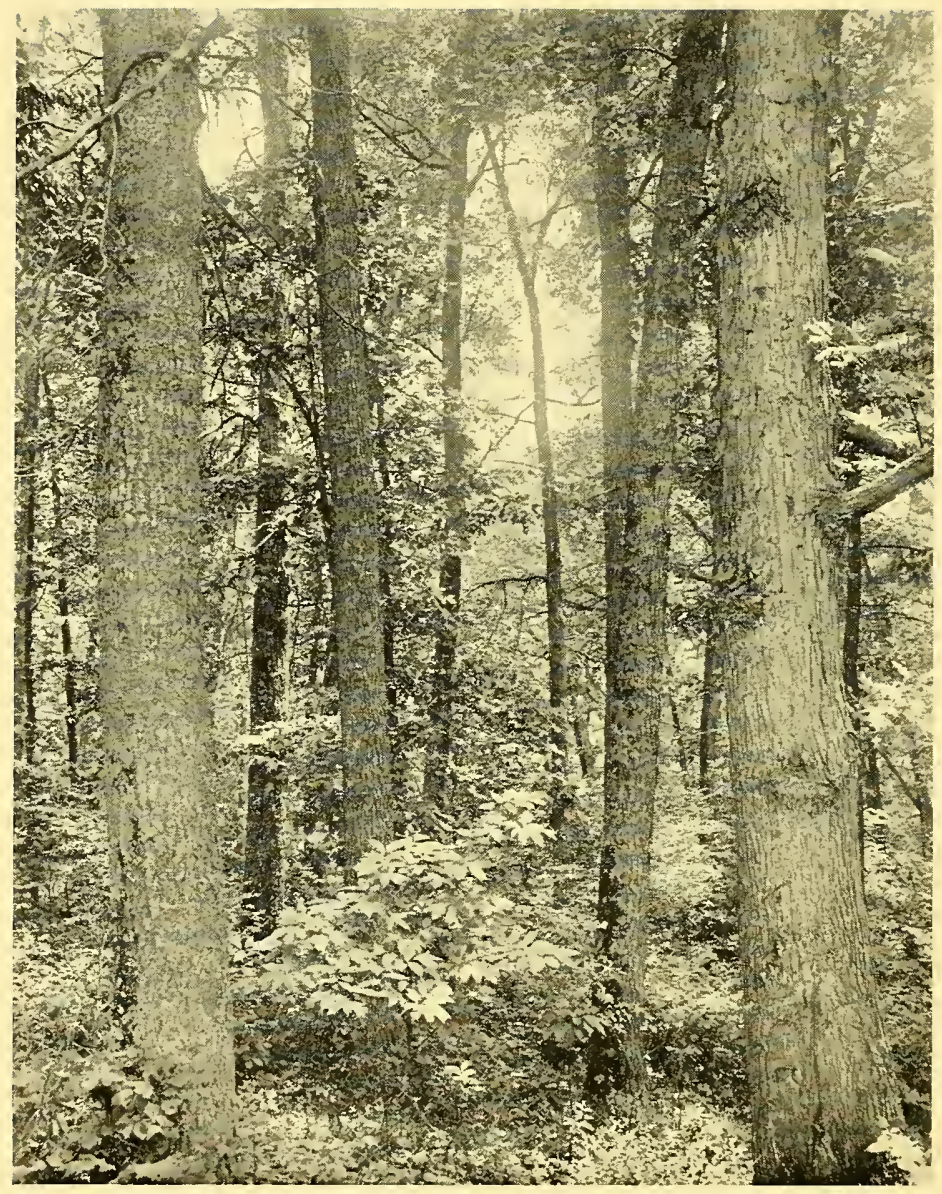

Photo by Dr. G, E. Nichols.

Fig. 12. A typical mature hardwood association in which oaks predominate. 
HARDWOOD ASSOCIATION

old and eighty-five feet in height. The stand occurs on a moderate south slope, site quality III. Relics of Juniperus communis indicate that the stand formerly had a very open character. As soil and moisture conditions became more favorable under the open hardwood stand, hemlock crept in until it now occupies an important place. While most of the hemlock is in the lower crown classes, it is all thrifty and will grow into a dominant position. The fact that hemlock is completely at home in this stand is attested by its distribution through all the three forest layers. The oaks are definitely lacking in both of the lowest layers and most of the other hardwoods are lacking in the second layer. Evidently, while some of the hardwoods are able to start, they are unable to survive long enough to attain a height of more than six feet.

\section{THE HEMLOCK-HARDWOOD ASSOCIATION}

\section{General Characteristics}

$7 \mathrm{HE}$ aspect of this association is that of a closed forest of evergreen 1 coniferous and deciduous broadleaf trees.

Moore, et al. (1924), in studies of the environmental conditions in pure hemlock and in hardwood stands, concluded that conditions were drier in hemlock stands than in those of mixed oak. The drier condition in hemlock stands may be partly due to greater air movement at the forest floor, as compared with mixed oak stands. The herbaceous and shrubby growth in the hardwood association tends to lessen air movement and to prevent excessive drying out. The conditions, with regard to air movement, in the hemlock-hardwood type are intermediate between those existing in pure hemlock stands and in hardwood stands.

An even more important factor in explaining the relatively drier condition under hemlock stands is the greater interception of precipitation by hemlock crowns than by hardwood crowns. Zon (1927) states that under average conditions a spruce forest will intercept about 39 per cent of the precipitation, a broadleaf forest, I 3 per cent. Assuming that hemlock intercepts about as much as spruce, the ground under hardwood stands receives a considerably larger amount of precipitation.

Cowles (I90I) states that all progressive succession is toward conditions of mesophytism and that succession away from mesophytism toward hydrophytism or xerophytism is retrogressive. On the other hand, Nichols (1923) points out that it is more nearly accurate to describe progressive 


\section{UPLAND FOREST SUCCESSIONS}

succession as succession toward a climax, for while there is a general tendency for vegetation to become increasingly mesophytic as a result of progressive successional changes, it is by no means an invariable rule. The views of the writer are in accordance with those of Nichols.

\section{TAXONOMIC FEATURES}

The composition of the hemlock-hardwood association is less varied than that of the preceding hardwood stage. The species occurring in this association, together with their frequency of occurrence, are listed in Table XX.

Hemlock usually makes up about 70 per cent of the stand (in per cent of total number of individuals) and the hardwoods make up the remaining 30 per cent. During the early development of this association, a relatively large number of hardwood species are represented. As the association grows older the composition becomes more specialized, with the result that some of the hardwoods are crowded out. In a well developed hemlock-hardwood association the species present have high frequency indices. The herbaceous and shrubby vegetation is sparse, as indicated in Table XX.

\section{Distribution}

This association grows on all upland sites in this region, from the poorest, on thin rocky soils, to the best, on deep rich soils.

The general physical condition of the soil in this association is good. The average thickness of the " $F$ " (duff) layer is from $3 / 4$ to $I$ inch and the " $\mathrm{H}$ " (humus) layer is $\mathrm{I}$ to $\mathrm{I} 3 / 4$ inches. The tendency for the various species to root at different levels in the soil makes for complete occupation at different depths. There is some indication that an unfavorable condition may sometimes arise in the organic soil layers under old pure hemlock stands. This unfavorable condition has to do principally with the slow rate of decomposition and the consequent excessive accumulation of organic débris.

\section{Ecological Relations in Hemlock Reproduction}

Shade, in its effect on soil moisture and temperature, appears to be of primary importance in the establishment of hemlock reproduction. Under natural conditions hemlock ordinarily reproduces and passes its early life in partial or full shade. In direct sunlight it reproduces poorly or not at all. The soil dries out and the weak roots of the seedlings are unable to obtain sufficient moisture; or else the surface soil becomes so heated that the 


\section{HEMLOCK-HARDWOOD ASSOCIATION}

tender plant tissues are killed. The effect of shade on hemlock reproduction is well illustrated in Fig. I 3 and Fig. I 4.

These chart quadrats were made in an old field which was largely covered with a grass sod, supporting in addition a sparse growth of Myrica carolinensis, Rhus glabra, Rhus copallina, and red cedar. Scattered about the field were a few isolated hardwood trees. Fig. I 3 and Fig. I 4 were made under such isolated trees. The field was bordered on two sides by a mature hemlock-hardwood association which supplied ample seed to the area. It is of importance to note that in every case the hemlock seedlings came in only where there was shade during the hottest part of the day, that is, on the north and east sides of the trees.

The effect of shade on hemlock reproduction is even more strikingly shown in another locality in this same field. Along the edge of the hemlockhardwood stand on the south side of the field are three large oak trees. These oaks have developed broad crowns which project out over the field and shade large semicircles. In the shaded semicircles is a very dense reproduction of hemlock, with occasional black birch, as shown in Fig. I6.

Another illustration of the effect of shade is afforded by an opening near the head of Lake Saltonstall where dense reproduction of hemlock is coming in on grass sod which receives partial to full shade most of the day. Close by, in full sunlight, there is practically no hemlock reproduction. Mature hemlock seed trees occur on both sides of the opening and scatter seeds on all parts of it. Two strips were run, each 500 feet long, and quadrats of nine square feet were established at fifty-foot intervals along the lines. One of these strips was in the shaded zone and the other was in the zone exposed to full sunlight. As shown in Fig. 17, conditions other than shade appeared to be identical. The reproduction on these two strips is recorded in Table XIII. The lack of hemlock on the strip exposed to full sunlight is ascribed to the effect of insolation in heating and drying out the surface layers of soil.

Studies of hemlock reproduction were also made in an area where group selection cuttings had been made in a mature hemlock-hardwood association seven years ago. A dense growth of black birch has come in near the center of the openings made by the cutting, where there was considerable direct sunlight. In the zone along the south edge of the openings, on the other hand, in places where partial to full shade was afforded during the hottest part of the day, abundant hemlock reproduction was found. Numerically, there is about as much black birch in the shaded zone as in the center of the opening, but there is a great difference in the size of the 


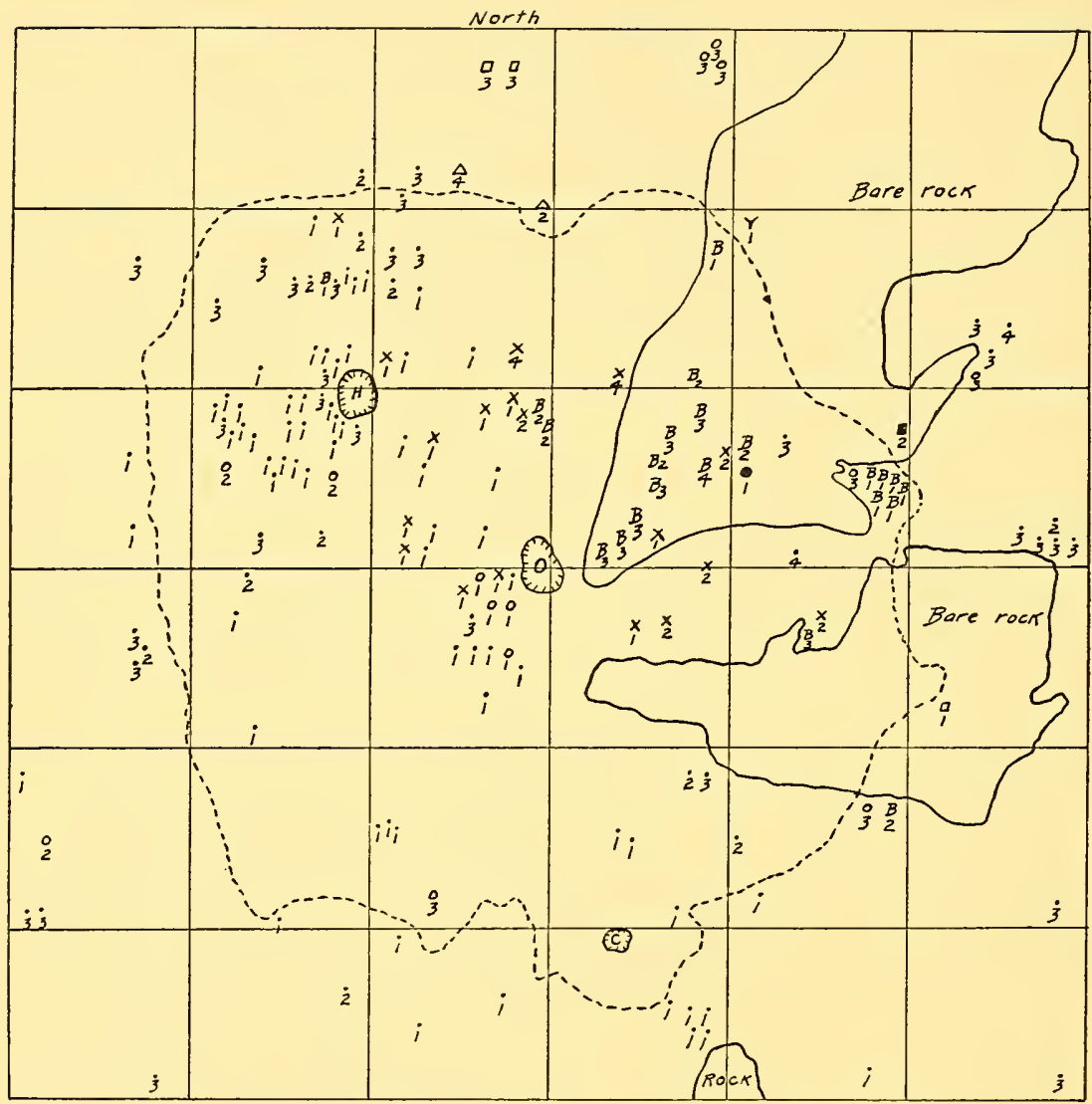

Fig. 13. The relation of shade to hemlock reproduction. Legend: • Red Cedar; $X$ hemlock; $\square$ choke cherry; O gray birch; B black birch; $O$ juniper; $Y$ red maple; $\Delta$ black oak; $C$ bare rock; (c) red cedar 8 inches D.B.H.; 0 black oak sprouts, 12 and 14 inches D.B.H.; (나 pignut hickory sprouts, 8 and 11 inches D.B.H.; vertical projection of tree crowns. The figures below the symbols refer to height: up to I foot; $2 \longrightarrow$ to 2 feet; $3-2$ to 6 feet ; $4-6$ to 15 feet. Scale-I square equals roo square feet. 


\section{HEMLOCK-HARDWOOD ASSOCIATION}

trees. In the area obtaining direct sunlight the black birch is nearly all over six feet in height, while in the shaded zone it is not over two feet. Lack of root competition is a factor which may explain to some extent the good growth of black birch in the openings. On the other hand, the relatively

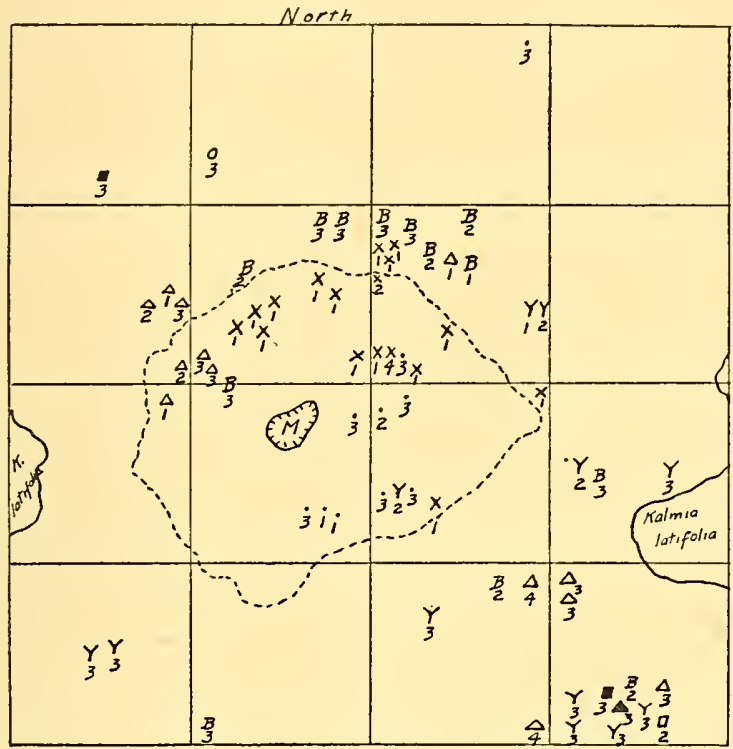

Fig. 14. The relation of shade to hemlock reproduction. Legend : $\bullet$ red cedar; $X$ hemlock; $Y$ red maple ; blue beech; $\square$.choke cherry; $\square$ pignut hickory; $\Delta$ black oak; B black birch ; $O$ gray birch ; (C) red maple sprouts, $2,4,6$, and 8 inches D.B.H.; tree crowns. The figures below the symbols refer to height: $1 \rightarrow$ up to I foot; $2-1$ to 2 feet; $3-2$ to 6 feet ; $4-6$ to 15 feet.

Scale-i square equals roo square feet.

better growth of hemlock near the edges of the openings than near the centers cannot be explained on this basis. Hemlock would very clearly seem to be a species which requires a shaded site for early growth, while black birch appears to do best when it receives full sunlight. Mowat (1927) states that the birches do not find the shady forest floor a suitable seed bed. 


\section{UPLAND FOREST SUCCESSIONS}

\section{Successional Relations}

The hemlock-hardwood association normally follows the hardwood stage. Hemlock individuals become established under the hardwoods and are able to live under suppression for long periods. Their persistence under suppression is remarkable. Equally important, from the standpoint of succession, is their ability to recover and grow rapidly when released, as is indicated by Marshall (1927). A third factor which contributes to the importance of hemlock in forest succession is its longevity. Frothingham (1915) reports ages of 500 to 600 years in some cases. Thus, hemlock is able to invade a hardwood stand and persist for many years under unfavorable conditions. During this period it is growing slowly and is gradually reaching up into the lower hardwood crowns. As individual hardwoods die of old age, injuries by insects, or any other cause, openings are created in the forest canopy. The hemlocks nearest such openings then rapidly push their way up and become a part of the principal stand. Hemlock by virtue of its longevity is more persistent than the competing hardwoods.

The climatic climax association. There seems to be little question that hemlock-hardwood is the climatic climax association on the upland soils of southern New England. Practically speaking, its normal destiny is perpetuation as the climax, since it represents the most advanced type of vegetation capable of development under the existing climatic conditions. The following considerations lead to this conclusion:

I. The present stands on areas which have been undisturbed for a long time are hemlock-hardwood. In southern New England most of the upland forest has been repeatedly subjected to such disturbances as cutting, fire, grazing, etc. A dense population, with markets for nearly all forest products, has been responsible for the widespread forest exploitation which has taken place. Occasional areas, inaccessible and protected from fire because of topography, have suffered relatively little disturbance. Some such areas exist to-day on steep rocky slopes and in deep rocky ravines. The ravines have been protected from fire to a large extent by the cool, damp environment and by their topographic isolation. In such places, where natural conditions have afforded a high degree of protection, the climatic climax forest has persisted. Fig. 26 and Fig. 27 illustrate such areas.

2. The last virgin forest area in Connecticut (Fig. I8) supported a stand in which hemlock was one of the dominant species. This stand occurred in the town of Colebrook, in the northwestern part of the state, and has been described by Nichols (1913). While the Colebrook forest rep- 


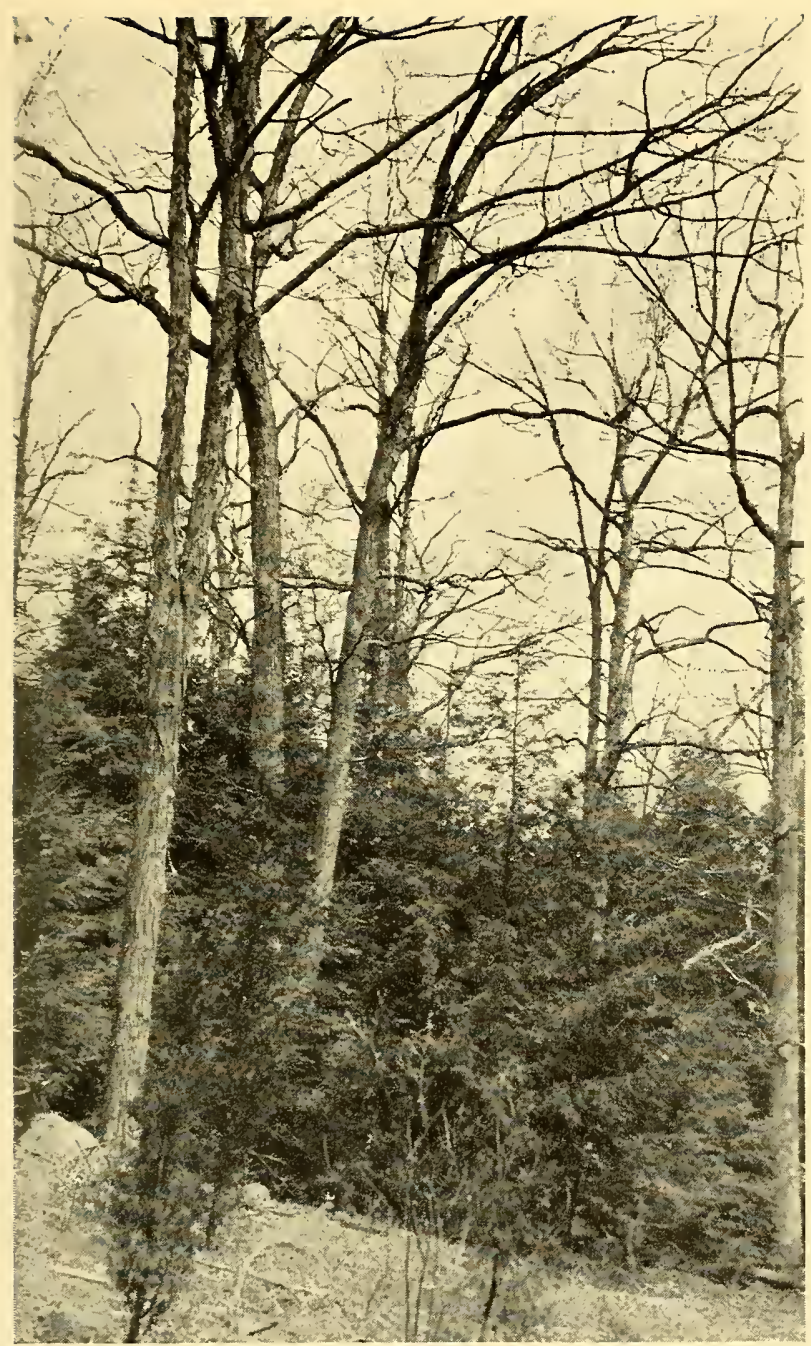

Fig. I 5. A mature hardwood stand with a dense under story of hemlock. Grazing was instrumental in causing the hemlock to become established. 


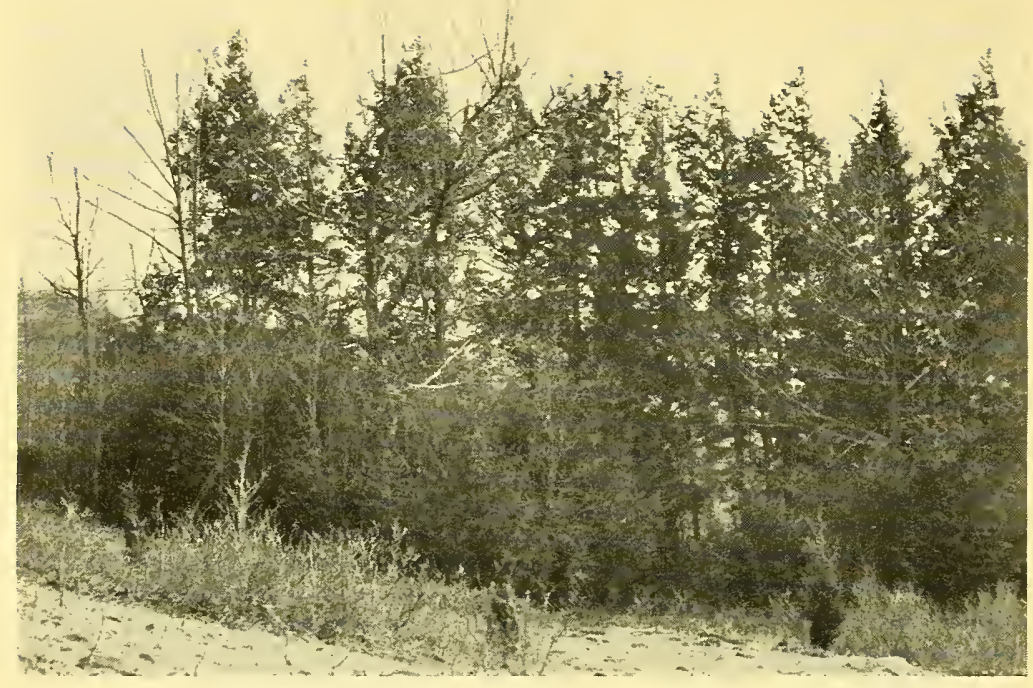

Fig. 16. Dense hemlock reproduction in an old field on areas shaded by large oak crowns.

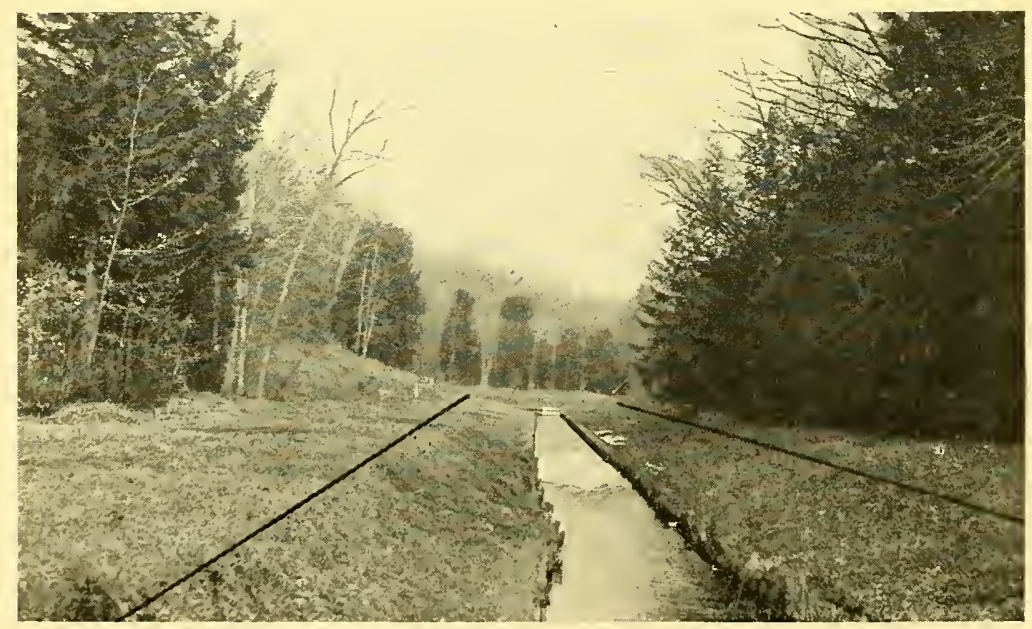

Fig. I 7 . The strip on the south (right) was partially shaded and showed abundant hemlock reproduction; the one on the north (left) was exposed to full sunlight and showed practically no hemlock reproduction. Saltonstall Tract, New Haven Water Company. 
resents conditions in a region somewhat farther north than the one under discussion, the similarities are greater than the differences. Further, the study made in the Colebrook forest is the only authoritative record we have of the virgin forests of Connecticut. Nichols found that the climatic climax forest which persisted over the greater part of northwestern Connecticut, as exemplified by the Colebrook area, was characterized by the predominance of hemlock and beech. On the whole these two species were about equally abundant and, taken together, comprised at least 55 per cent of the entire stand. The relative proportions of the two were found to vary, but almost without exception one or the other was dominant. The remainder of the forest was made up approximately as follows (in per cent of the total number of trees): sugar maple, 12; yellow birch, Io; red oak, 6; chestnut, 6; white ash and basswood, 7 ; black cherry, red maple, black birch, and white pine, 4.

Due to the chestnut blight disease (Endothia parasitica [Murr.] Ander. and Ander.), the chestnut as a mature tree has disappeared completely from the forests of southern New England. It is of interest also to note that beech of seedling origin is scarce in this region, practically all reproduction of this species being vegetative. Indications are that the reason for this condition lies in the fact that young beech trees apparently do not produce viable seed. With longer rotations the percentage of beech seedlings probably can be increased.

3. The successional trend in the upland forests of southern New England is toward the hemlock-hardwood stage. Many examples are available where hemlock has established itself under hardwoods and has gradually forced its way up to a dominant position. This process is taking place not only on the relatively moist north and east slopes, but also on the drier south and west slopes as well. While all succession tends toward the hemlock-hardwood stage, no tendency toward natural replacement of this association by some other type could be discovered.

4. From a purely theoretical standpoint, hemlock is admirably suited for its place as the dominant species in the climatic climax forest. In fact, no other native species is so well fitted. Hemlock has the ability to reproduce and develop in the densest shade. It shows remarkable persistence under suppression and may live for many years under conditions which would prove fatal to other species. Rapid growth is made as soon as the tree is released by the openings which occur from time to time in the forest canopy. Its great longevity, which enables it to outlive most of its competi- 


\section{UPLAND FOREST SUCCESSIONS}

tors, is another important characteristic. Furthermore, in natural stands the hemlock has few serious insect or fungous enemies.

Since a stand of hemlock-hardwood is the climatic climax on the uplands of southern New England, no progressive changes are to be expected. Retrogressive changes, however, such as are described on the following pages and illustrated in Tables XIV, XV, and XVI, are often more pronounced than in any other association. It is not uncommon to find cases where retrogression, due to clear cutting or fire, results in establishment of a stage even below the red cedar-gray birch association. This condition is explained by the fact that the climatic climax is in a delicate equilibrium with the edaphic and biotic factors of site; further, that the climatic climax forest is composed of a comparatively small number of specialized species. The specialized species of the climax forest usually find the change of conditions which follows severe disturbances much to their dislike.

\section{AnTHRopeic INFLUenCes}

The direct and indirect influences of man have resulted in widespread destruction of the climatic climax forest. The only areas now supporting it are those which have suffered a minimum of disturbance. There are several reasons why man's influence has led to such serious results. The inability of hemlock to reproduce by sprouting and its extreme sensitiveness to fire are important reasons for its decrease in the upland forests. The practice of clear cutting on short rotations has favored the hardwoods which are prolific sprouters in contrast to the conifers, which are not sprouters. Even if a few hemlock seedlings do become established after cutting, they are almost sure to be killed by surface fires. Another unfavorable factor is the sensitiveness of the young seedlings to exposure. The juvenile root system of hemlock is characteristically without a tap root, developing only laterals. Toumey (1926) states that the initial root system of hemlock is short and superficial, seldom reaching a greater depth than three to five inches the first season. Thus, on exposed sites hemlock may be unable to establish itself, since the downward penetration of its weak, slowly growing root system may be unable to keep ahead of the downward desiccation of the soil during critical periods. Toumey and Neethling (1924) have found that young hemlock is particularly sensitive to high surface temperatures. All these factors combine to make hemlock a species which has suffered very severely from the disturbances caused by man's activity. 


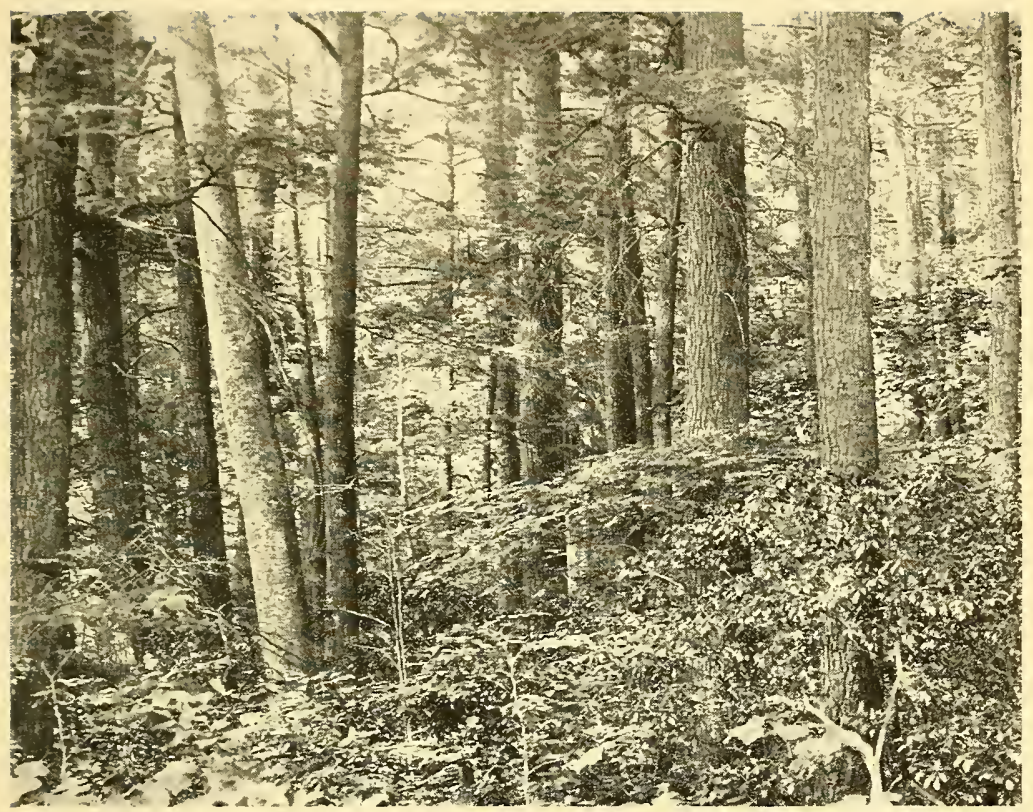

Photo by Dr. G. E. Nichols.

Fig. I 8 . A virgin forest of hemlock-hardwoods at Colebrook, Connecticut. 


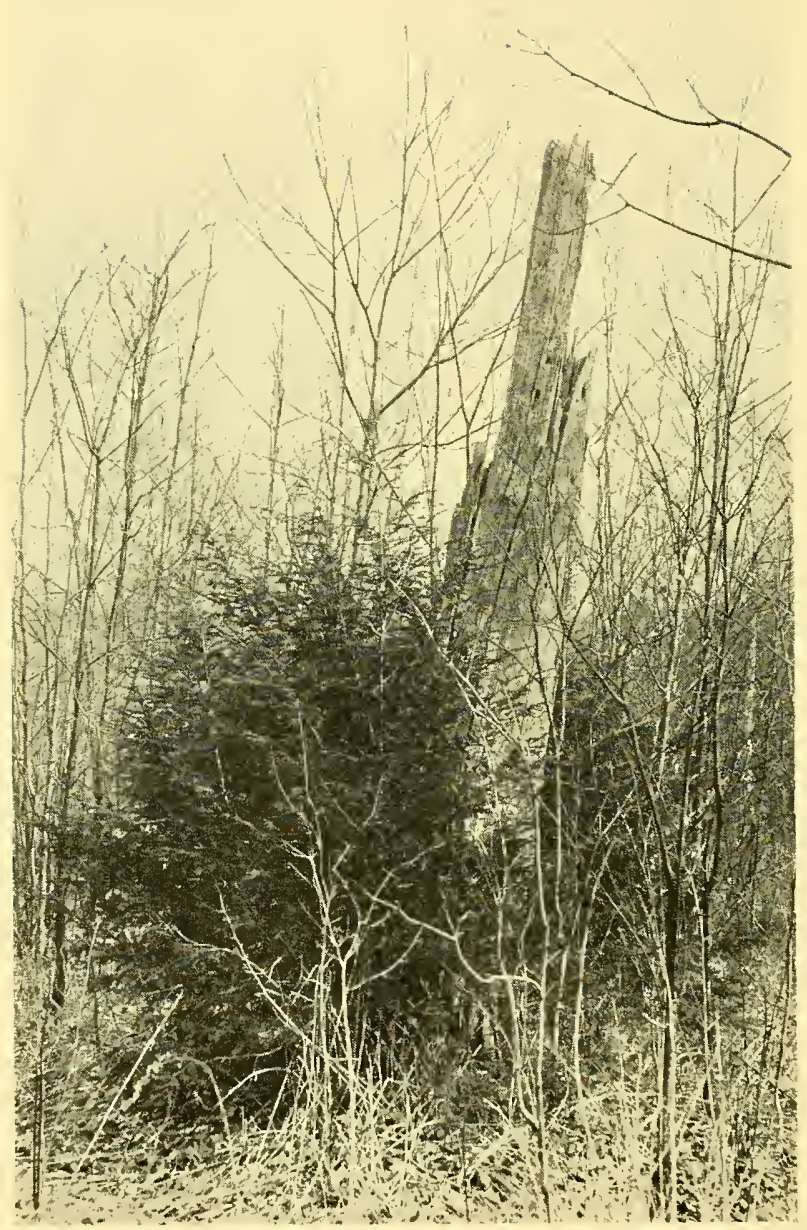

Fig. 19. A small group of hemlock reproduction which became established in a hemlock-hardwood association (now removed) when an opening was left in the forest canopy following the death of a tree. This group became established several years prior to the clear cutting of the stand. 


\section{HEMLOCK-HARDWOOD ASSOCIATION}

\section{ILLUSTRATIVE EXAMPLES}

Retrogressive succession. The following examples will illustrate the retrogressive changes which follow certain types of cutting in the climax forest:

Table XIV illustrates the composition of the stand which followed clear cutting in a virgin hemlock-hardwood forest. This area was clear cut sixteen years ago. The character of the original stand is shown in Fig. I 8 and described by Nichols (I9I3). The quality of the site is estimated to be II. For the most part the present stand is composed of inferior hardwoods, choke cherry and bird cherry being especially prominent. With few exceptions the only hemlock present is advance growth. The term "advance growth" is here applied to all reproduction which originated prior to the final removal of the old stand. Leffelman and Hawley (1925). Many instances were seen on this tract and on other areas similarly treated, where small groups of dense reproduction of hemlock had become established prior to the cutting. Conditions which favored such establishment were small openings in the forest canopy caused by the death of one or two trees. Fig. I9 affords an excellent illustration of this condition. As is shown later, this fact has considerable silvicultural significance.

The ground cover in this area is sparse, the principal species being Lycopodium clavatum, Mitchella repens, Solidago spp., and Rubus spp. This stand illustrates well the results of clear cutting the climax association before reproduction has been established. The character of the present stand is shown in Fig. 20.

Table XV, for another area, shows the character of the reproduction which came in when group selection cuttings were made in a hemlockhardwood association. The openings were made by removing comparatively large groups of trees nine years ago. The soil is a coarse sandy loam, site quality II. A study of the reproduction in these openings shows that, while hemlock seedlings do come in, they are so badly suppressed by black birch reproduction which comes in at the same time that their future development is doubtful. The average height of black birch in the center of the openings is about twelve feet and that of hemlock, only about one foot. A marked difference is noted around the edges of such openings where the ground is partially shaded. Here the black birch is dying out and its height growth is much less than in the center of the opening, while the hemlock reproduction is correspondingly better. The ability of hemlock to grow under hemlock-hardwood stands, in contrast to the inability of black birch, may be partly explained by the greater xerophytism of hemlock. 


\section{UPLAND FOREST SUCCESSIONS}

(The xerophytic nature of hemlock is indicated by its ability to grow in pure stands or groups on the driest of sites, while black birch occurs only as scattered individuals under such conditions.) In cuttings such as the one just described the retrogressive change is not great.

Table XVI, for a third area, illustrates the character of the growth eighteen years after clear cutting a hemlock-hardwood association on site quality III (Fig. 2I). Before removal the stand was essentially the same as that illustrated in Table XVII. Dense thickets of Rubus allegheniensis came in soon after cutting and are only now disappearing. Celastrus scandens is of common occurrence. A thin ground cover of Carex spp. is found over most of the area, with occasional individuals of Polystichum acrostichoides and Mitchella repens. The small amount of hemlock on the area is significant. In spite of the fact that mature hemlock trees occur within 300 feet, nearly all of the hemlock reproduction is advance growth. To a large extent the area is stocked with inferior species, such as gray birch, hop hornbeam, sumac, blue beech, and dogwood. The better hardwoods present are chiefly of sprout origin. The gray birch is rapidly dying out, about $5^{\circ}$ per cent of it being dead. Retrogression has been from the climatic climax association to the hardwood stage.

The climatic climax. The following examples will illustrate the character of the hemlock-hardwood association:

Table XVII illustrates the composition of a hemlock-hardwood stand in which the hardwoods still hold an important place. This stand represents a more advanced stage than that illustrated in Table XII. The association occurs on site quality III. Hemlock has come in under a hardwood stand and has gradually gained dominance. The reproduction is essentially hemlock, with hardwoods lacking. While much of the hemlock occupies a subordinate position at the present time, it is ready to assume a dominant position as soon as the hardwoods die. The hemlock is ninety years old and seventy-five feet high, while the hardwoods are about i 50 years old. There is no undergrowth and the only herbaceous cover consists of occasional individuals of Mitchella repens. Fig. 25 shows the general character of this stand.

Table XVIII illustrates the composition of a hemlock-hardwood association which has replaced a hardwood stand. The age of the dominant hemlock is ninety-five years and its height is seventy feet. The oldest hardwoods are upwards of $5^{\circ}$ years. The soil, site quality III, is a sandy loam containing much rock. Here the hemlock has gained almost complete dominance over the hardwoods. The composition is considered fairly typical of the 


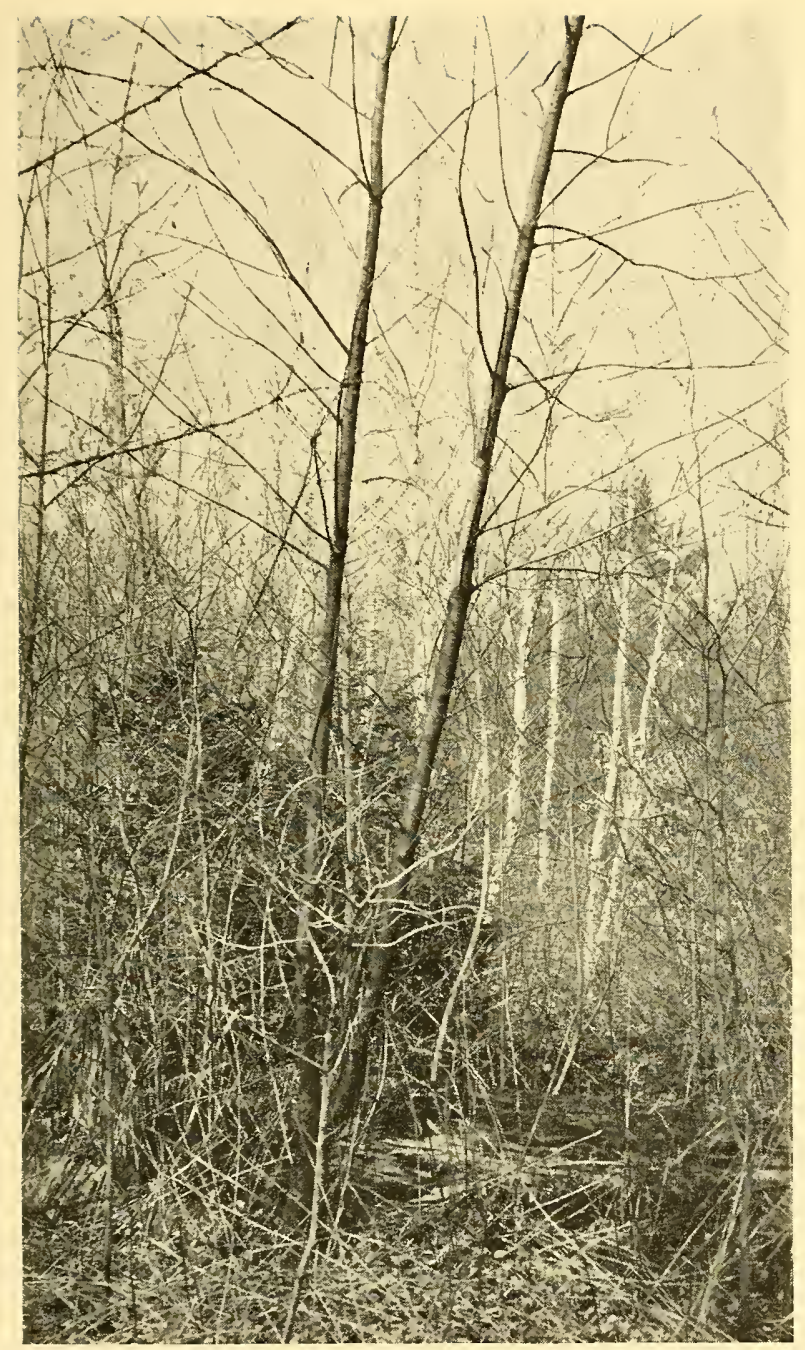

Fig. 20. A hardwood stand of inferior species which followed clear cutting in the climax forest shown in Plate XV. 


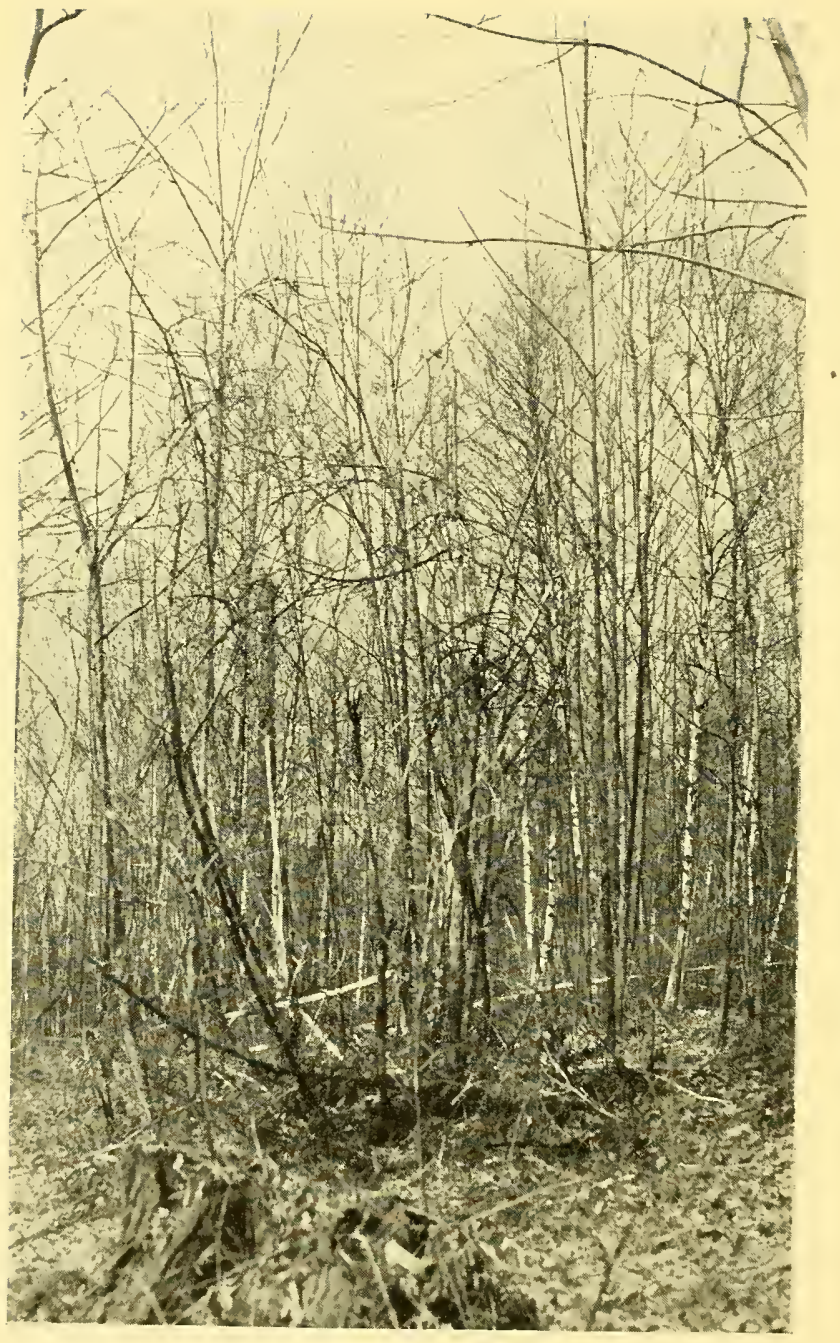

Fig. 21. A hardwood stand which originated after clear cutting a hemlock-hardwood association. New Haven Water Company. 


\section{HEMLOCK-HARDWOOD ASSOCIATION}

climatic climax forest. It is significant that while there is a large amount of chestnut oak reproduction, it is all in the lowest forest layer and none of it has reached a height of over six feet; in fact, none of it is over eight to twelve inches in height. It apparently persists for a time and then dies. Mowat (1927) concluded that advance reproduction of hardwoods is excluded from mixed stands with a large proportion of hemlock. Hemlock, on the other hand, is able to endure this same suppression and continues to grow, as indicated by the large number of trees in the six to fifteen-foot forest layer. No shrubby growth is present on the forest floor and the only herbaceous vegetation consists of scattered individuals of Mitchella repens and Polystichum acrostichoides. Fig. 26 illustrates conditions in a stand similar to the one described.

Table XIX illustrates the composition of a hemlock-hardwood association in which the hemlock has gained complete dominance (Fig. 27). This stand is approximately ${ }^{5} 5^{\circ}$ years old and the average height of the trees is ninety feet. It is growing on site quality II. The only herbaceous ground cover consists of scattered individuals of Mitchella repens. There is practically no shrubby growth. The conditions are scarcely typical of those in the climatic climax forest on the uplands of southern New England, the proportion of hemlock being higher than would be expected in the typical forest, while the number of hardwood species represented is rather low. However, this stand does represent a variation of the climatic climax which probably was of fairly common local occurrence in the original forest.

\section{SUMMARY OF STRUCTURAL AND SUCCESSIONAL RELATIONS}

\section{General Structure of the Upland Forest Associations}

$\mathrm{T}$ $1 \mathrm{HE}$ general structure of the three principal upland forest associations, 1 as already described, is illustrated by Fig. 22, which depicts in graphic form the degree of cover for each of the three vegetation layers here recognized, together, in a broad way, with the type of vegetation concerned. The characteristics and values here indicated may be taken to represent average conditions in well-developed associations. The essential features of these associations are summarized below, the three vegetation layers being referred to respectively as upper (vegetation more than fifteen feet high), middle (vegetation from six to fifteen feet high), and lower (vegetation less than six feet high). 


\section{UPLAND FOREST SUCCESSIONS}

The red cedar-gray birch association is very open, the degree of cover afforded by the upper vegetation layer ordinarily being less than 50 per cent but varying greatly. In pure gray birch stands it may reach as high as 100 per cent. The middle layer comprises a dense but more or less unevenly distributed growth of tall shrubs and small or immature trees; while the lower layer commonly presents an almost complete ground cover of young trees, shrubs, and herbs.

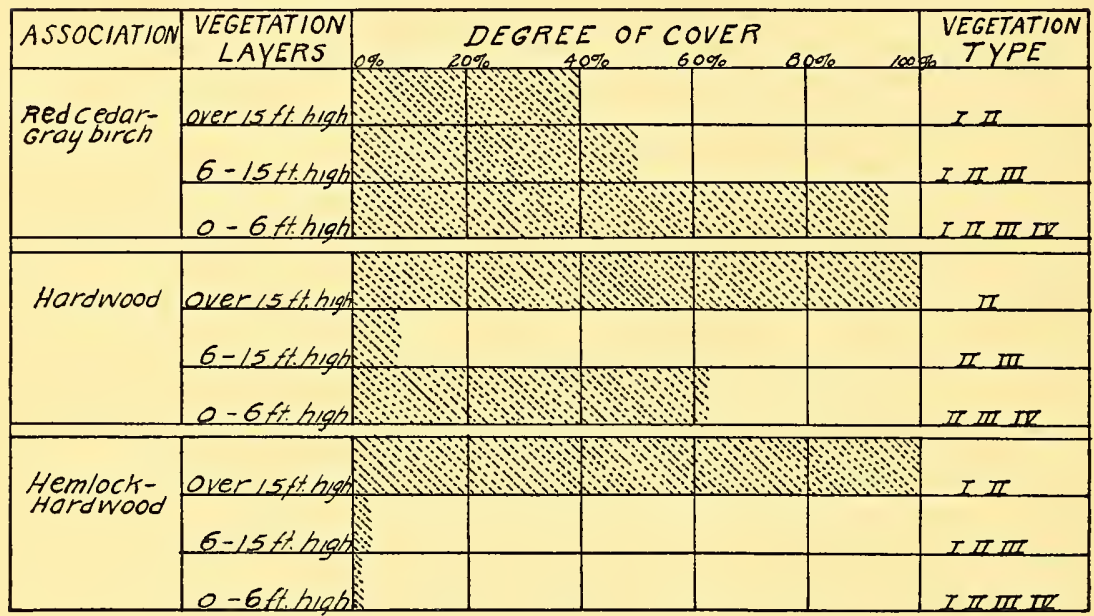

Fig. 25. Graphic characterization of principal forest associations. Under vegetation type: I-indicates coniferous trees, II-deciduous trees, III-shrubs, IV-low shrubs and herbs.

The hardwood association is closed, the trees in the upper vegetation layer forming a nearly continuous canopy. The middle layer here is much more thinly populated and correspondingly less prominent than in the preceding association. The lower layer also is less well developed. Representative examples of this association contain no coniferous trees.

In the hemlock-hardwood association the upper vegetation layer likewise forms a complete cover, of even greater density than in the hardwood association. The two lower layers, on the other hand, are very poorly developed. Hemlock is the only conifer present.

In general, the more primitive forest stands are characteristically open above with dense lower layers of vegetation. With successional development toward the climax, the crowns gradually close in, while the shrubby and 


\section{STRUCTURAL AND SUCCESSIONAL RELATIONS}

herbaceous growth thins out. Stands of the climax type tend to be closed above and open below, with a relatively scant development of the shrubby and herbaceous vegetation on the forest floor.

\section{Basal Area in Relation to Successional Development}

The total basal area per acre of the trees in any mature forest association (i.e., the total cross-sectional area of all the stems measured at breast height) is a feature whose ecological importance seems not to be generally recognized. Comparative study of the three associations under consideration has demonstrated that, for this series, there is close relation between their total basal areas and their degree of successional advance. In general, associations which represent early stages in the successional series are characterized by relatively low basal area values and those which represent later stages, by proportionately high basal area values, the climax association exhibiting the highest values of all. Average figures for the associations studied are approximately as follows:

\begin{tabular}{|lc|}
\hline & Basal area per acre \\
Association & Trees over 15 feet in height \\
Red cedar-gray birch & 40 to 75 square feet \\
Hardwood & 75 to I75 square feet \\
Hemlock-hardwood & 175 to 275 square feet \\
\hline
\end{tabular}

In this connection also, as might be expected, it was found that total basal area varies with site, being relatively low on the poorer sites and relatively high on the better ones.

\section{Successional Relations of Upland Forest Associations}

The general trends of upland forest succession in southern New England on various classes of land and under various conditions is outlined in Fig. 23 and Fig. 24. For the three land classes distinguished on the basis of past treatment (page II), under favorable conditions, the situation is essentially as follows:

In the case of old fields from which the former forest growth was wholly excluded by agriculture, the trend of succession depends, in the first place, on the quality of the site. On poor sites succession is slow, and usually passes first through a shrub stage, such species as Myrica carolinen- 


\section{UPLAND FOREST SUCCESSIONS}

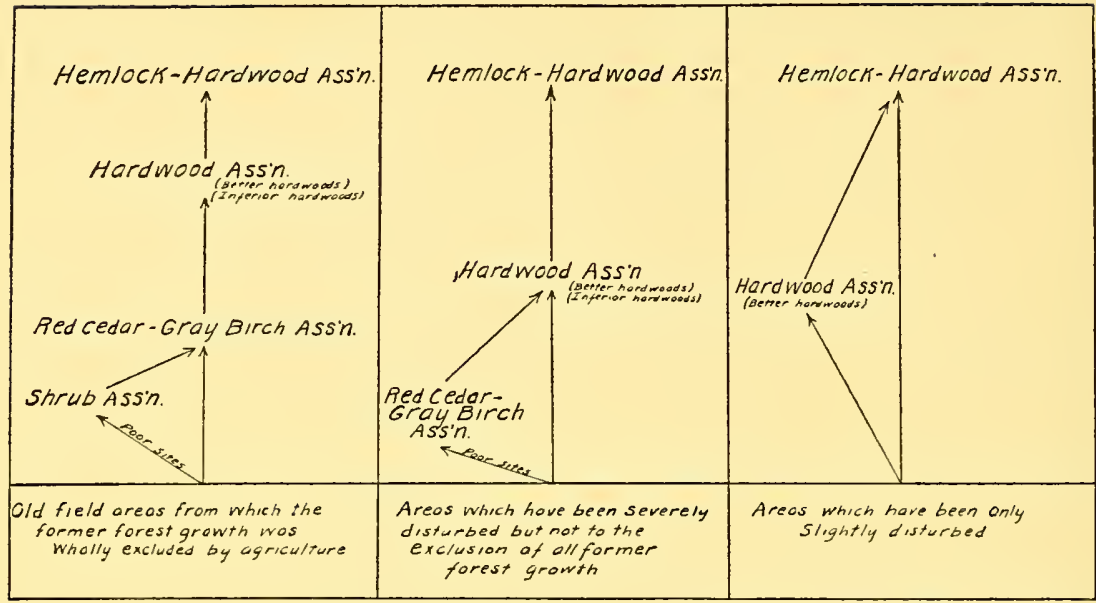

Fig. 23. The development of secondary forest successions on the uplands of southern New England.

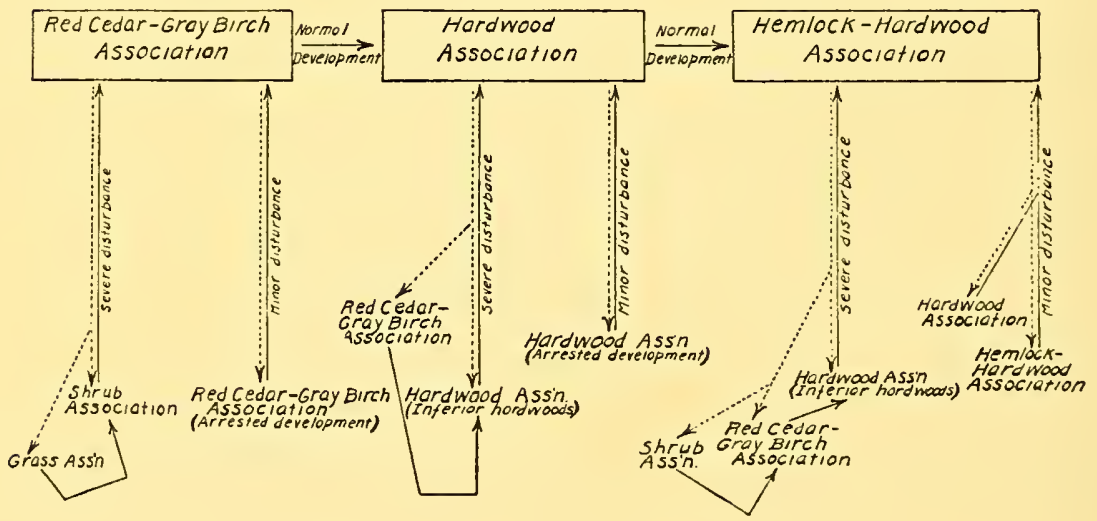

\section{Pragressive succession}

Retrogressive Succession...............

Fig. 24. The effect of disturbances on forest succession in the upland forests of southern New England. 
STRUCTURAL AND SUCCESSIONAL RELATIONS

sis, Myrica asplenifolia, Rhus glabra, and Rhus copallina being especially characteristic. From the shrub stage, development proceeds toward the red cedar-gray birch stage. On the better sites, the shrub stage is omitted, the red cedar-gray birch stage initiating the succession. Beyond this stage succession trends toward the hardwood association, with inferior hardwoods first and better hardwoods later. The hardwood association ultimately may give way to hemlock-hardwood forest, the climatic climax of the region. In general, succession on this class of land is slow.

On land which has been cut over, burned, grazed, or otherwise severely disturbed, but not to the exclusion of all former forest growth, hardwoods usually control the situation from the outset. As a rule inferior hardwoods predominate at first, later on giving way to hardwoods of the better type. On poor sites, however, the red cedar-gray birch stage may precede the hardwood stage. The climax stage here also is the hemlock-hardwood forest. In general, succession on this class of land is more rapid than on old field land.

On areas which have been only slightly disturbed the hemlock-hardwood stage may become reëstablished at once, or not infrequently there may be an intervening stage in which the better hardwoods predominate. Succession on this class of land is usually quite rapid, especially if fires are controlled.

The "normal" successional trends, as outlined above, may be variously interfered with by fire, grazing, and other disturbances. In particular, there may be retrogressive changes varying in kind and degree with the nature and severity of the disturbance. The general nature of these changes is suggested by Fig. 24, which scarcely requires further comment.

\section{SILVICULTURAL SIGNIFICANCE OF THE UPLAND} FOREST ASSOCIATIONS

\section{Red Cedar-Gray Birch Association}

$\mathrm{F}$ ROM a silvicultural point of view the greatest value of this association lies in its beneficial influence on soil conditions. With its development grass is killed out and woodland conditions are gradually established. It has high value as a nurse crop for the hardwoods which replace it.

Since the red cedar-gray birch stage ordinarily precedes the hardwood association, it is important to assure its unarrested development. Unnecessarily lengthened life of this stage, however, means that the establishment 


\section{UPLAND FOREST SUCCESSIONS}

of the more desirable hardwoods will be postponed. Perpetuation of the red cedar-gray birch association cannot be justified on silvicultural grounds, since the timber crops produced yield far less than may be obtained from the hardwood association or the hemlock-hardwood association.

\section{HaRdwood Association}

From the standpoint of present forest area the hardwood association is more important than any other. Timber production in this association is much higher than that of red cedar-gray birch, but is lower than that of hemlock-hardwood stands.

From the standpoint of silviculture this association is not as desirable as the hemlock-hardwood association. It does not occupy the site as completely as the latter and the quality of the timber produced is lower. In addition, it represents a successional stage short of the climax, one which will become increasingly more difficult and expensive to maintain.

\section{Hemlock-Hardwood Association}

Of the three upland forest associations this one is of highest silvicultural importance, since it is the climatic climax and capable of higher production than the hardwood association, as is indicated by Merrill and Hawley (I924).

Hemlock-hardwood stands bring about the most complete utilization of the site in timber production. There is excellent occupation of the growing space, both above and below ground. The tendency for layering, both in the aërial and subterranean portions of the trees, reduces competition and allows a greater number of trees to grow on a given area. Further, the association is self-perpetuating if undisturbed, and, being the highest type of forest the area is capable of supporting, it tends to maintain the quality of the site.

Tarbox (1924) states that hemlock growing in mixture with other trees has a beneficial influence upon its associates. Frothingham (I9I5) states that hemlock affords excellent protection to the site and points out its desirability from an æsthetic point of view. In natural stands it is remarkably free from serious insect or fungous enemies. Thus, the high value of the association from these several points of view argues for its maintenance under forest management. 


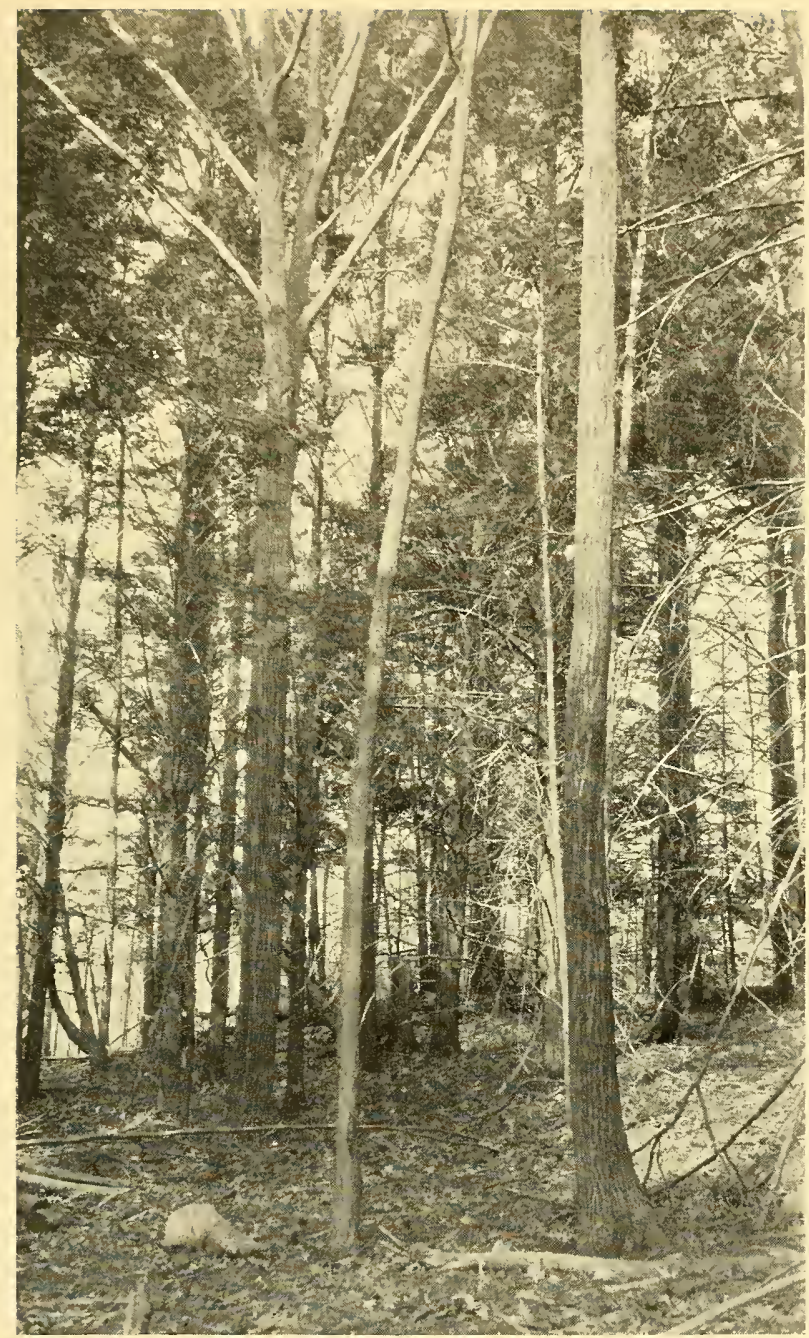

Fig. 25. A hemlock-hardwood stand in which the hardwoods still occupy an important place. New Haven Water Company. 


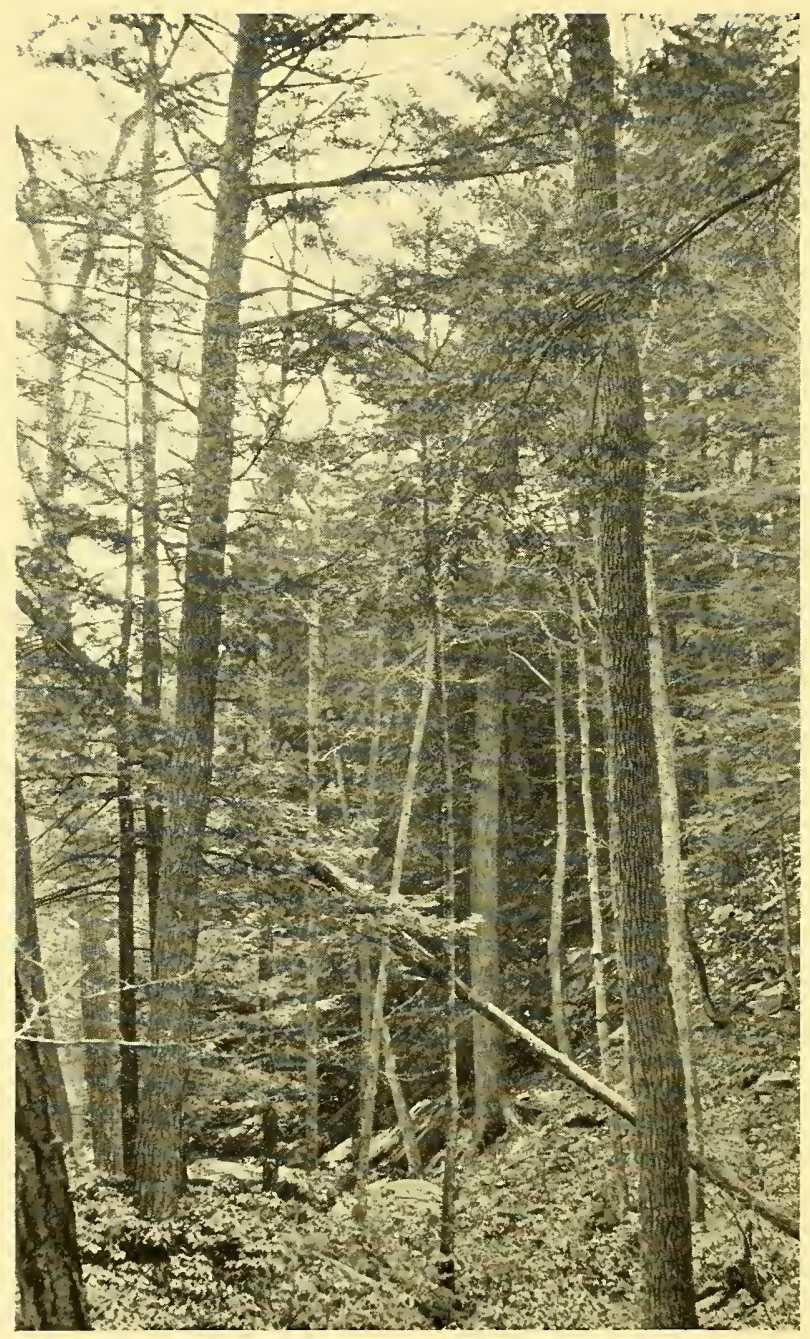

Fig. 26. A typical hemlock-hardwood stand which represents the climatic climax forest association on the uplands of southern New England. New Haven Water Company. 


\section{The "Ideal" Forest Association}

It would appear that the "ideal" forest association for southern New England, from the standpoint of silviculture, is one comprising a mixture of hemlock and hardwoods. Exactly what proportion of these two elements should be sought remains an open question; it probably varies considerably on different sites.

Of the various available hardwoods the most desirable are the oaksred oak, black oak, chestnut oak, white oak, and scarlet oak, together, on the better soils, with yellow poplar, white ash, sugar maple, basswood, shagbark hickory, and beech. A stand of this description closely approximates the climax association for the region.

Hemlock, the character species in such a mixture, as already pointed out, is a tree of relatively rapid growth and exercises a beneficial effect both upon the character of the soil which it inhabits and, when growing as an under story, upon the quality of the lumber produced by its associates. As the chief component naturally of the climax forest in this region it makes for the fullest occupation of the site.

Due to their rapid growth, the red and the black oak are probably the most desirable of the oaks, with chestnut oak, white oak, and scarlet oak but slightly less important. Reproduction in the red and the black oak is often difficult to secure and no satisfactory natural method has yet been found for greatly increasing the proportion of these species in the forest. Red, black, and white oak have their greatest value on the better sites (quality III or better), while chestnut oak is more adaptable to poor sites.

Pure hemlock stands are not considered as desirable as mixed stands, since they produce a comparatively low grade of lumber in contrast to the high grade material obtainable from mixed stands. In addition to presenting the disadvantages common to all pure stands, such a forest would be very difficult, or impossible, to maintain under forest management. In making cuttings retrogressive changes are brought about which inevitably result in an increase of hardwoods in the stand. In fact, it is impractical to keep the hardwoods out. 


\section{UPLAND FOREST SUCCESSIONS}

\section{SILVICULTURAL POLICY AND PRACTICE}

\section{Red Cedar-Gray Birch Association}

HE silvicultural policy to be followed in handling this association
should be to encourage its replacement by a stand of hardwoods. Cuttings in the red cedar-gray birch association should be made only to remove dead or dying material. On the better sites, red cedar is overtopped by hardwoods and dies when it is sixty to eighty years old, but it may persist for considerably longer on poorer sites. Since red cedar is used principally for fence posts, the practice of removing only dead trees would not prove impracticable. Gray birch is shorter lived and ordinarily dies when it is thirty to sixty years old. It should be removed before it dies, even if this involves clear cutting, since it decays very rapidly if left and becomes a total loss.

\section{HaRdwOOd Association}

Various silvicultural policies have been suggested for the management of the hardwood association. These policies may be classified as follows: (a) maintenance of the hardwood stands, (b) replacement naturally by the more advanced hemlock-hardwood association, or (c) conversion artificially to white or red pine.

At the present time much of the hardwood land in southern New England is entirely lacking in hemlock seed trees and will continue so for the next fifty years or more. On such lands, with natural reproduction of hemlock absent, the second policy mentioned above is obviously out of the question. Hence it becomes a question either of artificial conversion or maintenance of the hardwood stands.

The maintenance of the hardwood association, in case hemlock is present, should not be attempted, in view of the greater value of stands of the climax type. In addition, difficulties will be encountered in maintaining the hardwood type under such conditions. In many cases the hemlock reproduction under hardwoods is so dense that it prevents the establishment of hardwood reproduction. Under such conditions the hemlock must be removed if a hardwood stand is desired. Since hemlock is poor fuel wood, it cannot be removed profitably excepting at the end of the rotation, when it is large enough for dimension material. With better fire protection and the resulting spread of hemlock the maintenance of the hardwood type will become more and more of a problem. 


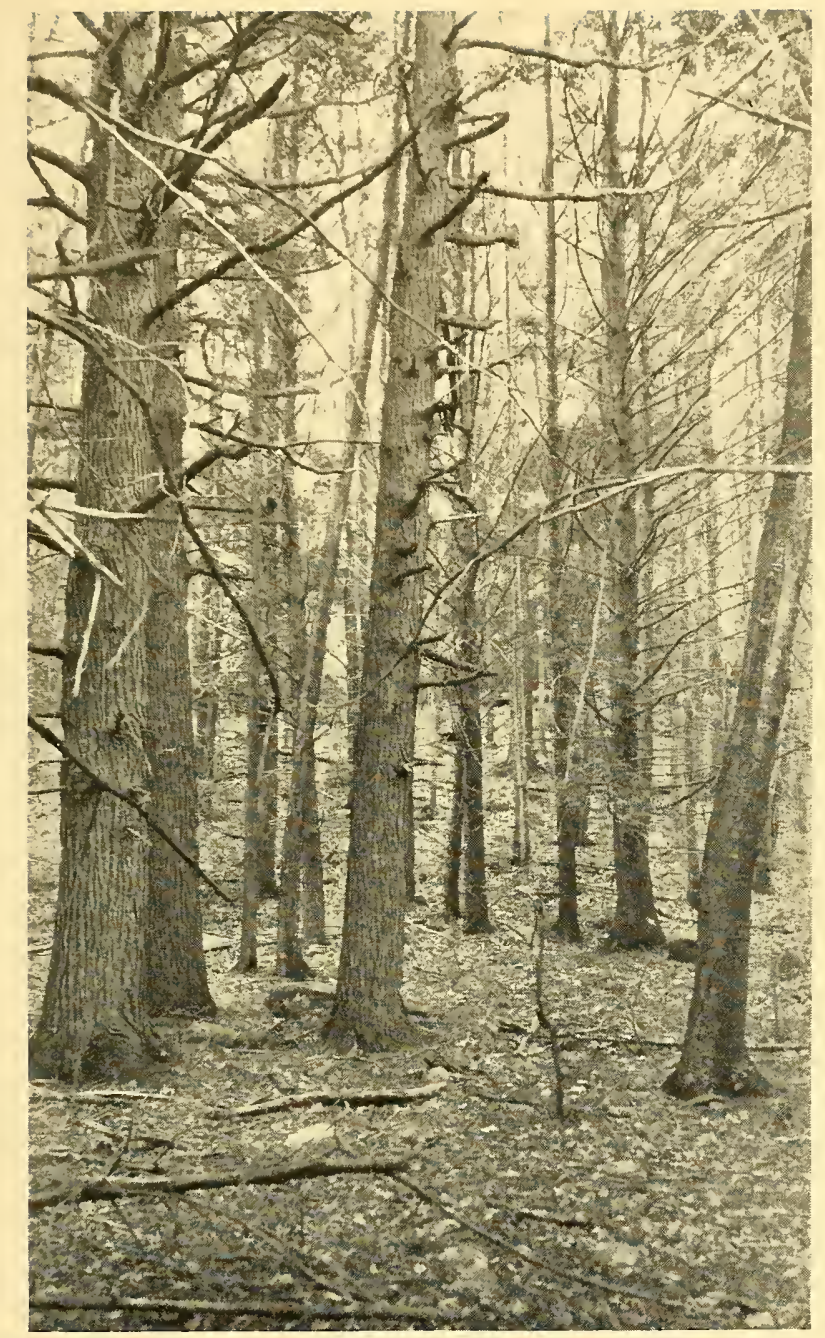

Fig. 27. A hemlock-hardwood association in which hemlock has gained complete dominance. 



\section{SILVICULTURAL POLICY AND PRACTICE}

The second alternative, replacement by a stand of hemlock-hardwood, has many advantages. First of all, it is the natural tendency. It offers nothing radical and is assured of success since it is the procedure which normally takes place in nature, provided hemlock seed trees are present or that there is advance hemlock growth. Conversion may be made naturally with very little expense. The advantages of the hemlock-hardwood stands have already been pointed out on page 30 .

The third alternative, conversion to pine, has been suggested by Frothingham (1912) and Durland (1922) because of the higher yields obtainable. Since there is no evidence of any natural tendency of pine to come in on hardwood land in this region, the conversion must be accomplished artificially. This means a large initial expense for planting that some owners will not feel justified in assuming. The costs which may be incurred in releasing the pine and establishing it in a dominant position over the hardwoods will also be considerable. While red pine has no serious insect or fungous pests, white pine has two serious ones, the white pine weevil (Pissodes strobi Peck) and the white pine blister rust (Cronartium ribicola Fischer de Waldheim). Control of these two enemies involves a still further investment. The disadvantages of pure stands in contrast to the advantages of mixed stands are well known and need not be mentioned here. Conversion of hardwood land to pine involves working against natural tendencies rather than with them. In view of all these considerations, conversion of hardwood stands to pine appears impracticable under present economic conditions.

Where the object of management is maintenance of the hardwood type, this can best be accomplished by means of shelter wood cuttings. Leffelman and Hawley (1925) have shown that abundant reproduction follows such cuttings. Grazing should not be permitted in hardwood stands which are to be maintained as such, since it favors hemlock reproduction and, if carried to excess, may result in establishment of various undesirable shrubs.

Where the object of management is conversion to hemlock-hardwoods the first essential is rigid fire protection. This is absolutely necessary. Light grazing of cattle or horses will favor hemlock at the expense of the hardwoods. Shelter wood cuttings or selection cuttings are well adapted to hardwood stands which are being converted, but clear cutting should be avoided. In hardwood stands there is little danger of competition from black birch since here the seed bed conditions are not favorable for this species. The exact silvicultural system to be used will depend largely on the local conditions. The main point to bear in mind is that, since the con- 


\section{UPLAND FOREST SUCCESSIONS}

version is in reality the natural trend of forest succession, it may be accomplished best by closely approximating natural conditions.

\section{Hemlock-HaRdwood Association}

The position of the hemlock-hardwood association as the climatic climax, together with other advantages which have been mentioned, indicates that the association should be maintained. In managing the hemlock-hardwood association it is necessary to secure hemlock reproduction before the final cutting is made. If the stands to be reproduced are even aged, a shelter wood cutting, or if uneven aged, a group selection cutting will result in starting abundant hemlock reproduction. As pointed out by Merrill and Hawley (1924), black birch reproduction may offer severe competition to young hemlock growth on areas where stands predominantly hemlock have been removed. Conditions of partial shade seem to be most favorable for the establishment of hemlock, while black birch thrives best in full sunlight. This difference in the requirements of the two species is so marked that it may serve as a basis for management practices designed to favor one or the other. By regulating the size of the openings in the forest canopy, hemlock may be favored at the expense of black birch. To accomplish this, reproduction cuttings must be very light. The openings should not be larger than twenty to thirty feet in diameter, with a maximum of about thirty-five feet. It is better to err on the side of too light a cutting, which fails to result in sufficient reproduction, than to make too heavy a cutting, which results in such abundant reproduction of light-seeded species, particularly black birch, that hemlock is either badly suppressed or temporarily excluded.

Clear cutting before reproduction is established is certain to result in retrogression and the establishment of a lower developmental stage. Even if hemlock reproduction is present, clear cutting is considered inadvisable because young hemlock is very susceptible to injury from exposure. The problem of securing sufficient numbers of desirable hardwoods in the mixture has not yet been solved. More knowledge of the requirements of the individual species is necessary before this problem can be handled satisfactorily. For the present it appears that application of the conservative silvicultural measures suggested for the maintenance of the hemlockhardwood association will result in stands with a fair proportion of desirable hardwoods.

Fires are particularly destructive in the hemlock-hardwood stands and 


\title{
LIST OF SPECIES
}

should be guarded against carefully. Grazing, if properly controlled, may be useful in restricting hardwood growth and encouraging hemlock on areas now containing too small a proportion of hemlock.

Since this association is the ultimate vegetational expression of the natural conditions of the region, success or failure in its management will depend largely on the degree of conformity to, or divergence from, the conditions of nature.

\section{LIST OF SPECIES WITH THEIR FREQUENCY OF OCCURRENCE}

\begin{abstract}
$\triangle$ COMPLETE list of the species referred to in this bulletin is given in 1 Table XX. The nomenclature here adopted for the tree species is that of Sargent's Mamual (1922); for the shrubs and herbs, that of Gray's Manual (1908).

The common names of the trees have been used throughout the text. In the case of the shrubs and herbs, due to lack of general usage of common names for some species, scientific names have been used throughout.

The relative frequency with which the various species occur in the three upland forest associations is indicated as follows: C, common; F, frequent; and S, seldom. Successional tendencies have been disregarded in this table; the estimate of frequency is based on mature individuals on representative areas.
\end{abstract}

\section{TABLE I}

THE COMPOSITION OF A YOUNG RED CEDAR-GRAY BIRCH STAND ORIGINATING ON A PASTURE

Based on .1o acre quadrat

\begin{tabular}{|lcc|}
\hline Species & $\begin{array}{c}\text { Total no. peracre } \\
\text { o-6 ft. high }\end{array}$ & $\begin{array}{c}\text { Frequency } \\
\text { index }\end{array}$ \\
\hline Red cedar & 580 & 4 \\
Gray birch & I0 & I \\
Apple & I0 & I \\
Juniperus communis & I 20 & 2 \\
\hline
\end{tabular}


UPLAND FOREST SUCCESSIONS

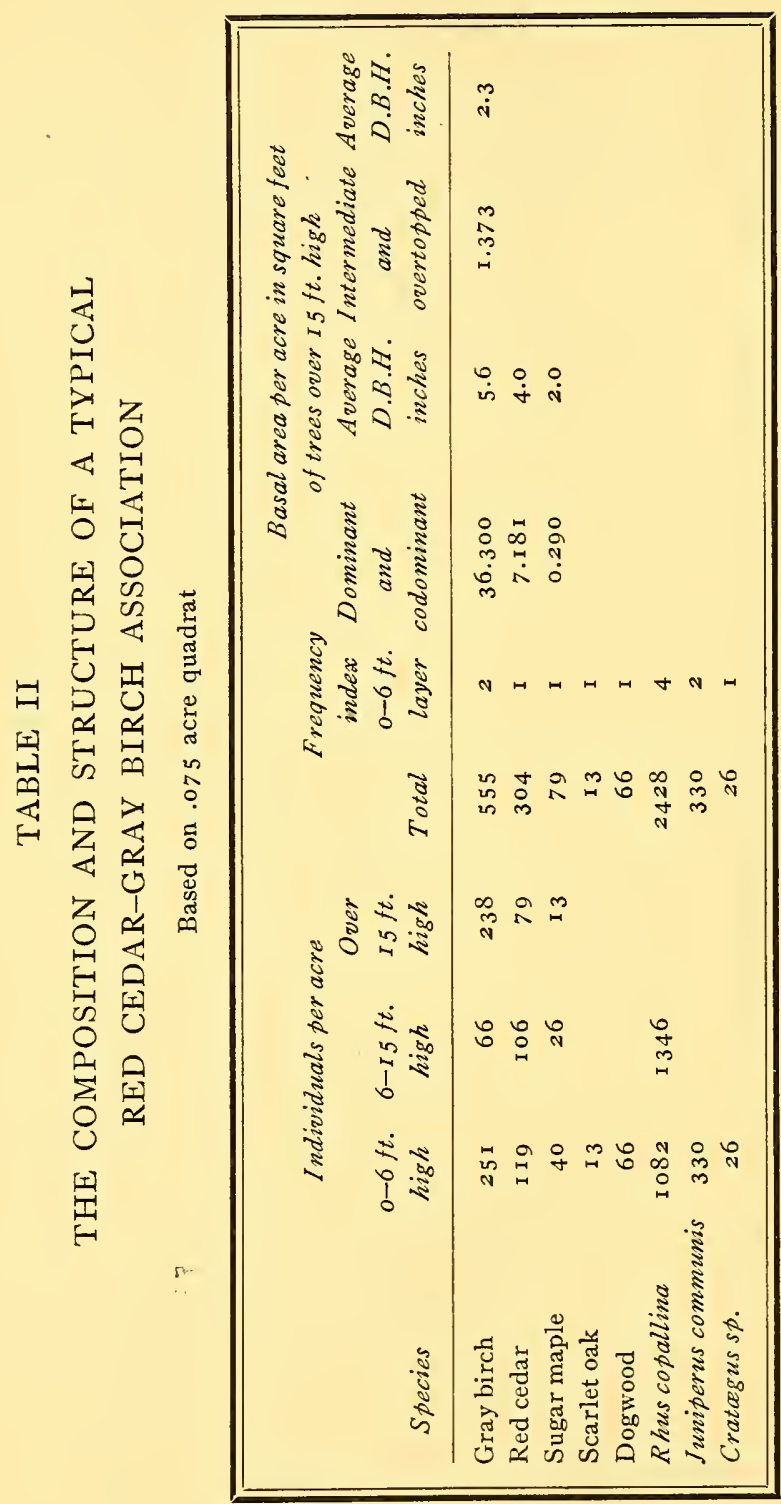




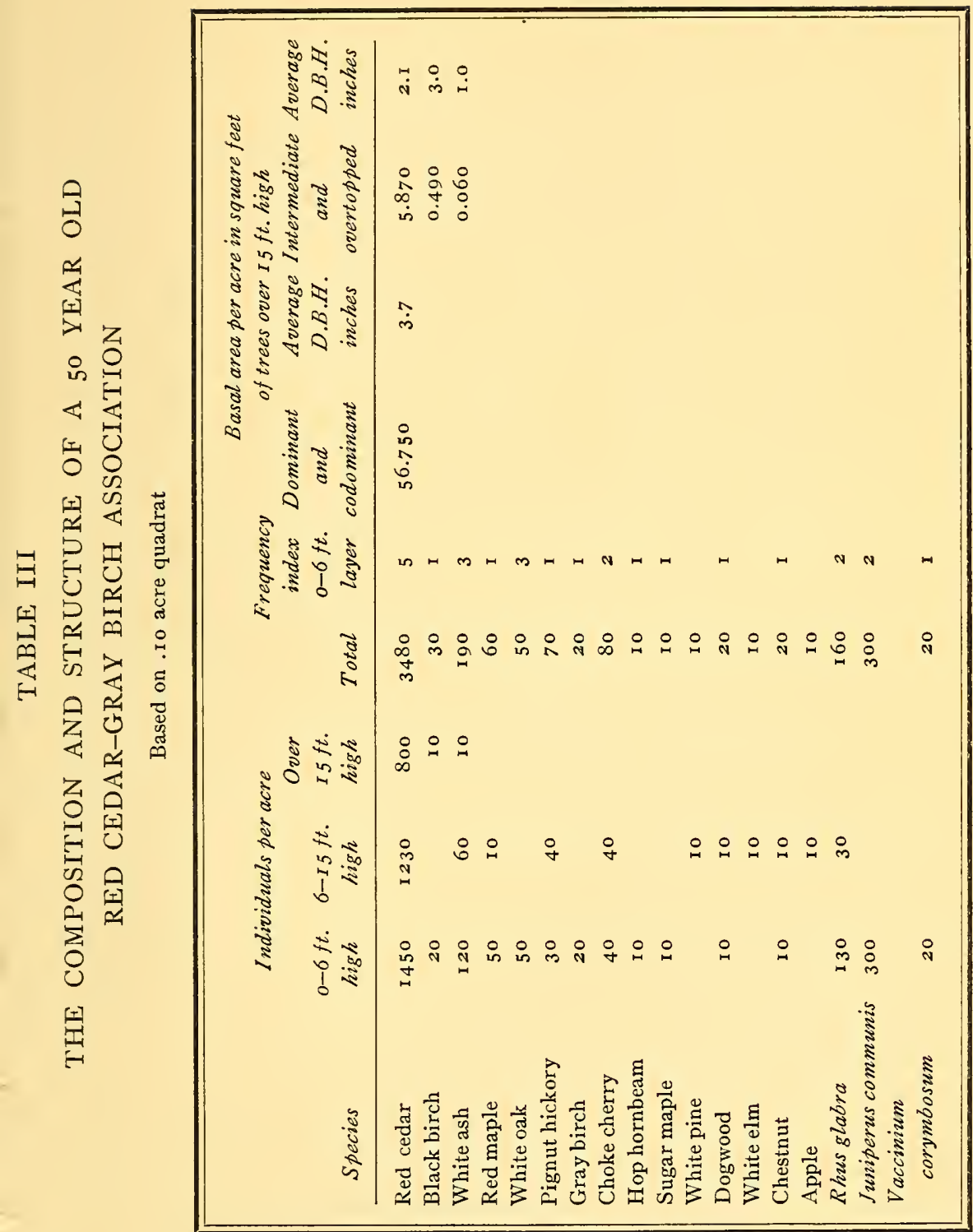




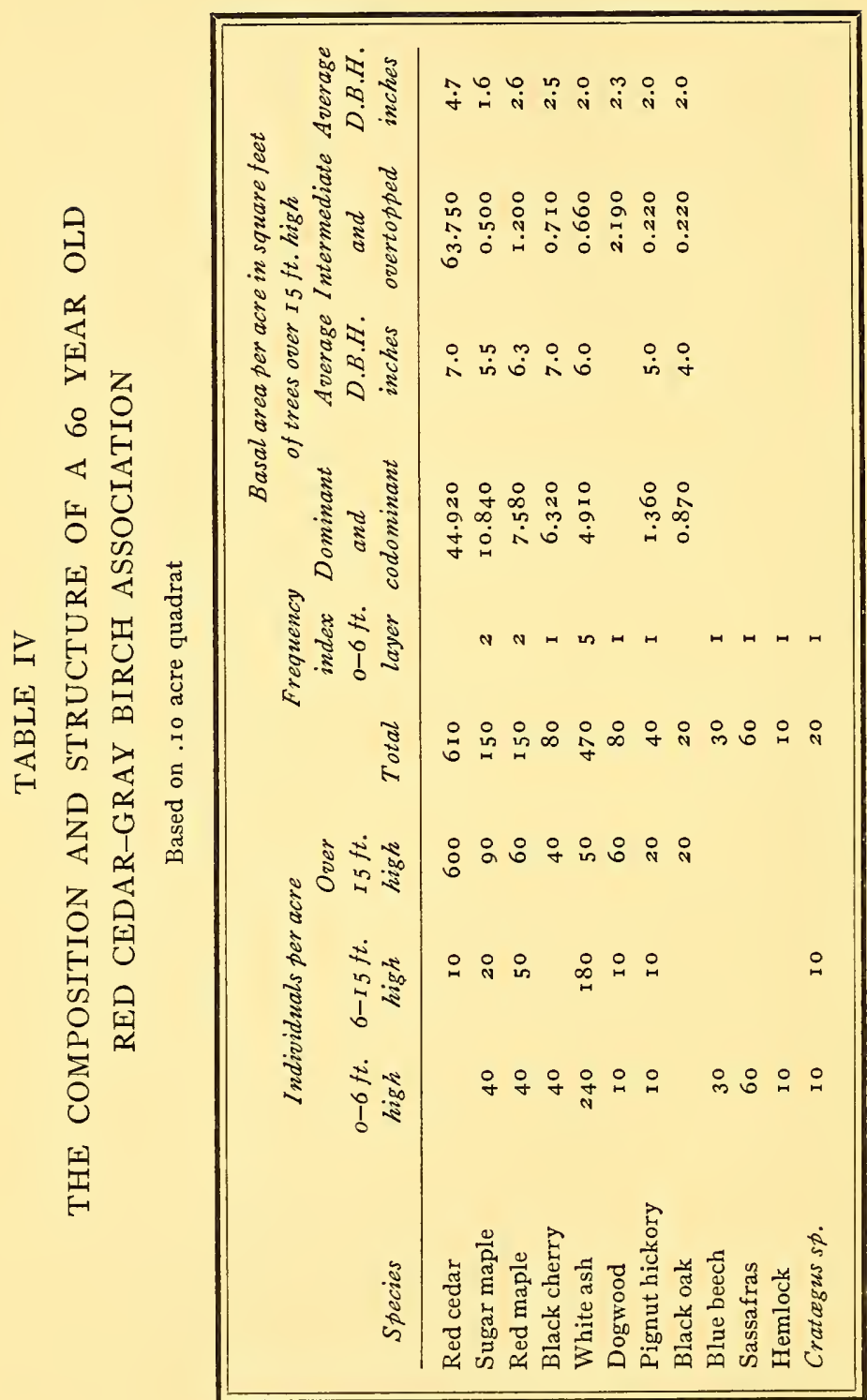




\section{TABLES}

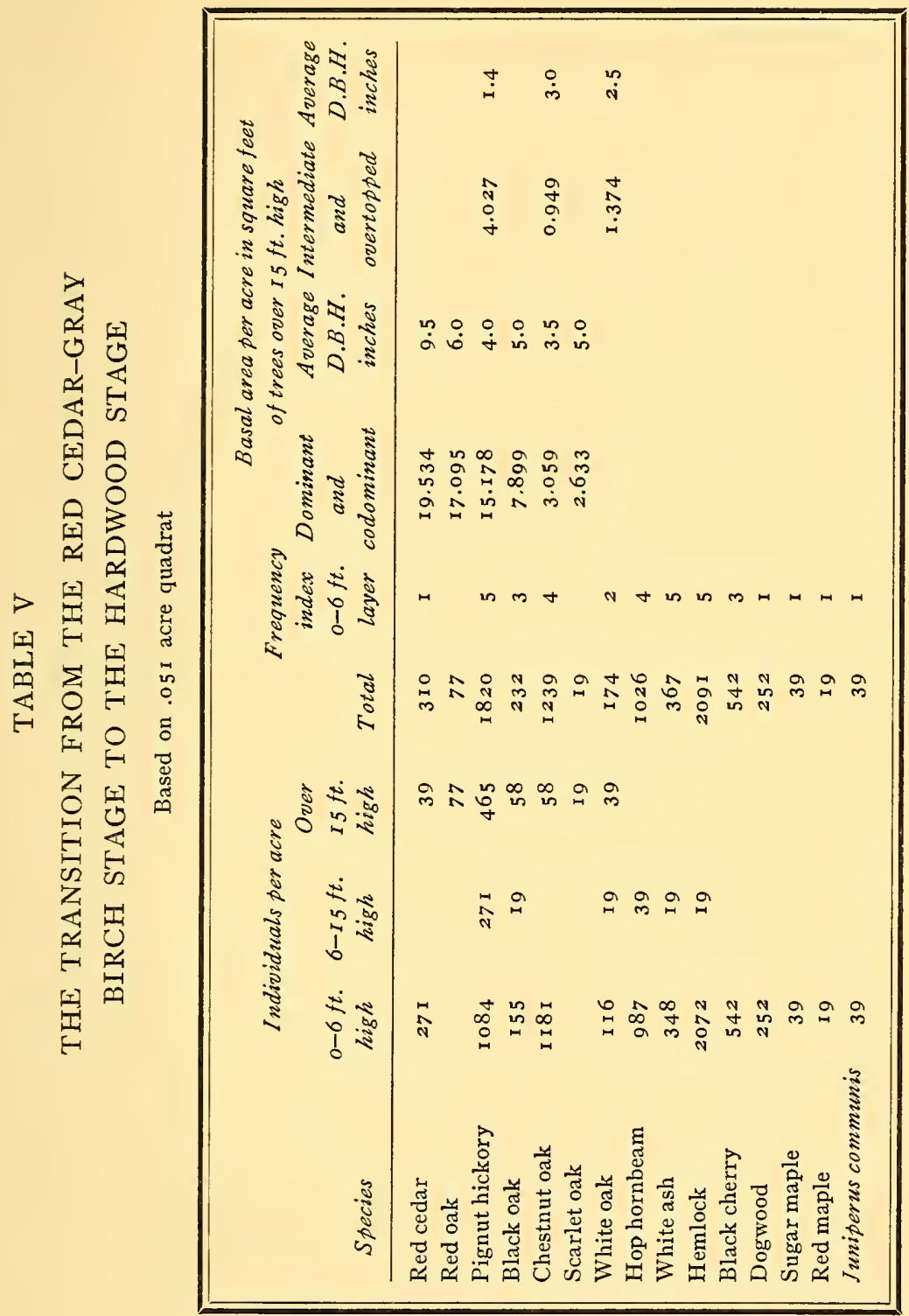




\section{UPLAND FOREST SUCCESSIONS}

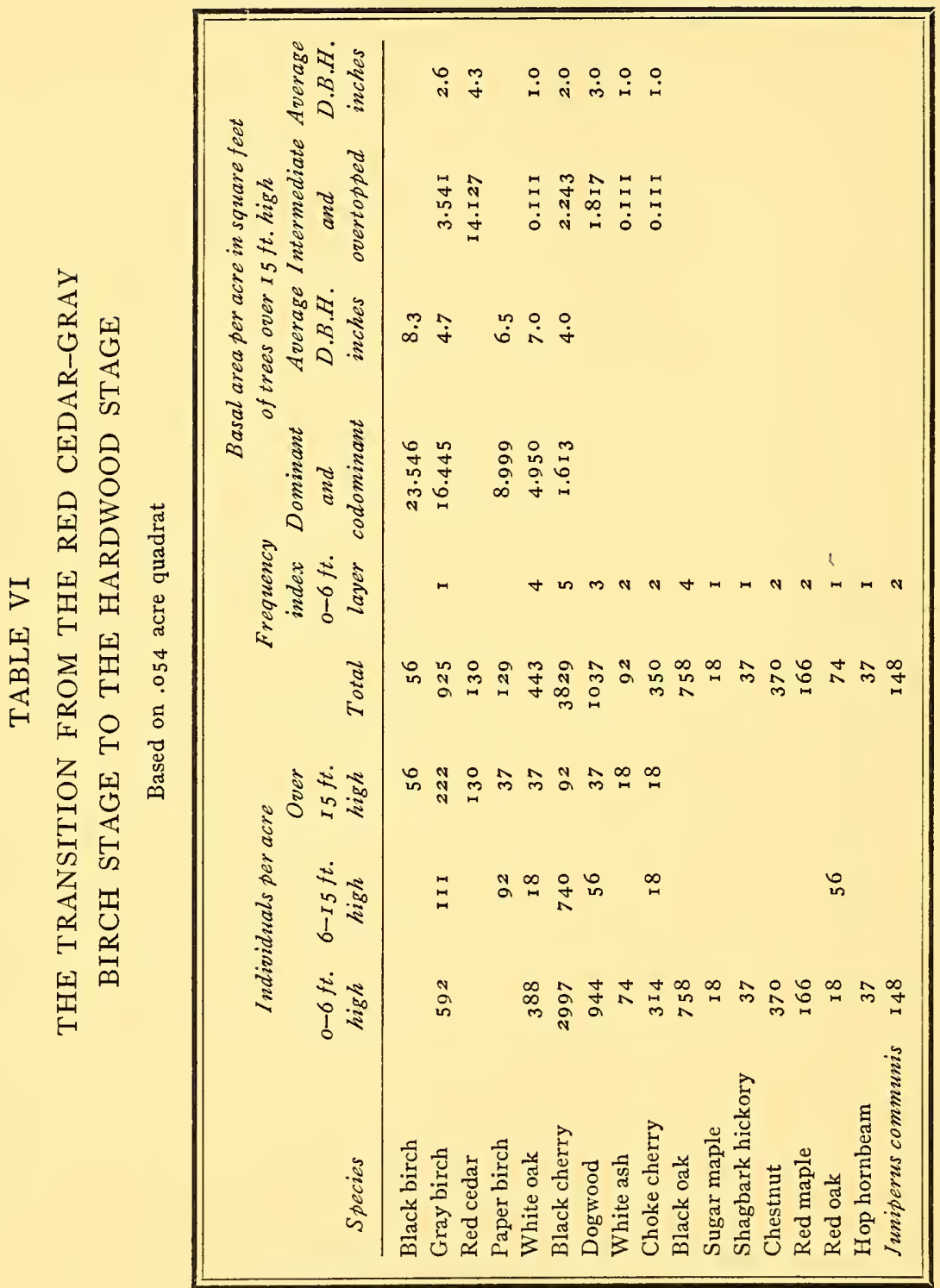


TABLES

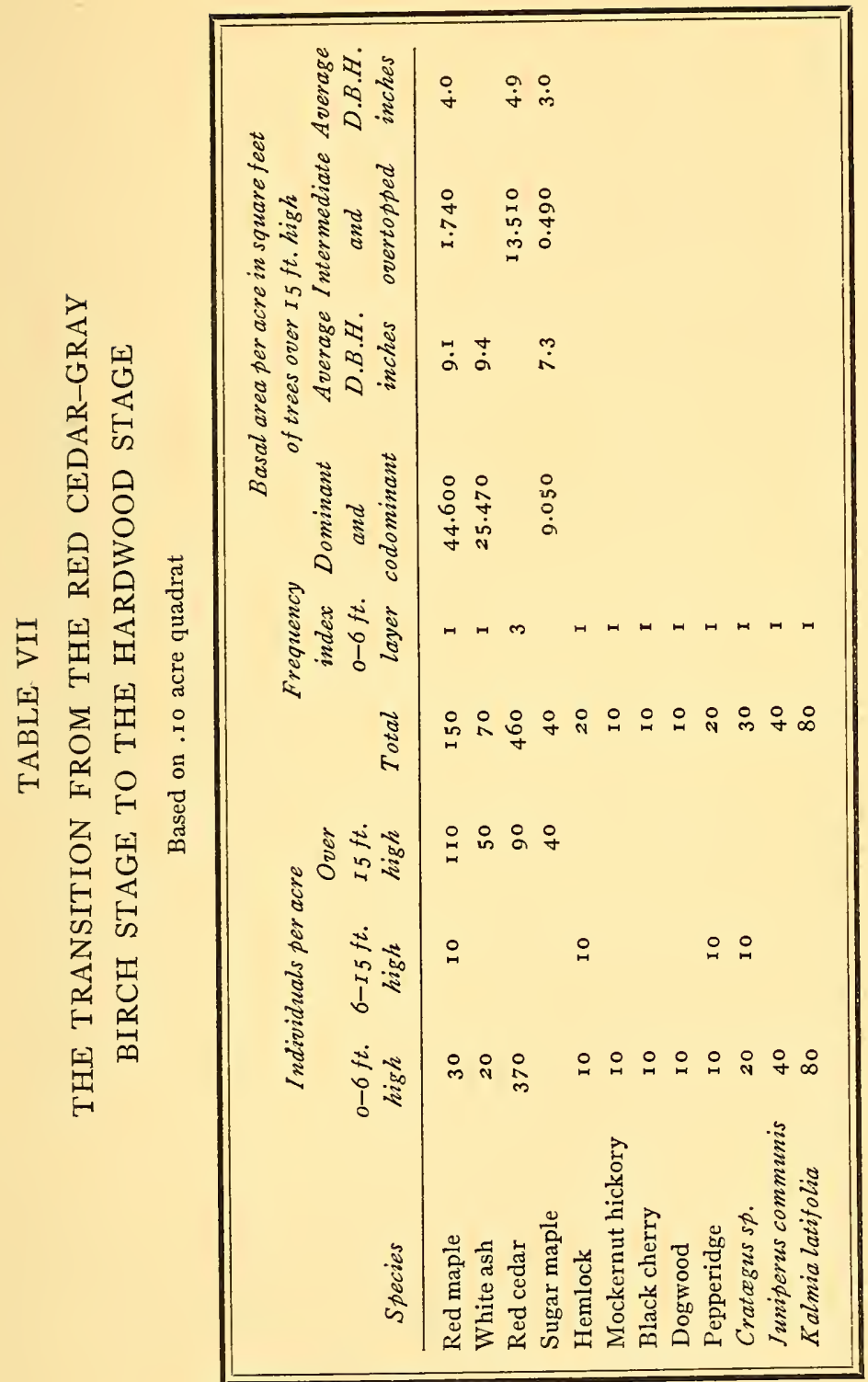




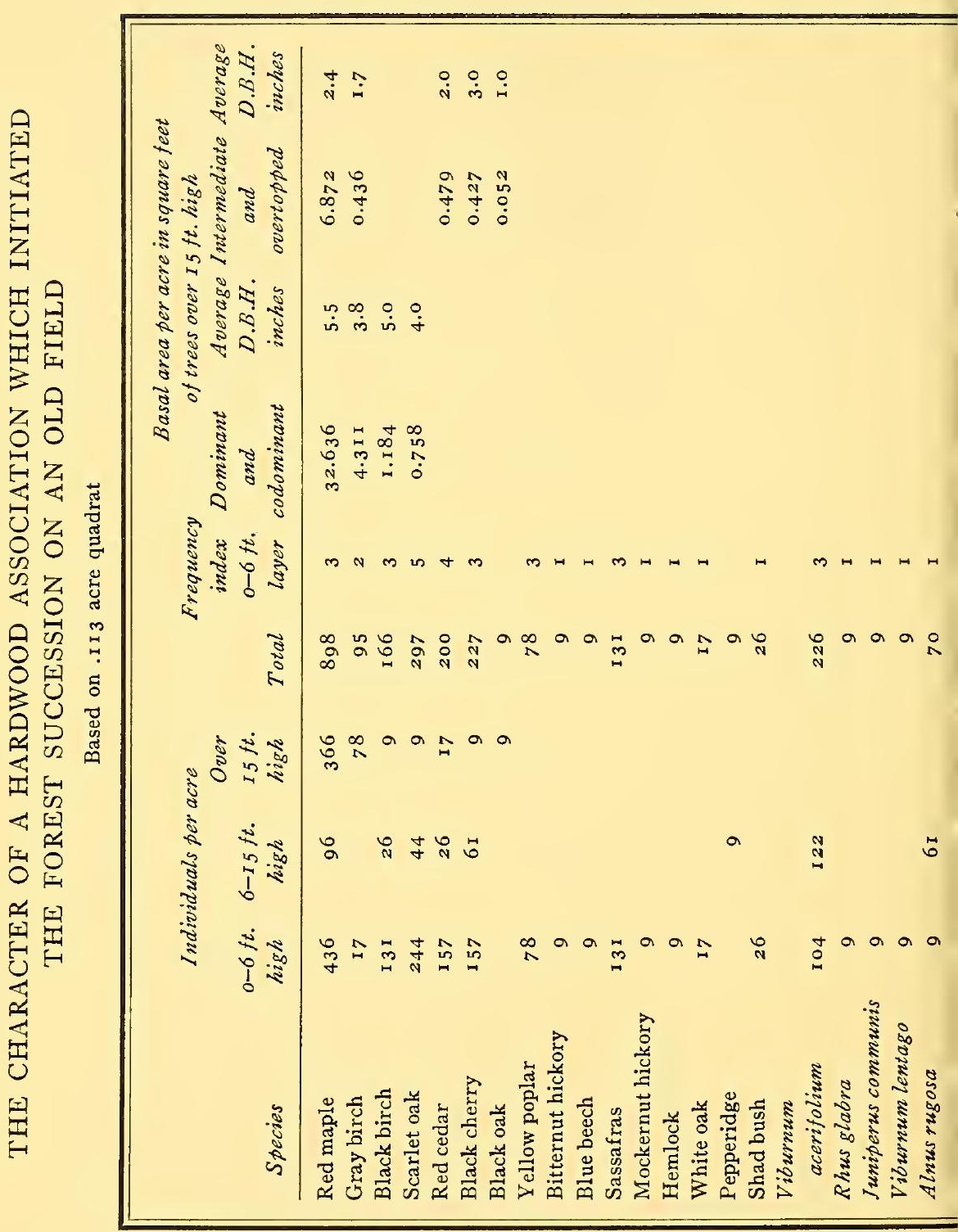




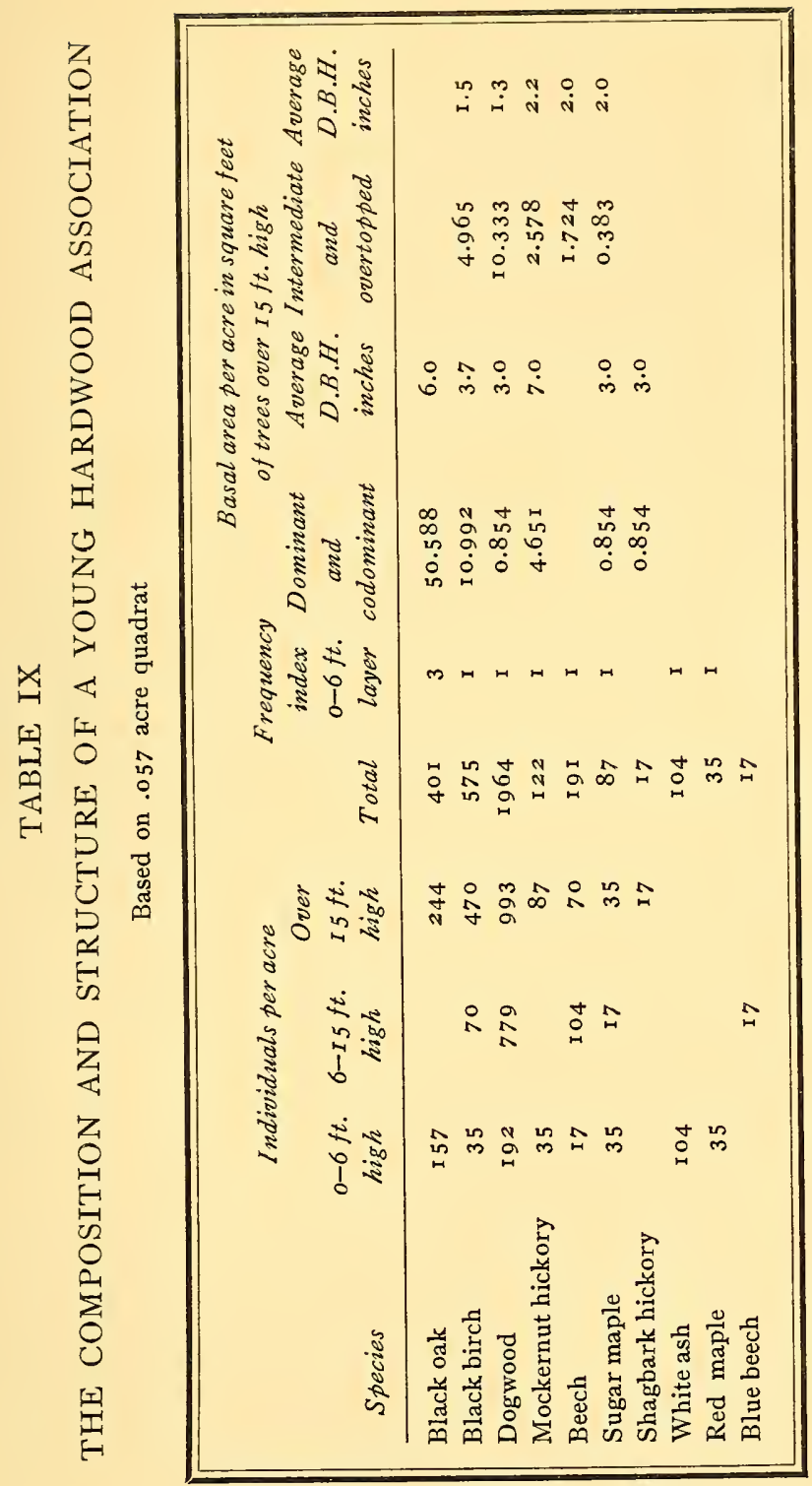




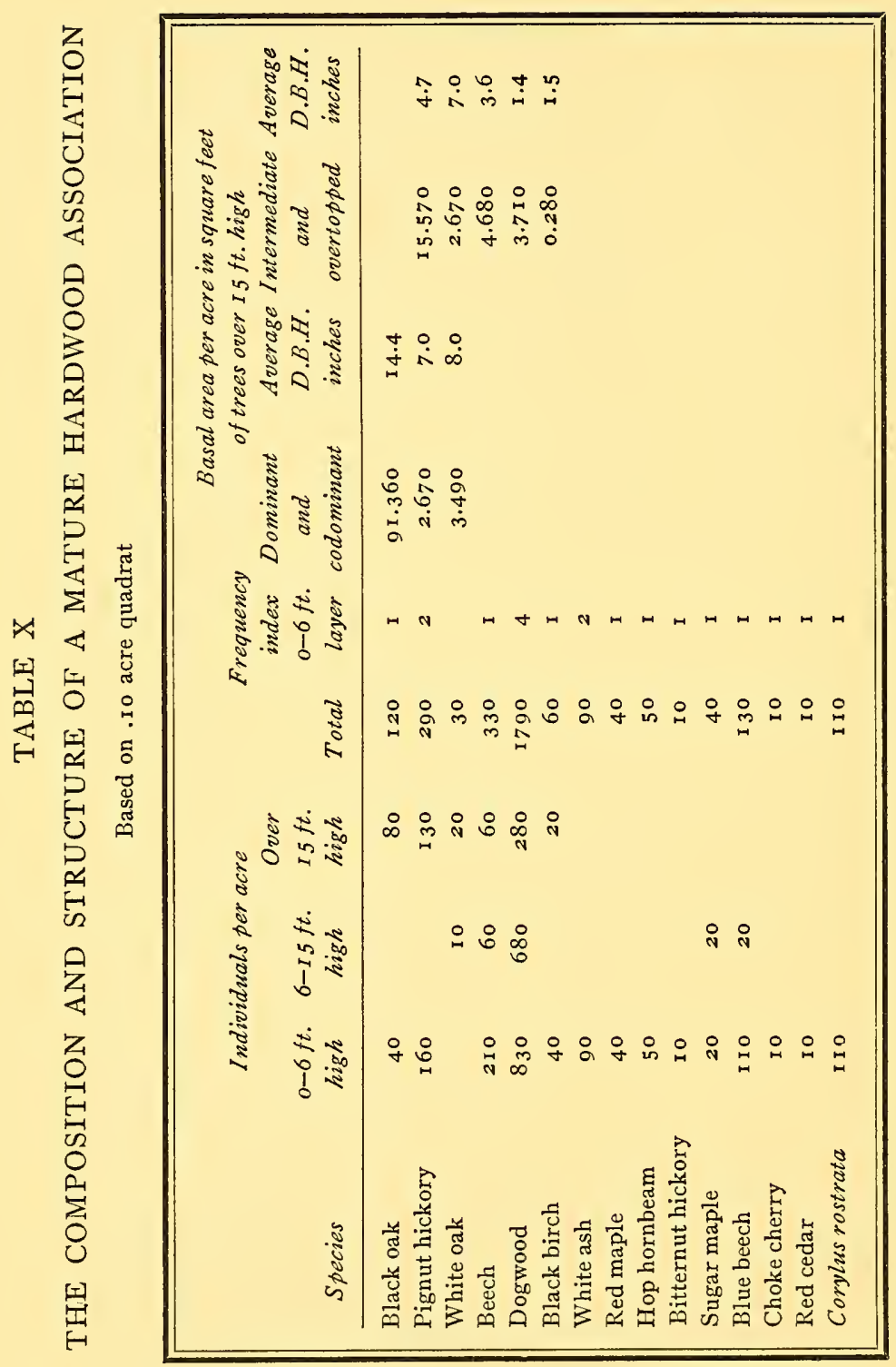




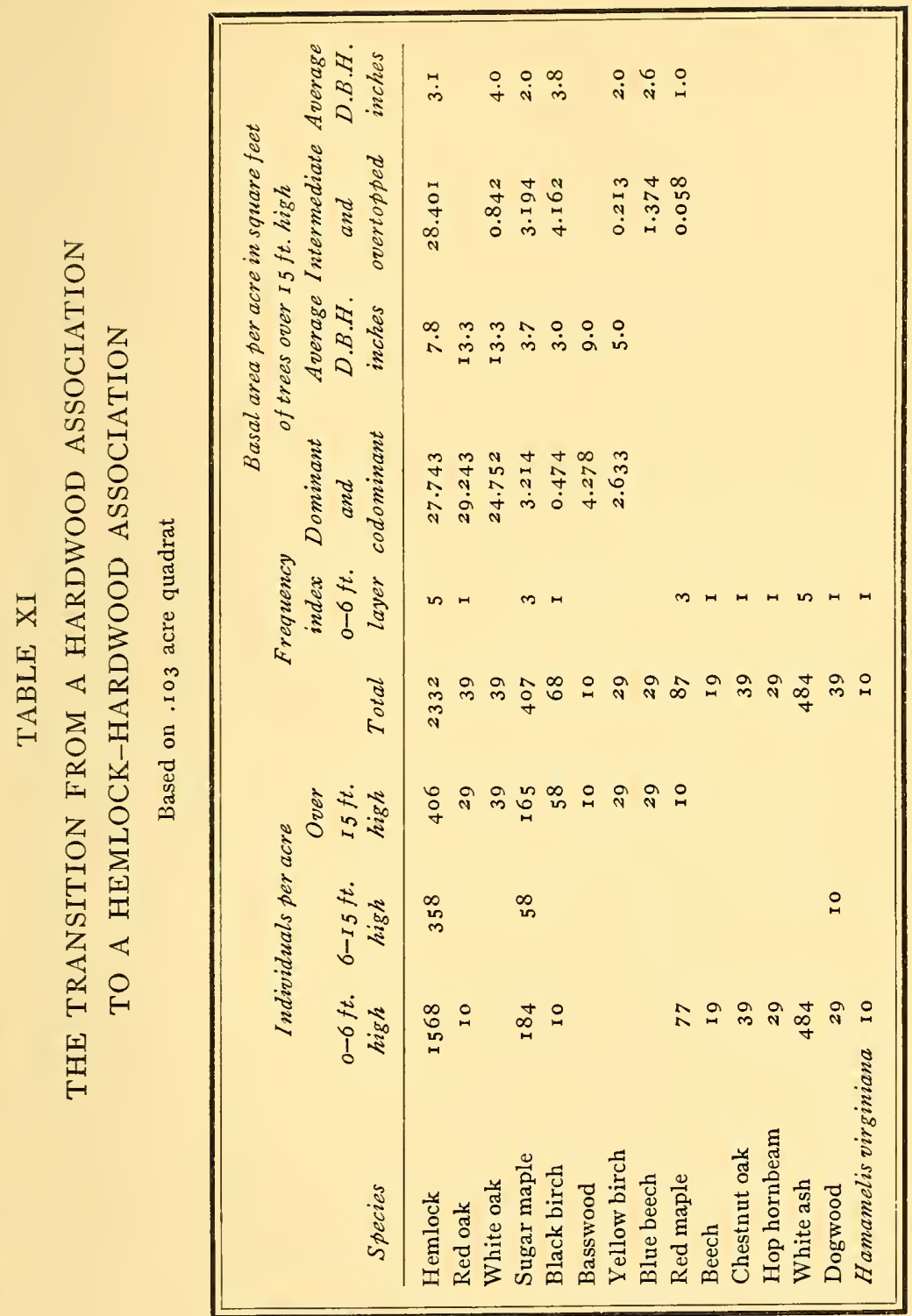




\section{UPLAND FOREST SUCCESSIONS}

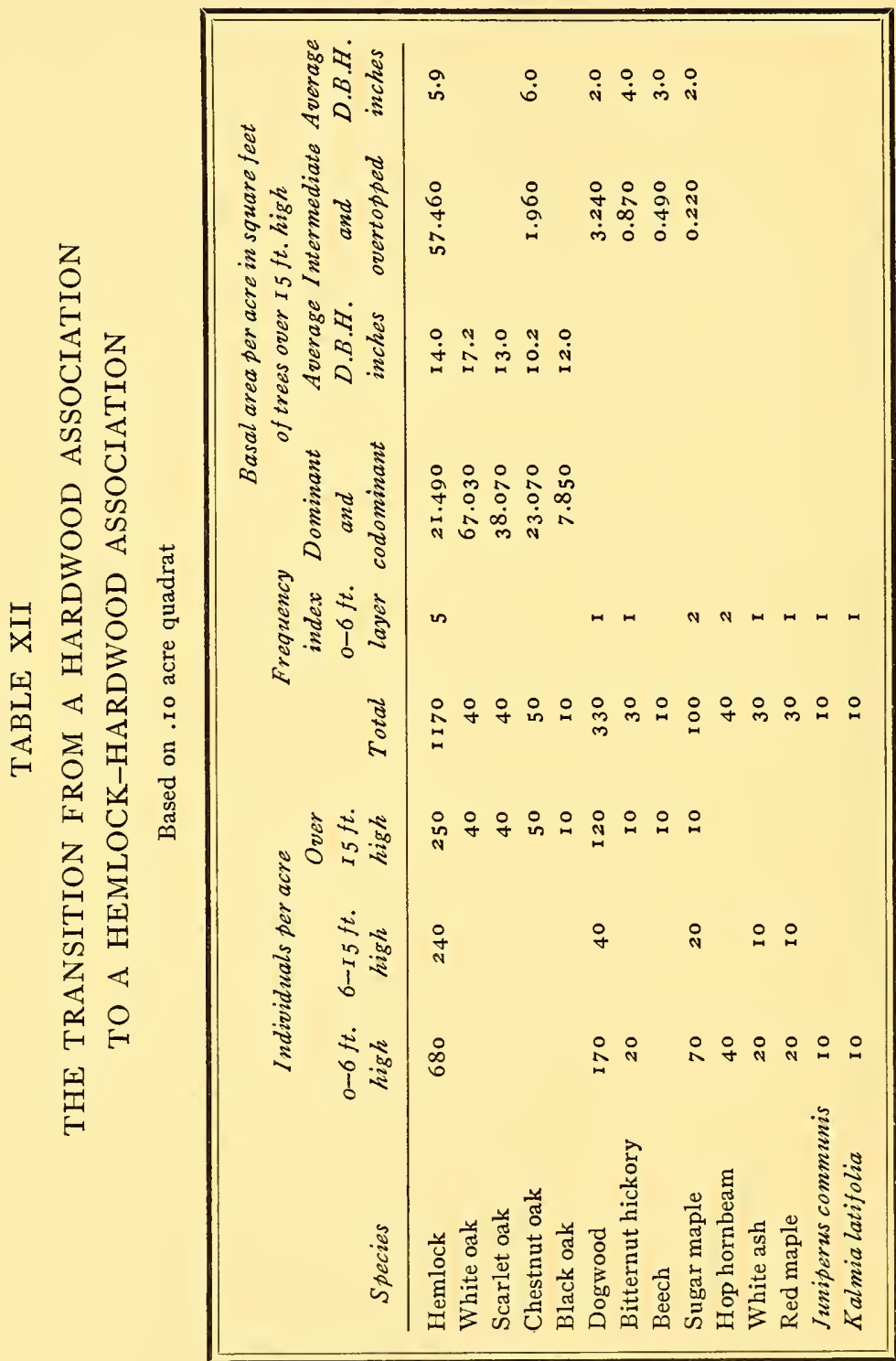


TABLES

TABLE XIII

THE EFFECT OF PARTIAL SHADE AND FULL SUNLIGHT ON THE ESTABLISHMENT OF HEMLOCK REPRODUCTION

\begin{tabular}{|c|c|c|c|c|c|c|c|c|c|c|c|}
\hline \multirow[b]{2}{*}{ Strip } & \multicolumn{10}{|c|}{ Number of quadrat } & \multirow[b]{2}{*}{ Total } \\
\hline & $I$ & 2 & 3 & 4 & 5 & 6 & 7 & 8 & 9 & IO & \\
\hline \multicolumn{12}{|c|}{ Seedlings per quadrat } \\
\hline South, shaded & 43 & 60 & 65 & 73 & 23 & Io & 2 & 3 & & & 279 \\
\hline North, exposed & I 9 & & & & & & & & & & I9 \\
\hline
\end{tabular}


UPLAND FOREST SUCCESSIONS

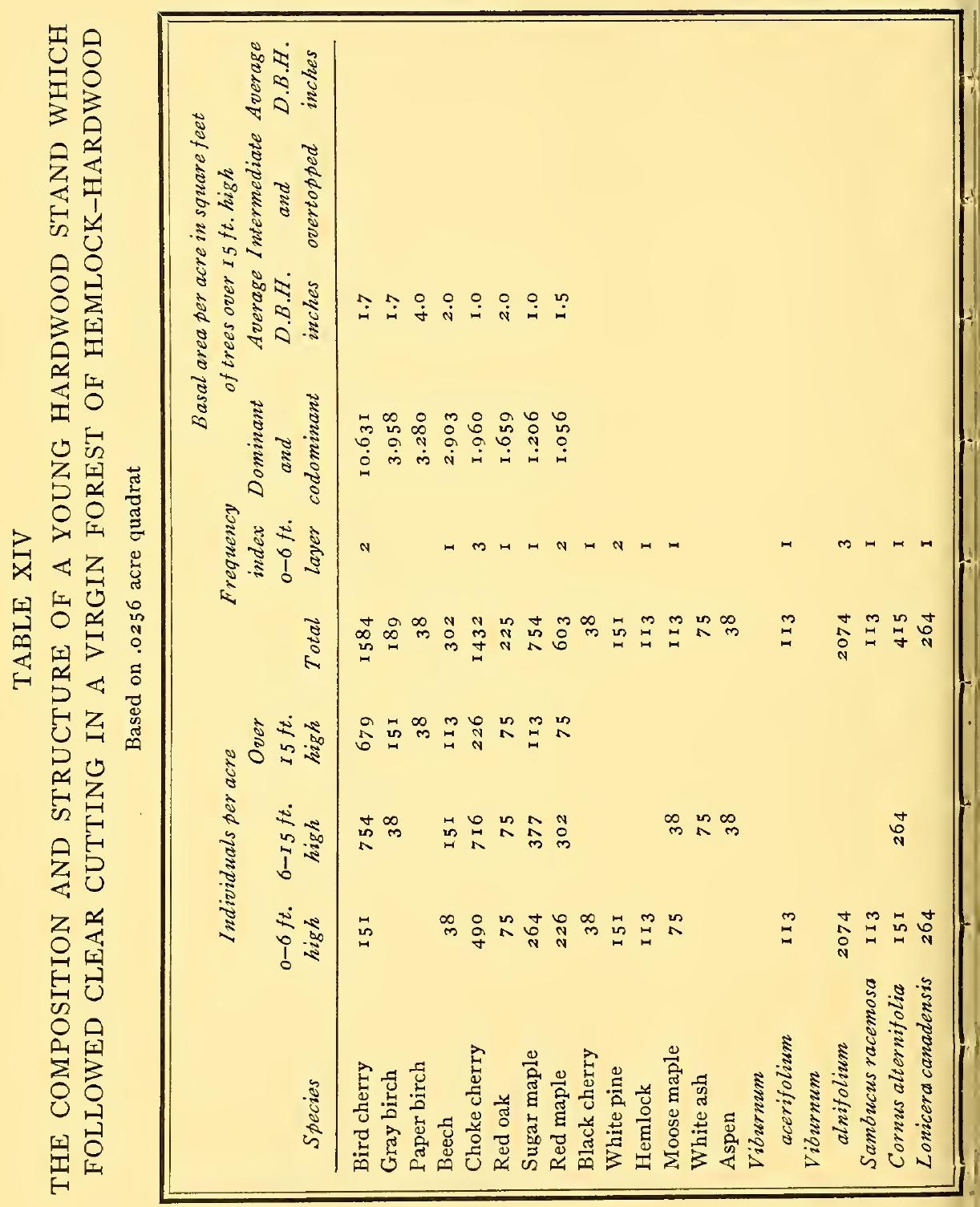




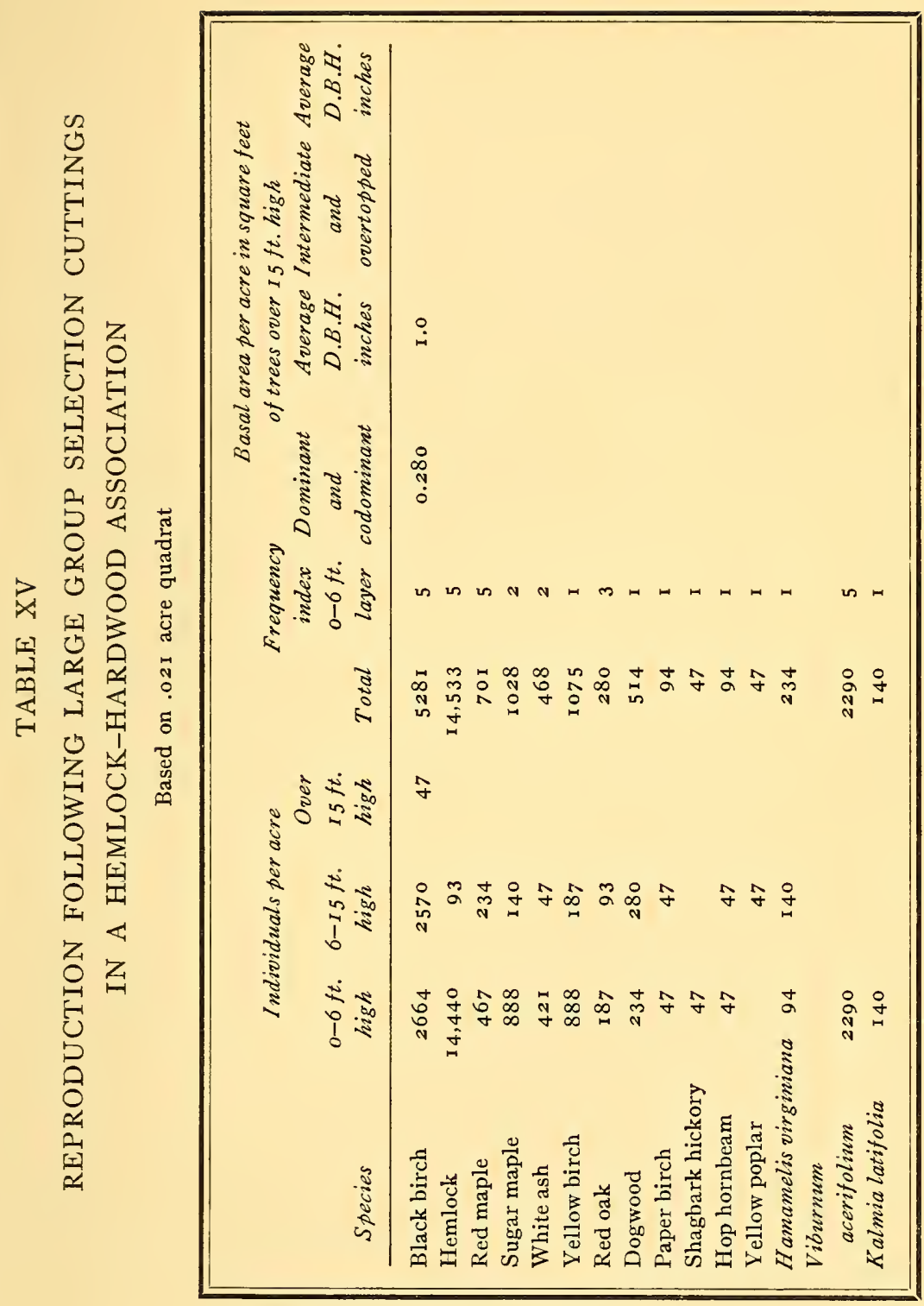




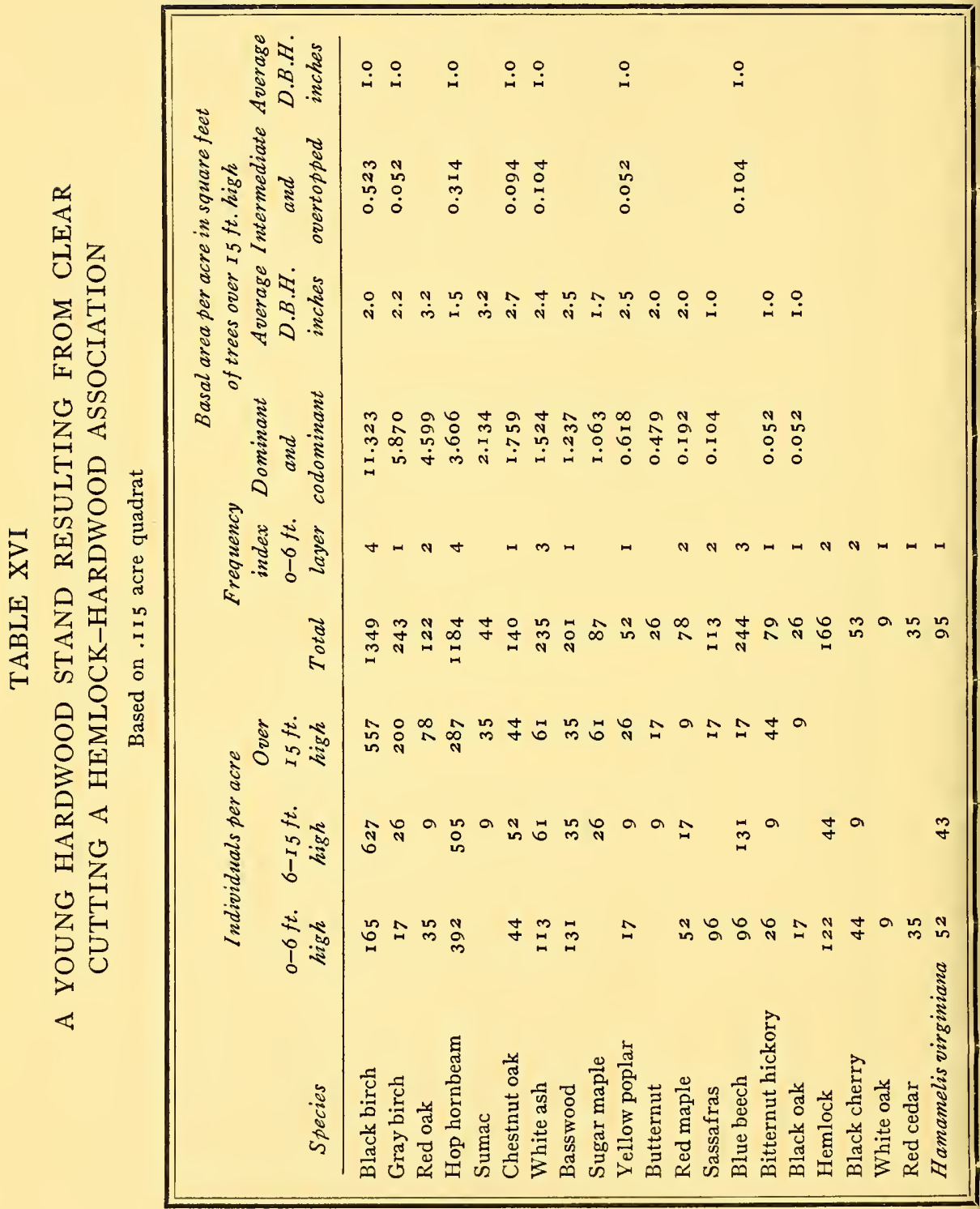




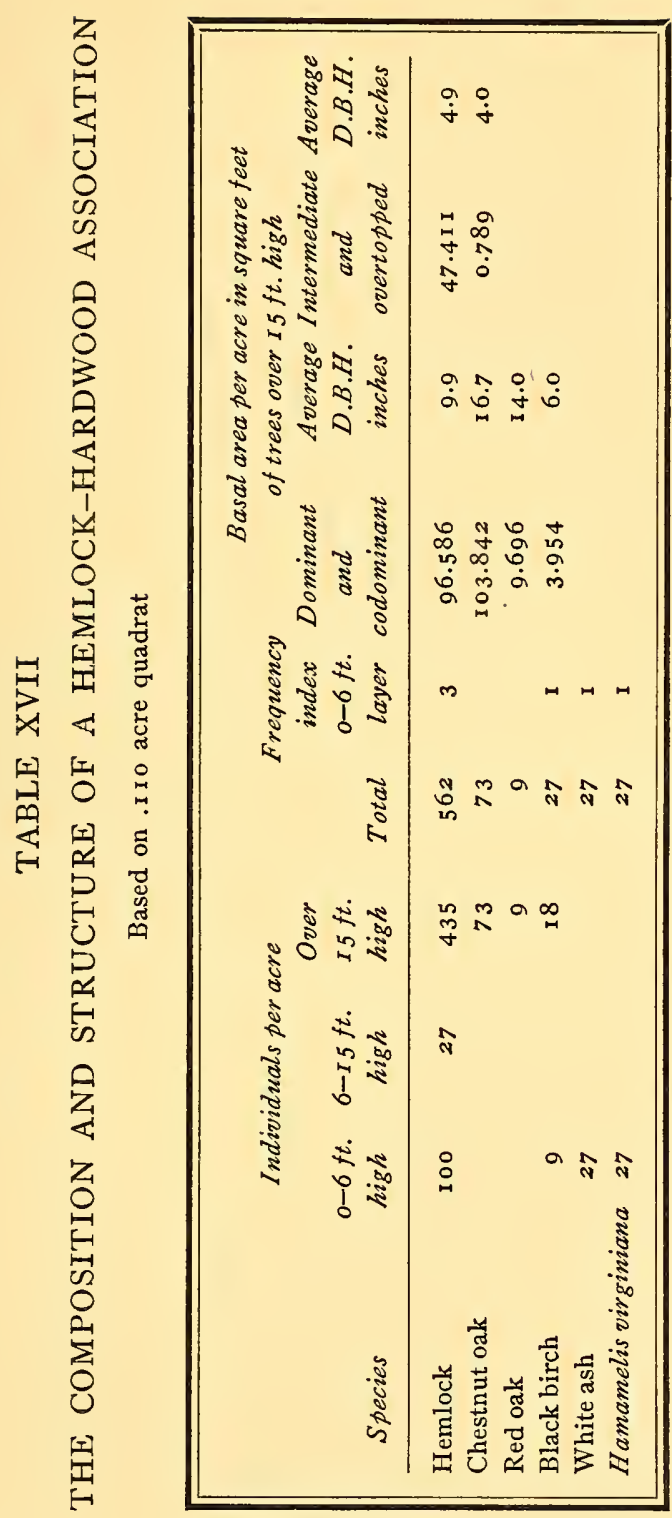


UPLAND FOREST SUCCESSIONS

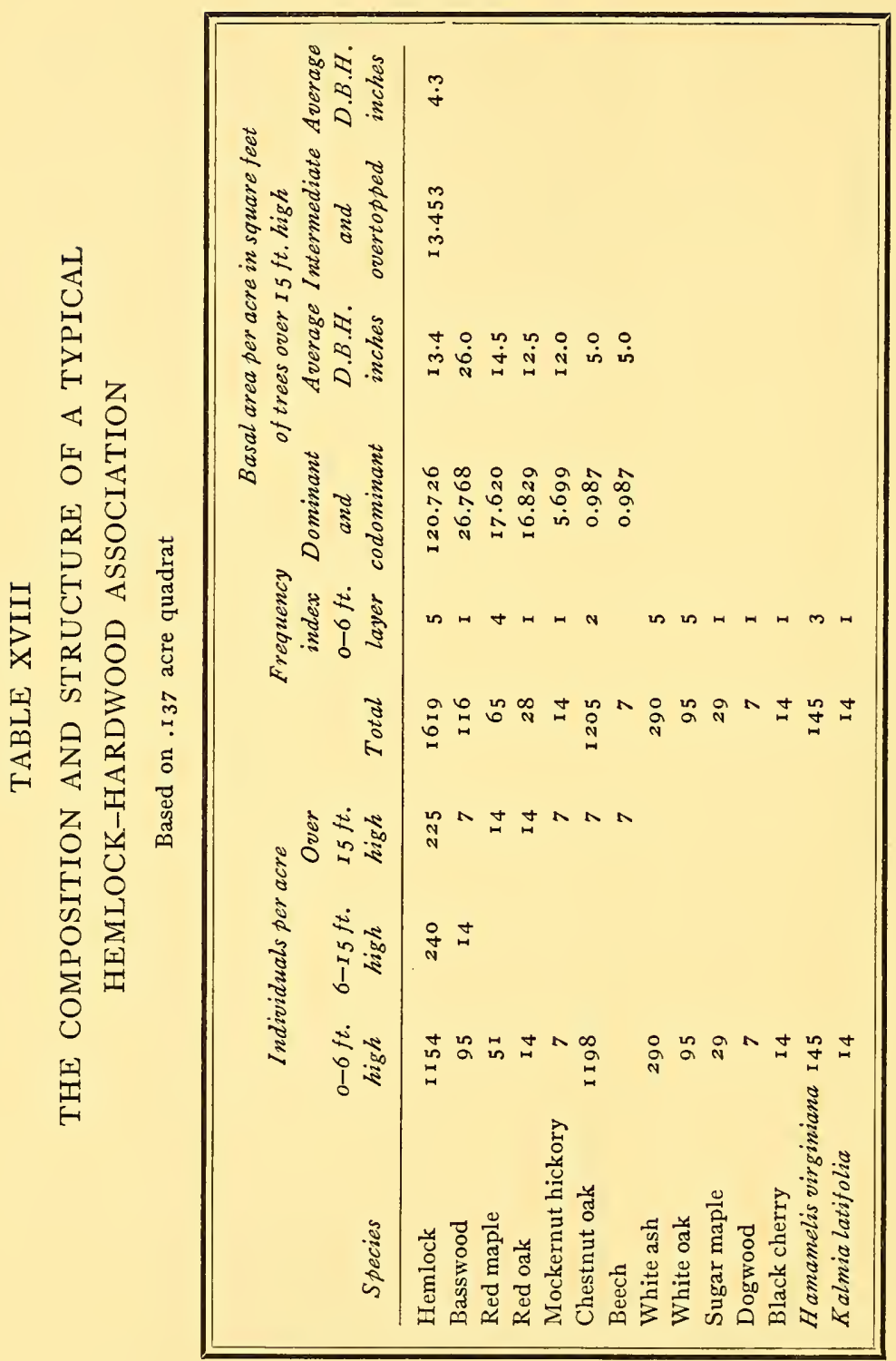


TABLES

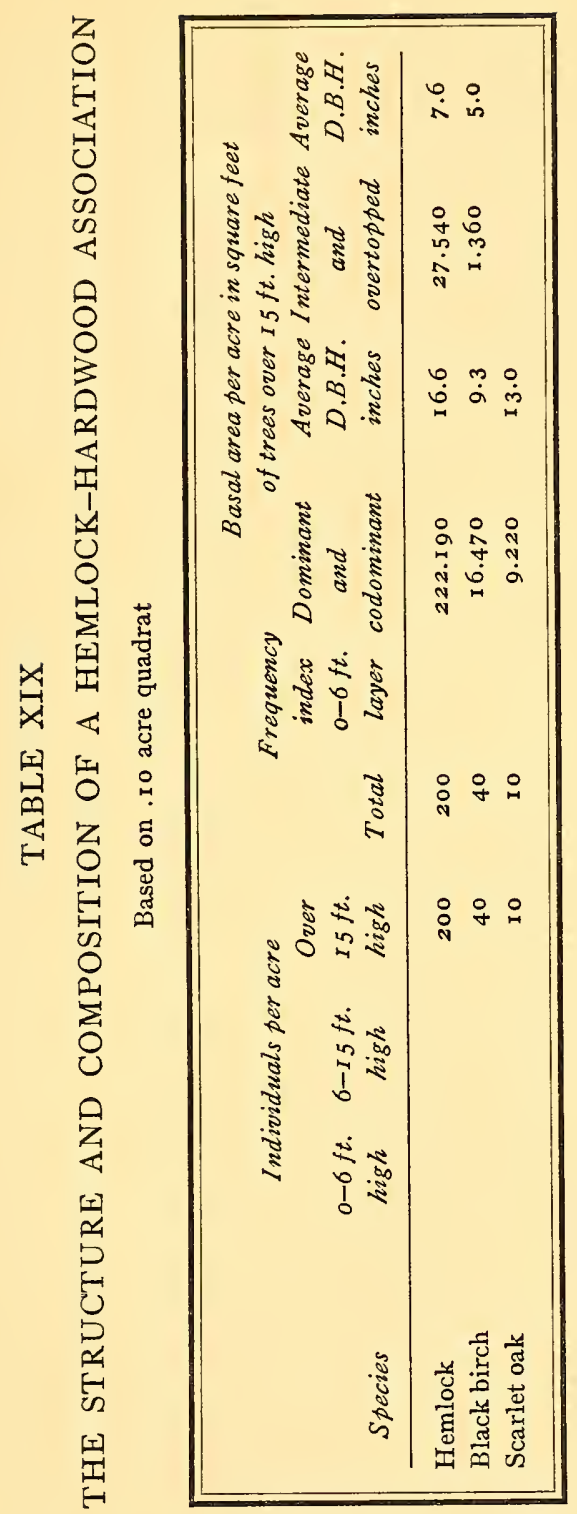




\section{LIST OF SPECIES WITH THEIR FREQUENCY OF OCCURRENCE*}

Note: The sign $\left(^{*}\right)$ following a species indicates that it was found only on the areas studied at Colebrook, Connecticut.

\begin{tabular}{|c|c|c|c|c|}
\hline \multirow[b]{2}{*}{ Scientific name } & \multirow[b]{2}{*}{ Common name } & \multicolumn{3}{|c|}{ Forest associations } \\
\hline & & $\begin{array}{l}\text { Red cedar- } \\
\text { gray birch }\end{array}$ & Hardwood & $\begin{array}{l}\text { Hemlock- } \\
\text { hardwood }\end{array}$ \\
\hline \multicolumn{5}{|l|}{ Treespecies } \\
\hline Acer pennsylvanicum & Striped maple* & & & \\
\hline Acer rubrum & Red maple & $\mathbf{S}$ & C & $\mathbf{S}$ \\
\hline Acer saccharum & Sugar maple & & $\mathrm{F}$ & $\mathrm{F}$ \\
\hline Amelanchier spp. & Shad bush & & $\mathrm{F}$ & \\
\hline Betula lenta & Black birch & $\mathbf{S}$ & $\mathrm{C}$ & $\mathbf{S}$ \\
\hline Betula lutea & Yellow birch & & $\mathrm{S}$ & $\mathrm{S}$ \\
\hline Betula papyrifera & Paper birch & & $\mathrm{S}$ & $\mathbf{S}$ \\
\hline Betula populifolia & Gray birch & $\mathrm{C}$ & $\mathbf{S}$ & \\
\hline Carpinus caroliniana & Blue beech & & $\mathrm{C}$ & $\mathbf{S}$ \\
\hline Castanea dentata & Chestnut & & $\mathbf{S}$ & \\
\hline Carya alba & Mockernut hickory & & $\mathrm{F}$ & $\mathbf{S}$ \\
\hline Carya cordiformis & Bitternut hickory & & $\mathrm{S}$ & \\
\hline Carya glabra & Pignut hickory & & C & \\
\hline Carya ovata & Shagbark hickory & & $\mathrm{S}$ & $\mathbf{S}$ \\
\hline Cornus florida & Dogwood & $\mathrm{F}$ & C & $\mathbf{S}$ \\
\hline Fraxinus americana & White ash & & $\mathbf{F}$ & $\mathrm{F}$ \\
\hline Fagus grandifolia & Beech & & $\mathrm{F}$ & $\mathrm{F}$ \\
\hline Juglans cinerea & Butternut & & $\mathbf{S}$ & \\
\hline Juniperus virginiana & Red cedar & $\mathrm{C}$ & & \\
\hline Liriodendron tulipifera & Yellow poplar & & $\mathrm{S}$ & $\mathbf{S}$ \\
\hline Nyssa sylvatica & Pepperidge & & $\mathrm{S}$ & \\
\hline Ostrya virginiana & Hop hornbeam & & $\mathrm{C}$ & $\mathbf{S}$ \\
\hline Pinus strobus & White pine & $\mathbf{S}$ & $\mathbf{S}$ & \\
\hline Populus grandidentata & Large-toothed aspen & & $\mathbf{S}$ & \\
\hline Populus tremuloides & Aspen* & & & \\
\hline Prunus pennsylvanica & Bird cherry* & & & \\
\hline Prunus serotina & Black cherry & & $\mathrm{S}$ & $\mathrm{S}$ \\
\hline Prunus virginiana & Choke cherry & $\mathrm{F}$ & $\mathbf{S}$ & \\
\hline Pyrus malus & Apple & $\mathrm{S}$ & & \\
\hline Quercus alba & White oak & & $\mathrm{C}$ & $\mathbf{F}$ \\
\hline $\begin{array}{l}\text { Quercus borealis var. } \\
\text { maxima }\end{array}$ & Red oak & & $\mathrm{C}$ & $\mathbf{F}$ \\
\hline Quercus coccinea & Scarlet oak & & $\mathrm{C}$ & $\mathrm{F}$ \\
\hline Quercus montana & Chestnut oak & & $\mathrm{C}$ & $\mathbf{F}$ \\
\hline Quercus velutina & Black oak & & $\mathrm{C}$ & $\mathrm{F}$ \\
\hline
\end{tabular}




\section{TABLES}

\section{LIST OF SPECIES WITH THEIR FREQUENCY OF OCCURRENCE (cont.)}

\begin{tabular}{|c|c|c|c|c|}
\hline \multirow[b]{2}{*}{ Scientific name } & \multirow[b]{2}{*}{ Common name } & \multicolumn{3}{|c|}{ Forestassociations } \\
\hline & & $\begin{array}{l}\text { Red cedar- } \\
\text { gray birch }\end{array}$ & Hardwood & $\begin{array}{l}\text { Hemlock- } \\
\text { hardwood }\end{array}$ \\
\hline Sassafras officinale & Sassafras & $\mathbf{S}$ & $\mathbf{S}$ & \\
\hline Tilia glabra & Basswood & & $\mathrm{S}$ & $\mathrm{F}$ \\
\hline Tsuga canadensis & Hemlock & & & $\mathrm{C}$ \\
\hline Ulmus americana & White elm & & $\mathrm{S}$ & \\
\hline \multicolumn{5}{|c|}{ Shrubby species } \\
\hline Alnus rugosa & Smooth alder & $\mathrm{S}$ & & \\
\hline Berberis vulgaris & Common barberry & $\mathbf{S}$ & & \\
\hline Celastrus scandens & Bittersweet & $\mathrm{F}$ & & \\
\hline Cornus alternifolia & $\begin{array}{l}\text { Alternate-leaved } \\
\text { dogwood }\end{array}$ & $\mathbf{S}$ & $\mathrm{S}$ & \\
\hline Corylus americana & Hazelnut & $\mathbf{S}$ & & \\
\hline Corylus rostrata & Beaked hazelnut & $\mathbf{S}$ & $\mathrm{F}$ & \\
\hline Cratagus spp. & Hawthorne & $\mathbf{S}$ & & \\
\hline Gaylussacia baccata & $\begin{array}{l}\text { Black huckle- } \\
\text { berry }\end{array}$ & $\mathrm{F}$ & $\mathrm{F}$ & \\
\hline Hamamelis virginiana & Witch hazel & & $\mathrm{C}$ & $\mathbf{F}$ \\
\hline Juniperus communis & Common juniper & $\mathrm{C}$ & & \\
\hline Kalmia latifolia & Mountain laurel & $\mathrm{F}$ & $\mathrm{F}$ & $\mathbf{S}$ \\
\hline Lonicera canadensis & $\begin{array}{l}\text { American fly } \\
\text { honeysuckle* }\end{array}$ & & & \\
\hline Lyonia ligustrina & Male berry & $\mathrm{S}$ & $\mathrm{S}$ & \\
\hline Myrica asplenifolia & Sweet fern & $\mathrm{C}$ & & \\
\hline Myrica carolinensis & Bayberry & $\mathrm{C}$ & & \\
\hline Rhus copallina & Dwarf sumac & $\mathrm{C}$ & & \\
\hline Rhus glabra & Smooth sumac & $\mathrm{C}$ & & \\
\hline Rhus toxicodendron & Poison ivy & $F$ & $\mathrm{~F}$ & \\
\hline Rhus typhina & Staghorn sumac & $\mathrm{F}$ & & \\
\hline Rosa humilis & Rose & $\mathrm{F}$ & & \\
\hline Rubus allegheniensis & $\begin{array}{l}\text { High bush black- } \\
\text { berry }\end{array}$ & $\mathrm{F}$ & & \\
\hline Rubus cuneifolius & Sand blackberry & $\mathrm{F}$ & & \\
\hline Rubus hispidus & Swamp dewberry & & $\mathrm{F}$ & $\mathrm{S}$ \\
\hline Kubus occidentalis & Black raspberry & $\mathrm{F}$ & & \\
\hline Rubus villosus & Dewberry & $\mathrm{C}$ & $\mathrm{S}$ & \\
\hline Sambucus racemosa & $\begin{array}{l}\text { Red-berried } \\
\text { elder* }\end{array}$ & & & \\
\hline
\end{tabular}




\section{LIST OF SPECIES WITH THEIR FREQUENCY \\ OF OCCURRENCE (cont.)}

\begin{tabular}{|c|c|c|c|c|}
\hline \multirow{2}{*}{ Scientific name } & \multirow{2}{*}{ Common name } & \multicolumn{3}{|c|}{ Forest associations } \\
\hline & & Red cedar- & & Hemlock- \\
\hline Vaccinium corymbosum & High blueberry & $\mathrm{F}$ & $\mathrm{F}$ & \\
\hline $\begin{array}{l}\text { Vaccinium } \\
\text { pennsylvanicum }\end{array}$ & Low sweet blueberry & ry $F$ & $\mathrm{~F}$ & \\
\hline Vaccinium vacillans & Low late blueberry & $F$ & $\mathrm{~F}$ & \\
\hline Viburnum acerifolium & $\begin{array}{l}\text { Maple-leaved } \\
\text { viburnum }\end{array}$ & S & $\mathrm{C}$ & $\mathrm{F}$ \\
\hline Viburnum lentago & Sweet viburnum & & $\mathrm{S}$ & \\
\hline $\begin{array}{l}\text { Viburnum alnifolium } \\
\text { Herbaceous sp }\end{array}$ & $\begin{array}{l}\text { Hobble bush* } \\
\text { eies }\end{array}$ & & & \\
\hline Actoea alba & White baneberry & & $\mathbf{S}$ & \\
\hline Adiantum pedatum & Maidenhair fern & & $\mathrm{F}$ & \\
\hline Amphicarpa monoica & Hog peanut & & $\mathbf{F}$ & \\
\hline Andropogon scoparius & Bunch grass & $\mathrm{F}$ & & \\
\hline Anemone quinquefolia & Wood anemone & & $\mathbf{S}$ & \\
\hline $\begin{array}{l}\text { Apocynum } \\
\text { androsamifolium }\end{array}$ & Spreading dogbane & $\mathrm{S}$ & & \\
\hline Aralia nudicaulis & Wild sarsaparilla & & $\mathrm{C}$ & $\mathbf{S}$ \\
\hline Arisama triphyllum & Jack-in-the-pulpit & & $\mathrm{S}$ & \\
\hline Aspidium marginale & $\begin{array}{l}\text { Marginal shield } \\
\text { fern }\end{array}$ & & $\mathbf{F}$ & \\
\hline Aspidium noveboracense & New York fern & & $\mathbf{F}$ & \\
\hline Asplenium felix-femina & Lady fern & & $\mathbf{F}$ & \\
\hline Aster spp. & Aster & $\mathrm{F}$ & $\mathrm{F}$ & \\
\hline Carex spp. & Sedge & $\mathbf{F}$ & $\mathrm{F}$ & \\
\hline Chimaphila maculata & $\begin{array}{l}\text { Spotted } \\
\text { wintergreen }\end{array}$ & & $\mathrm{S}$ & $\mathrm{S}$ \\
\hline Chimaphilos umbellata & Prince's pine & & $\mathrm{S}$ & $\mathbf{S}$ \\
\hline Collinsonia canadensis & Rich weed & & $\mathrm{S}$ & \\
\hline Cypripedium acaule & $\begin{array}{l}\text { Stemless lady's } \\
\text { slipper }\end{array}$ & & $\mathrm{S}$ & \\
\hline Dicksonia punctilobula & Hay-scented fern & $\mathrm{F}$ & $\mathbf{F}$ & \\
\hline Epipactis pubescens & $\begin{array}{l}\text { Rattlesnake } \\
\text { plantain }\end{array}$ & & $\mathrm{S}$ & $\mathrm{S}$ \\
\hline Geranium maculatum & Wild cranesbill & & $\mathbf{F}$ & \\
\hline Hepatica triloba & Hepatica & & $\mathbf{F}$ & \\
\hline Hieracium spp. & Hawkweed & $\mathrm{C}$ & $\mathrm{S}$ & \\
\hline
\end{tabular}


LIST OF SPECIES WITH THEIR FREQUENCY

OF OCCURRENCE (cont.)

\begin{tabular}{|c|c|c|c|c|}
\hline \multirow[b]{2}{*}{ Scientific name } & \multirow[b]{2}{*}{ Common name } & \multicolumn{3}{|c|}{ Forest associations } \\
\hline & & $\begin{array}{l}\text { Red cedar- } \\
\text { gray birch }\end{array}$ & Hardwood & $\begin{array}{l}\text { Hemlock- } \\
\text { hardwood }\end{array}$ \\
\hline Hypoxis hirsuta & Star grass & & $\mathrm{S}$ & \\
\hline $\begin{array}{l}\text { Lycopodium } \\
\text { complanatum }\end{array}$ & Club moss & & $\mathrm{F}$ & $S$ \\
\hline Lycopodium clavatum & Club moss & & $\mathrm{S}$ & \\
\hline Lycopodium obscurum & Club moss & & $\mathrm{F}$ & $\mathbf{S}$ \\
\hline Lysmachia quadrifolia & Loosestrife & & $\mathrm{C}$ & \\
\hline Maionthemum canadense & $\begin{array}{l}\text { Wild lily of } \\
\text { the valley }\end{array}$ & & $\mathrm{C}$ & $\mathrm{F}$ \\
\hline Medeola virginiana & $\begin{array}{l}\text { Indian cucumber } \\
\text { root }\end{array}$ & & $\mathrm{F}$ & \\
\hline Melampyrum linare & Cow wheat & & $\mathrm{C}$ & $\mathrm{S}$ \\
\hline Mitchella repens & Partridge berry & & $\mathrm{C}$ & C \\
\hline Monotropa uniflora & Indian pipe & & $\mathrm{F}$ & $\mathrm{F}$ \\
\hline Oakesia sessilifolia & Oakesia & & $\mathrm{C}$ & $S$ \\
\hline Onoclea sensibilis & Sensitive fern & & $\mathrm{S}$ & \\
\hline Osmunda cinnamomea & Cinnamon fern & & $\mathrm{S}$ & \\
\hline Osmunda claytoniana & Interrupted fern & & $\mathrm{F}$ & \\
\hline Osmunda regalis & Royal fern & & $\mathrm{S}$ & \\
\hline $\begin{array}{l}\text { Phegopteris } \\
\text { hexagonoptera }\end{array}$ & Beech fern & & $S$ & \\
\hline Phytolacca decandra & Common pokeberry & $\mathrm{F}$ & $\mathrm{S}$ & \\
\hline $\begin{array}{l}\text { Polystichum } \\
\text { acrostichoides }\end{array}$ & Christmas fern & & $\mathrm{C}$ & $\mathrm{C}$ \\
\hline Prenanthes trifoliolatc & Gall-of-the-earth & & $\mathrm{F}$ & $\mathrm{S}$ \\
\hline Pteris aquilina & Brake & $\mathrm{C}$ & $\mathrm{F}$ & \\
\hline Pyrola americana & Shin leaf & & F & $\mathrm{S}$ \\
\hline Rumex acetosella & Field sorrel & $\mathrm{F}$ & & \\
\hline Smilacina racemosa & False spikenard & & $\mathrm{F}$ & \\
\hline Smilax glauca & Cat brier & & $\mathrm{F}$ & \\
\hline Smilax rotundifolia & Green brier & $\mathrm{S}$ & $\mathrm{F}$ & \\
\hline Solidago spp. & Goldenrod & $\mathrm{C}$ & $\mathrm{F}$ & \\
\hline Trientalis americana & Star flower & & $\mathrm{F}$ & \\
\hline Uvularia perfoliata & Bellwort & & $\mathrm{C}$ & \\
\hline Verbascum thapsus & Common mullein & $\mathrm{C}$ & & \\
\hline Veronica officinalis & Common speedwell & $\mathrm{C}$ & $\mathrm{F}$ & $\mathrm{S}$ \\
\hline
\end{tabular}




\section{REFERENCES}

Bidwell, P. W., and Falconer, J. I. (1925.) History of agriculture in the northern United States. Carnegie Inst. Pub. No. 358.

Christopherson, E. (1925.) Soil reaction and plant distribution in the Sylene National Park, Norway. Trans. of the Conn. Acad. of Arts and Sci. 27 : 471-577.

Clements, F. E. (I916.) Plant succession. Carnegie Inst. Pub. No. 242.

Cowles, H. C. (I90I.) The physiographic ecology of Chicago and vicinity. Bot. Gaz. $31: 73-108,145-182$.

Durland, W. D. (1922.) Results of an experiment in reproducing hardwood stands under the shelter wood method. Jour. of For. $20: 869-87 \mathrm{I}$.

Frothingham, E. H. ( 19 12.) The second growth hardwoods in Connecticut. U.S.D.A. Forest Service Bull. 96.

Frothingham, E. H. (I9I5.) The eastern hemlock. U.S.D.A. Bull. I 52.

Gleason, H. A. (1920.) Some applications of the quadrat method. Bull. of the Torrey Bot. Club $47: 2 \mathrm{I}-33$.

Harper, R. M. (I9I2.) The diverse habitats of the eastern red cedar and their interpretation. Torreya $I 2: 7$.

Hawes, A. F., and Hawley, R. C. (1909.) Forest survey of Litchfield and New Haven counties, Connecticut. Conn. Agr. Exp. Sta. Bull. 162.

Leffelman, L. J., and Hawley, R. C. (1925.) The treatment of advance growth arising as a result of thinnings and shelter wood cuttings. Yale Univ. School of Forestry Bull. 15 .

Marshall, Robert. (1927.) The growth of hemlock before and after release from suppression. Harvard Forest Bull. I I.

Merrill, P. H., and Hawley, R. C. (I924.) Hemlock: its place in the silviculture of the southern New England forest. Yale Univ. School of Forestry Bull. I 2.

Moore, B., Richards, H. M., Gleason, H. A., and Stout, A. B. (I924.) Hemlock and its environment, I. Field records. Bull. of the New York Bot. Garden I2: 325-350, I $3-\mathrm{S}$.

Mowat, E. L. (1927.) A study of advance reproduction in the even aged, unthinned Connecticut hardwood stand. Unpublished MS.

Nichols, G. E. ( I 9 I 3.) The vegetation of Connecticut: virgin forests. Torreya I3: 9 .

Nichols, G. E. (1923.) A working basis for the ecological classification of plant communities. Ecology 4: I I-23; I 54-I 79.

Robinson, B. L., and Fernald, M. L. (1908.) Gray's new manual of botany. Seventh edition.

Sargent, C. S. (1922.) Manual of the trees of North America. Second edition.

Society of American Foresters. (I 9 I 7.) Forest terminology; terms in forestry compiled by a committee of the Society of American Foresters. Jour. of For. 15:71-10I.

Tarbox, E. E. (1924.) Quality and growth of white pine as influenced by density, site, and associated species. Harvard Forest Bull. 7 .

Toumey, J. W., and Neethling, E. J. (1924.) Insolation: a factor in the regeneration of certain conifers. Yale Univ. School of Forestry Bull. I I.

Toumey, J. W. (1926.) Initial root habit in American trees and its bearing on regeneration. Unpublished MS.

Zon, R. (1927.) Forests and water in the light of scientific investigation. Reprinted from Senate Document No. 469, 62d Congress, 2d Session. 





\section{.}


University of

Connecticut

Libraries 
